\title{
Measuring Malaysian Students Achievement Level in Arabic Morphology: Improving and Developing Curriculum
}

\author{
Yasin Mohamed Yasin M. Sidiq \\ Freelancer of Applied Linguistics Professor \\ California, USA \\ makook2002@yahoo.com \\ Hassan Mohamed Doka* \\ Arabic Islamic Institute in Tokyo \\ Tokyo, Japan \\ dokahassan@yahoo.com \\ Mauidlotun Nisa \\ Universitas Islam Negeri Syarif Hidayatullah \\ Jakarta, Indonesia \\ mauidlotun.nisa@uinjkt.ac.id \\ Kawakib Elnour Osman \\ Language Institute \\ California, USA \\ elfatina2000@hotmail.com
}

\begin{abstract}
This study aimed to identify the level of achievement of Malaysian students in Arabic Morphology material on three areas, previous study period, gender, and student education specialization. This research was a field research conducted on Malaysian students studying Arabic, at the International Islamic University Matriculation Center (IIUMC) in Kuala Lumpur-Malaysia. This study concluded that previous study periods, gender, and education specialization had an important role in this identification that became a reference for the improvement of Arabic Morphology learning curriculum. Students who were first learning Arabic in IIUMC had a high success rate only in matching letters (Anita) with pronouns and fi'il al-madi Shahih, and Mahmuz, and pronouns fi'il almahi al-Mithal. As for those who have studied Arabic for 5 years, 6 years, and 7 years have a high level of ability also in matching letters (Anita) with the pronouns and fi'il al-madi al-ajwaf. The level of ability of male students was lower than female students in all aspects without exception in matching letters (Anita) with pronouns and verbs that begin with the letter Ta'. As for students specializing in Arabic, Sharia, and Humanities, Reveal Knowledge and the Qur'an, and Arabic had different levels of success in accordance with their specialization, such as students with Arabic specialization had a high level of success in all the discussions that had been mentioned, however, for students with other specialties not. From the findings, there are several suggestions, namely communicative approach, gradualism, adoption of the most frequent morphological positions, introduction of grammar through meaning, reconciliation of teaching methods, designing Morphology materials, and exchanging cognitive programs for teachers and students.
\end{abstract}

Keywords: Measurement, achievement level; Malaysian students; Arabic morphology, curriculum Improvement

*Corresponding Author 


\begin{abstract}
Abstrak
Penelitian ini bertujuan untuk mengidentifikasi tingkat keberhalisan mahasiswa Malaysia dalam materi Morfologi Arab pada tiga objek, masa belajar, jenis kelamin, dan spesialisasi pendidikan. Penelitian ini merupakan penelitian lapangan yang dilakukan pada mahasiswa Malaysia yang belajar bahasa Arab, di Pusat Persiapan International Islamic University (PP-IIU) di Kuala Lumpur. Penelitian ini menyimpulkan bahwa masa studi sebelumnya, jenis kelamin, dan spesialisasi pendidikan memiliki peran penting dalam keberhasilan sehingga menjadi acuan perbaikan kurikum Morfologi Arab. Mahasiswa yang baru pertama kali belajar bahasa Arab di PP-IIU memiliki tingkat keberhasilan tinggi hanya dalam mencocokkan huruf (Anita) dengan kata ganti dan fi'il al-madi Sahih dan Mahmuz. dan kata ganti fi'il al-madi al-Mithal. Ada pun yang telah belajar bahasa Arab selama 5 - 7 tahun memiliki tingkat kemampuan tinggi juga dalam mencocokkan huruf (Anita) dengan kata ganti fi'il al-madi al-ajwaf. Tingkat kemampuan mahasiswa laki-laki lebih rendah daripada perempuan dalam semua aspek tanpa terkecuali dalam mencocokkan huruf (Anita) dengan kata ganti dan kata kerja yang diawali dengan huruf Ta'. Adapun mahasiswa dengan spesialisasi bahasa Arab, Syariah, dan ilmu Humaniora, Ilmu Irfan dan Alquran, dan bahasa Arab memiliki tingkat keberhasilan yang berbeda sesuai dengan spesialisasinya, seperti mahasiswa dengan spesialisasi bahasa Arab memiliki tingkat keberhasilan yang tinggi dalam semua pembahasan, akan tetapi bagi mahasiswa dengan spesialisasi lain tidak. Ada beberapa saran yang perlu diperhatikan, seperti pendekatan komunikatif, gradualisme, adopsi posisi morfologis yang paling sering, pengenalan tata bahasa melalui makna, dan rekonsiliasi metode pengajaran.
\end{abstract}

Kata Kunci: Pengukuran; tingkat keberhasilan; mahasiswa Malaysia; morfologi Arab, perbaikan; Kurikulum

\title{
الملخص
}

يهدف البحث إلى تشخيص مستويات الطلاب الماليزيين التَّحصيلية في قواعد الصرف التهرف العربي

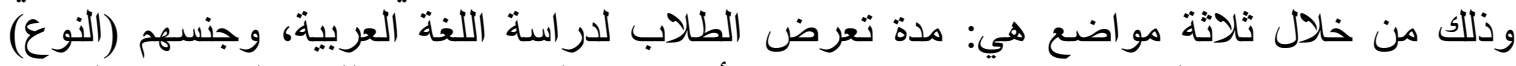

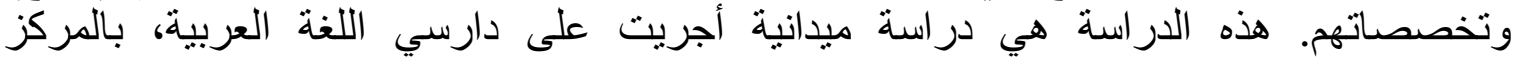

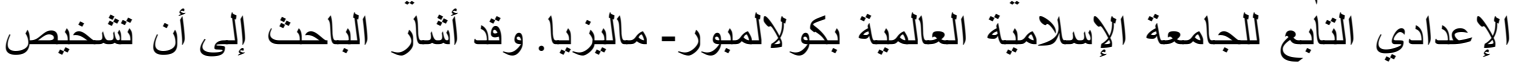

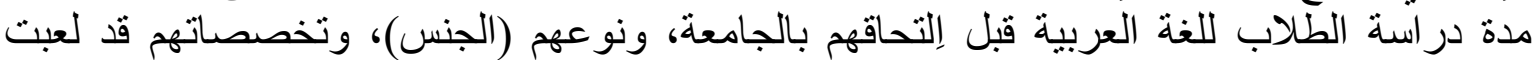

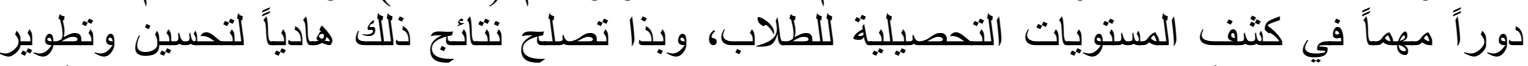

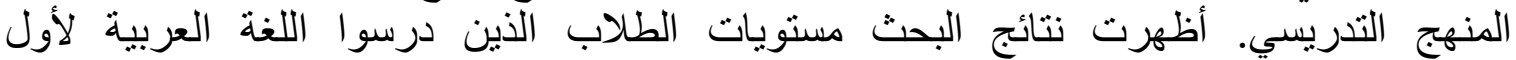

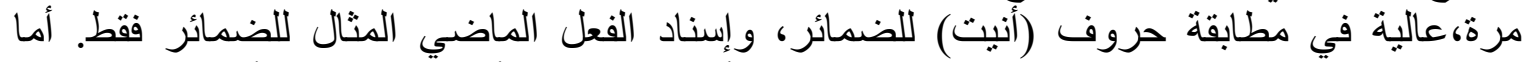

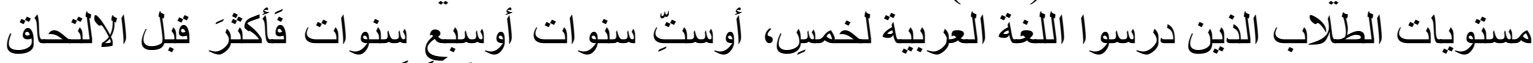

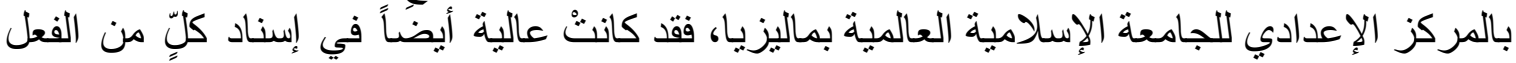

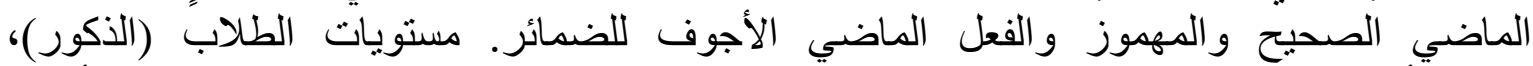
جاءت أقل من مسنويات الطالبات (الإناث) في كل المتغيرات ما عدا مطابقة حروف (أنيت)

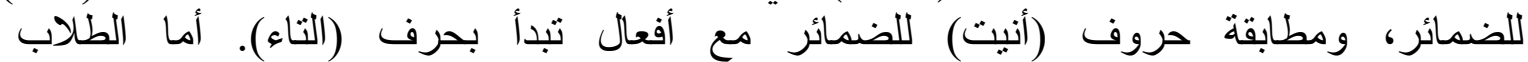

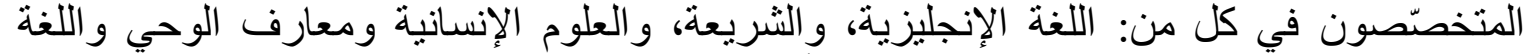

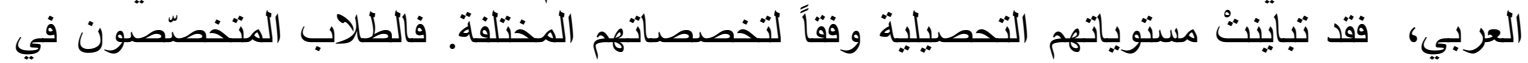

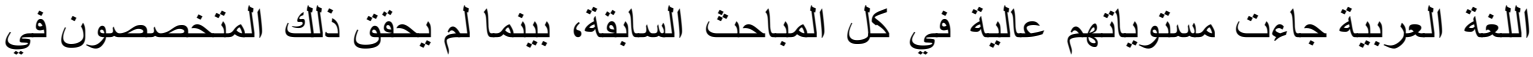

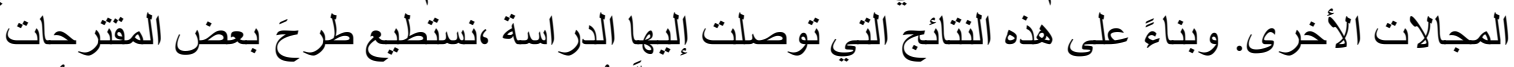

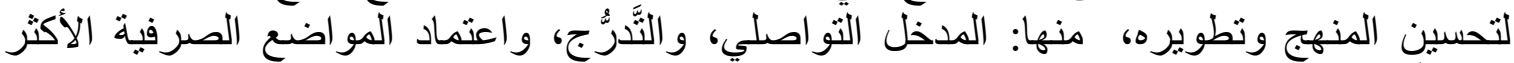

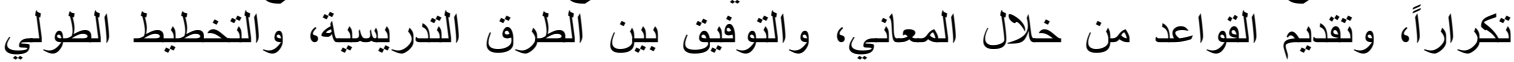

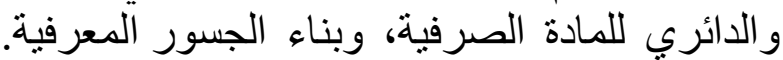
الكلمات الرئيسية :القياس؛ المسنوى التحصيلي؛ الطلاب الماليزيون؛ قو اعد الصرف العربي؛ 


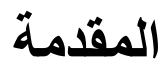

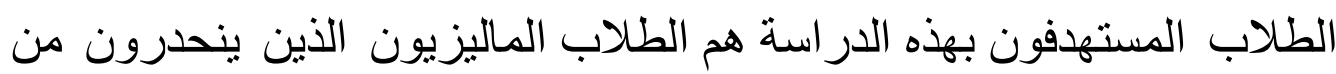

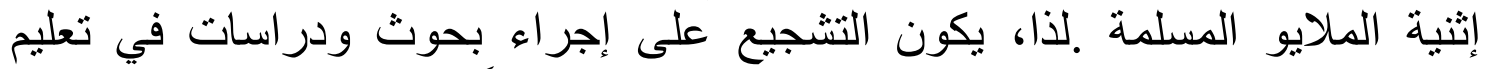
اللغة العربية خاصة في علم النحو والصرف مهماً لتحسين المناهج ألدراسية

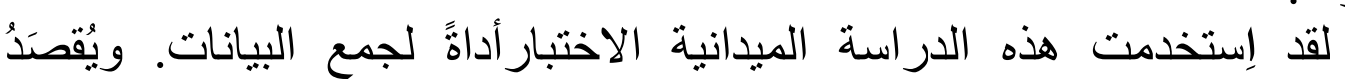
وتطوير ها.

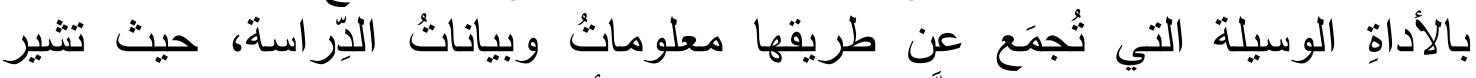

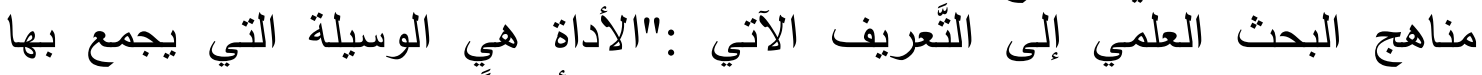

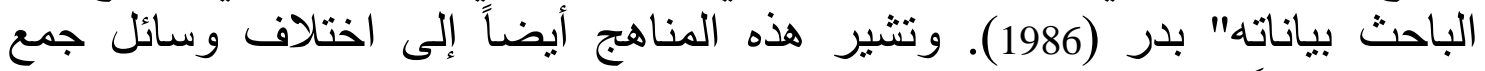

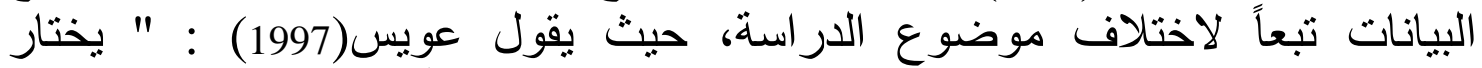

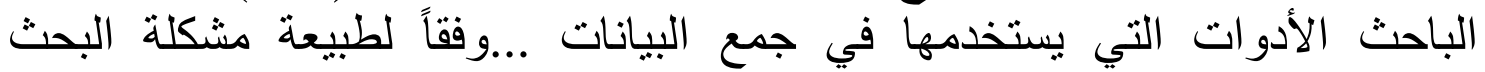

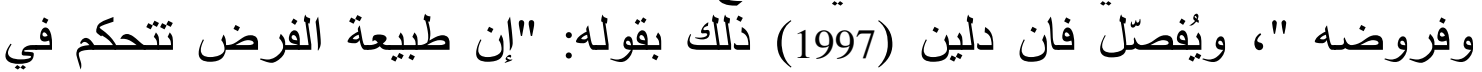

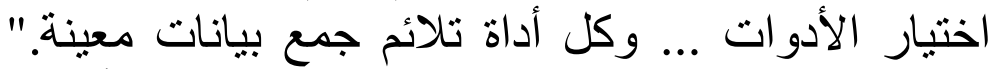

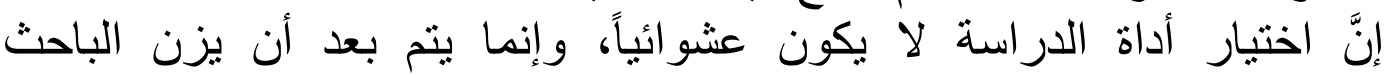

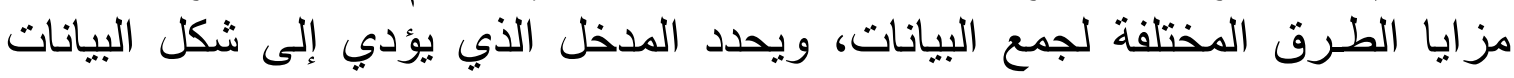
اللازمة ونو عها لاختبار صدق الطن فرضه لئه

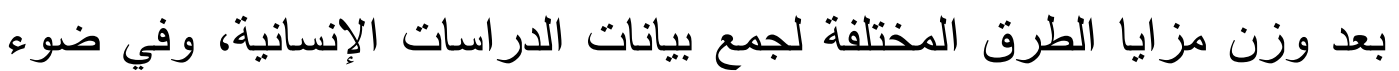

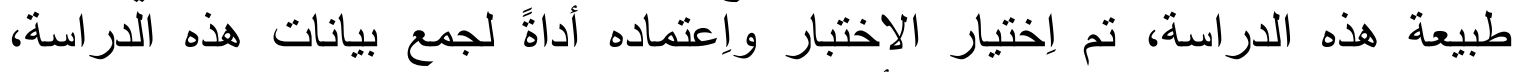

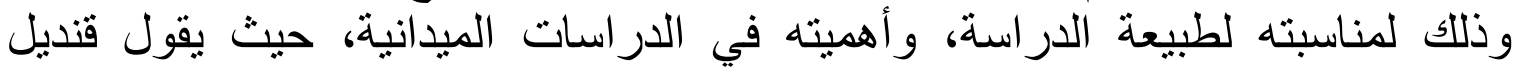

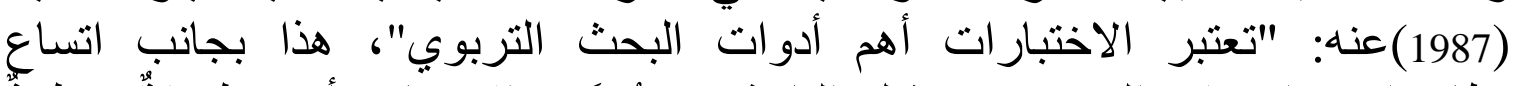

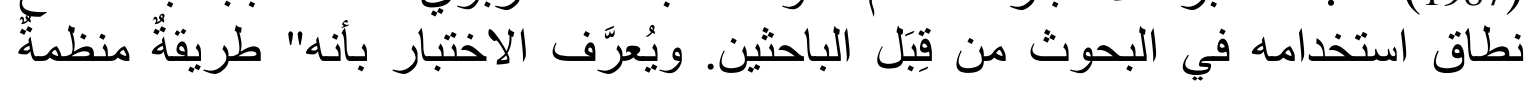

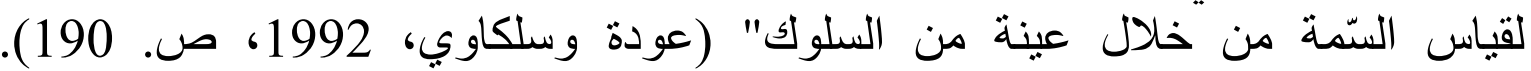

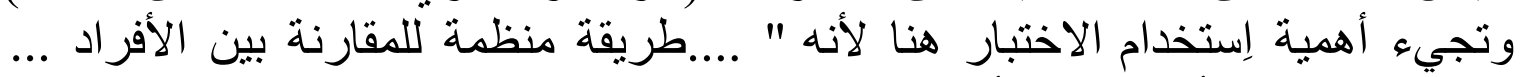

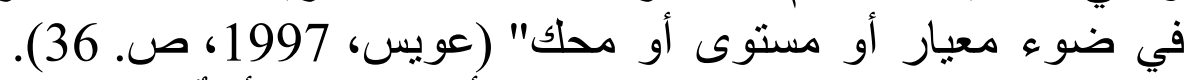

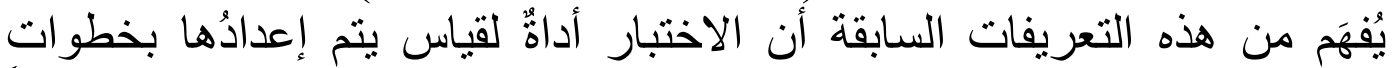

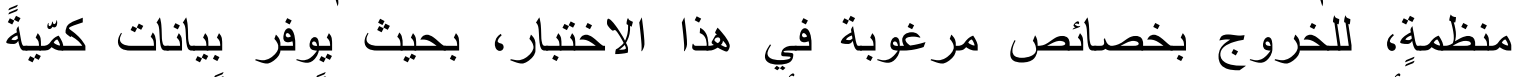

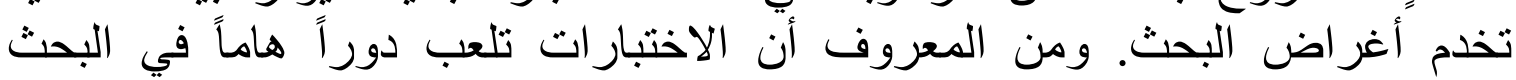

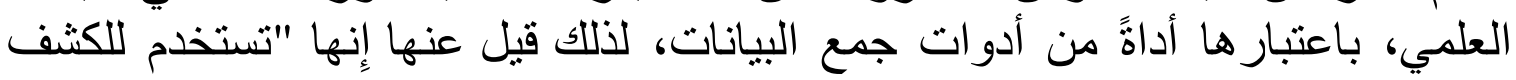

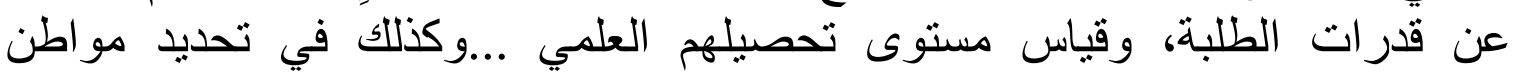

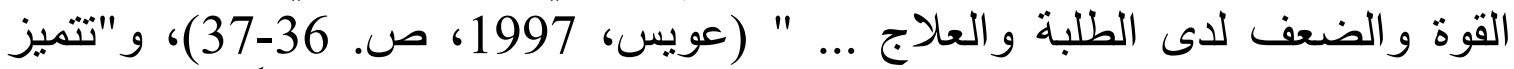

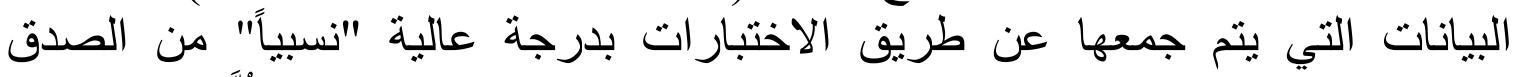

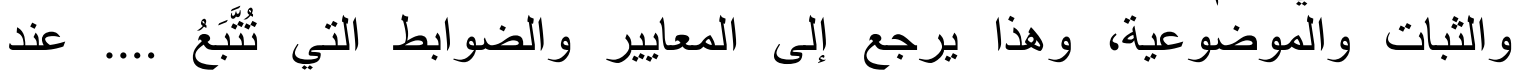

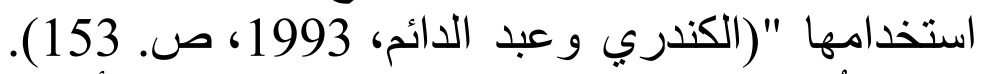

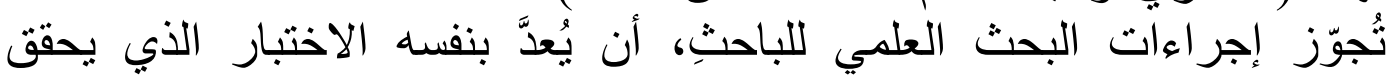

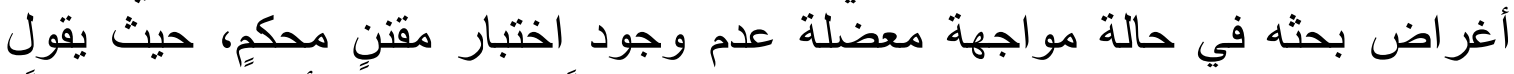

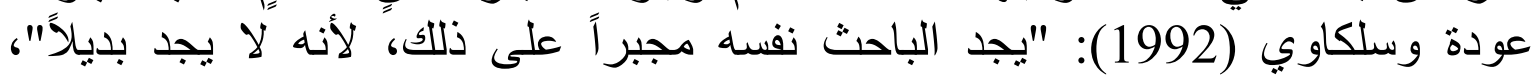

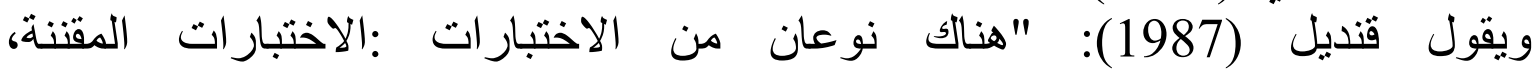




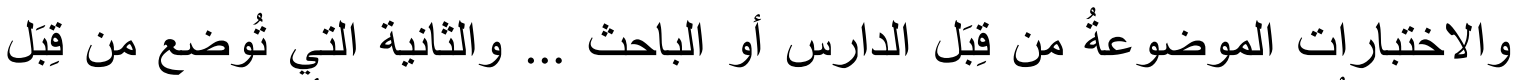

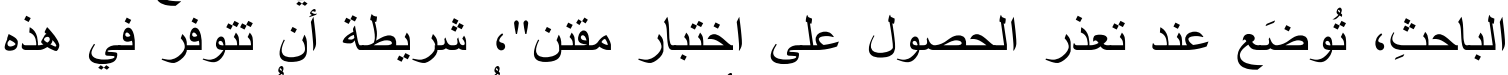

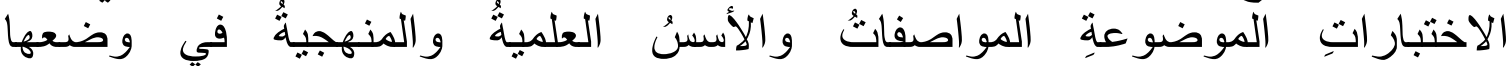

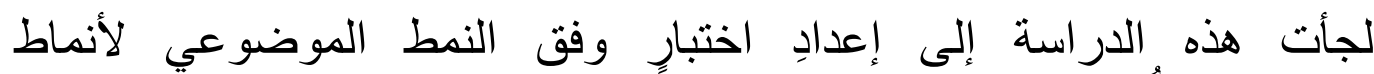

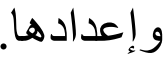

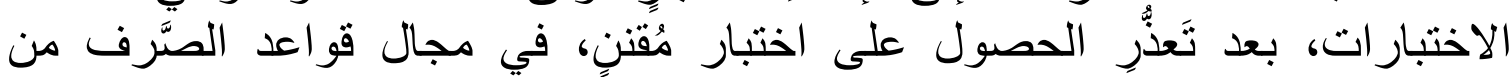

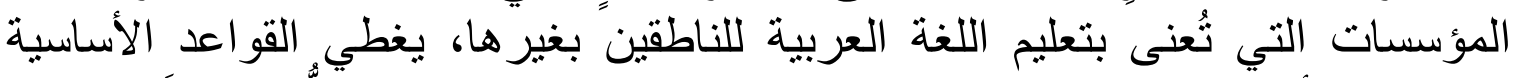

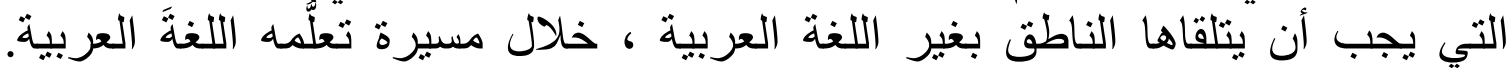

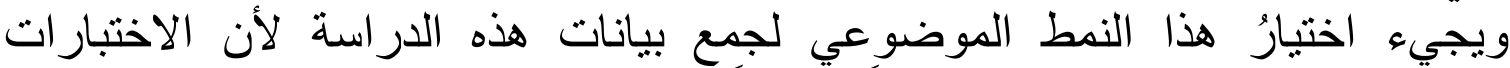

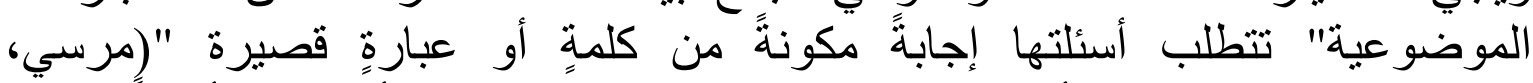

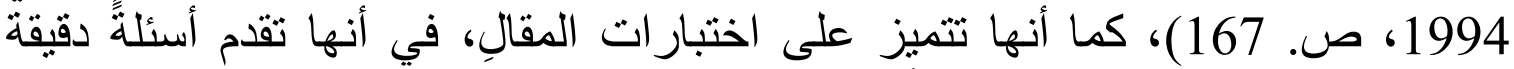

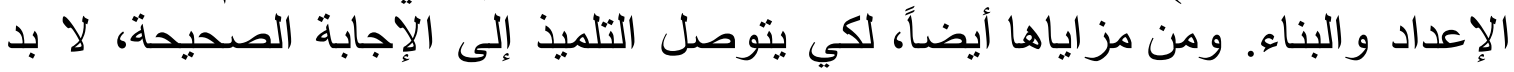

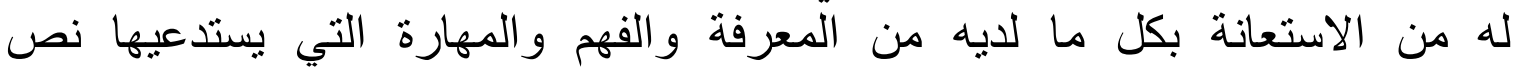

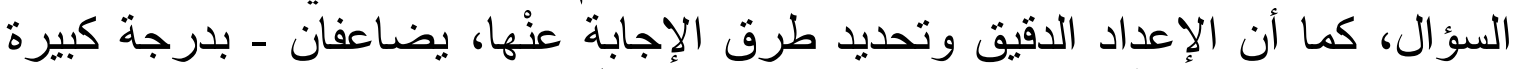

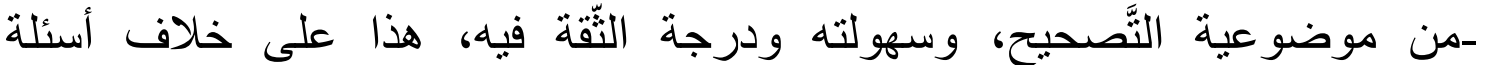

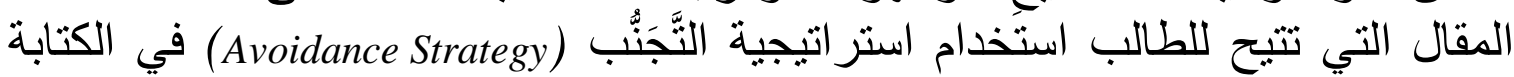

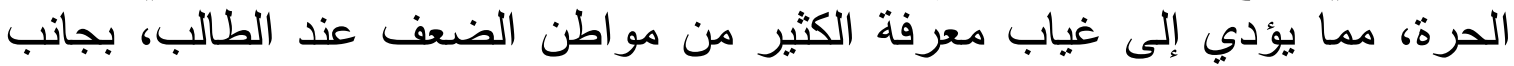

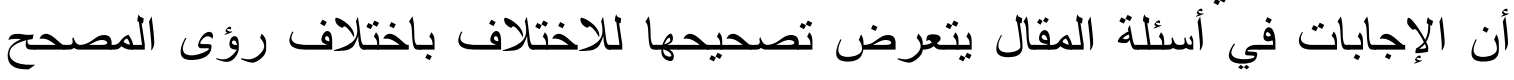

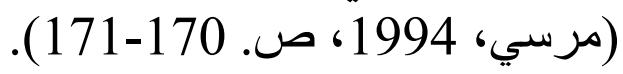

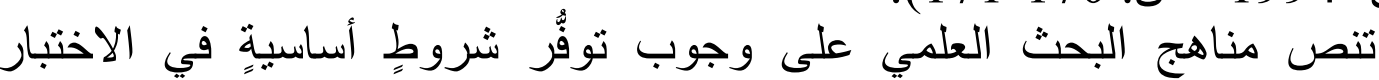

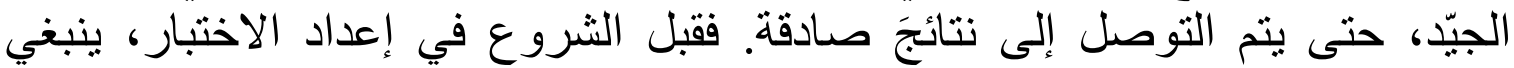

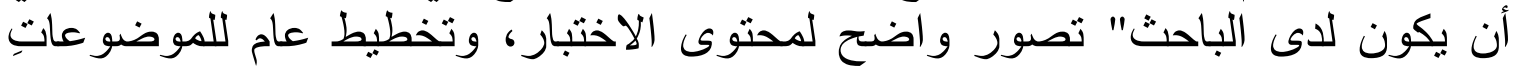

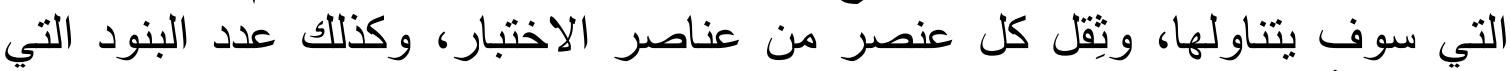

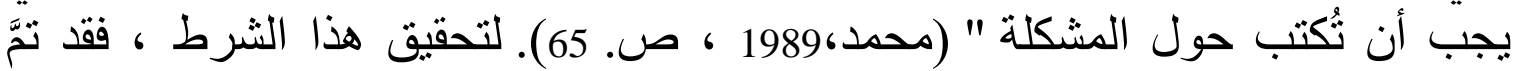

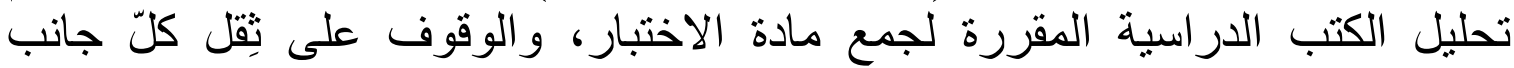

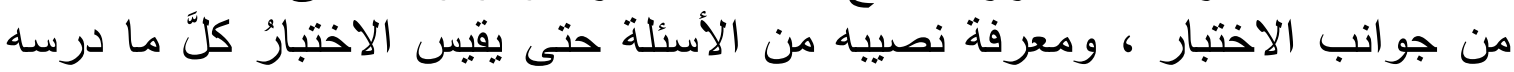

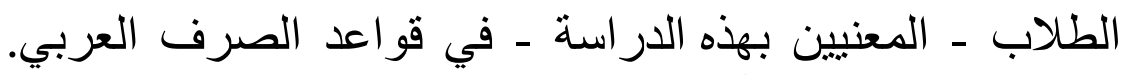

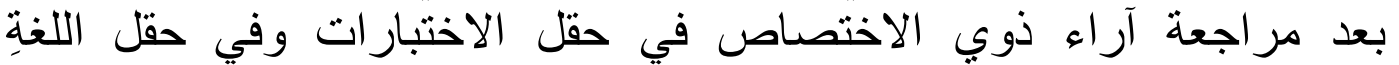

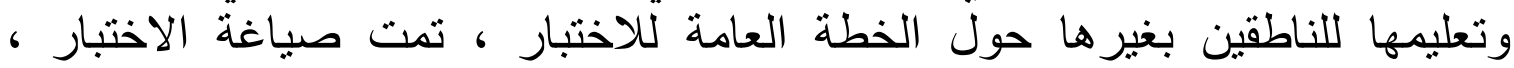

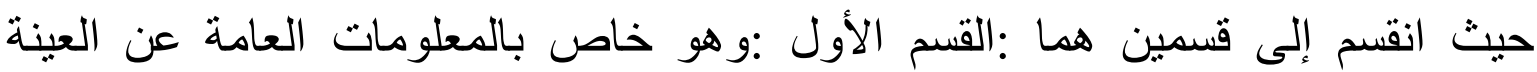
المفحوصة، والقسم الثاني :مُتعلق بالأسئلة.

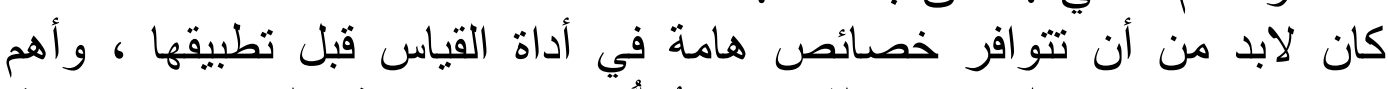

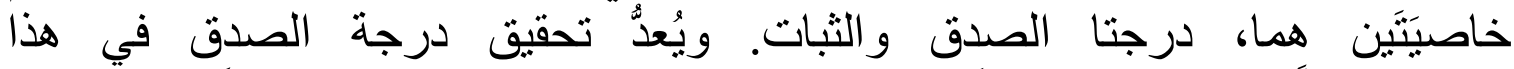

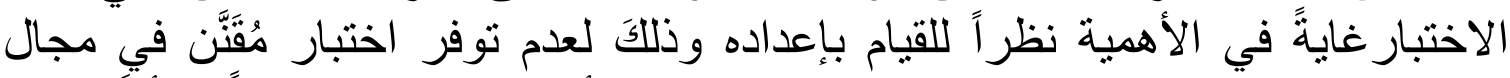

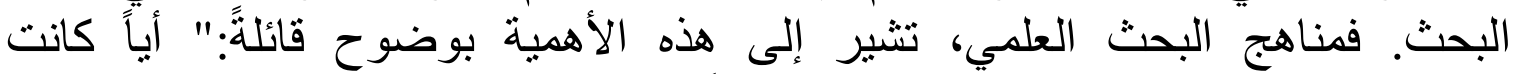

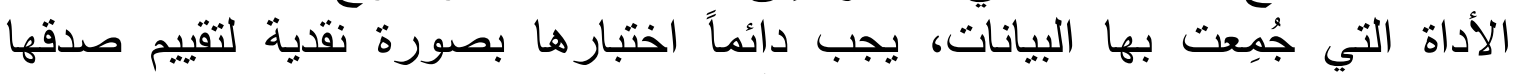

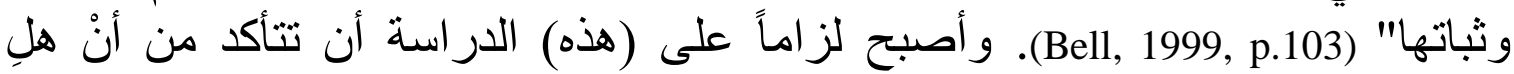




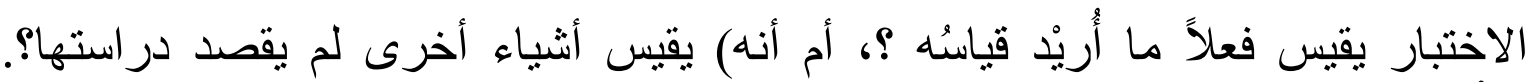

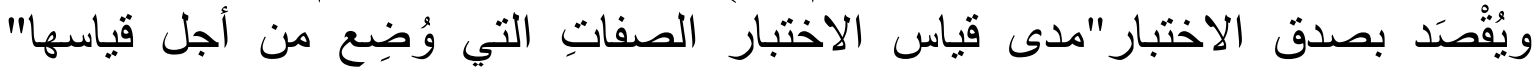

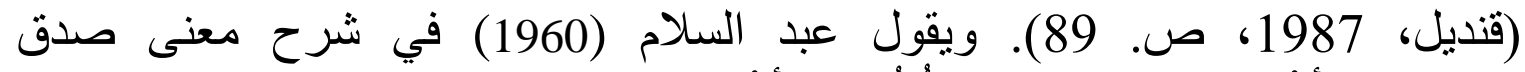

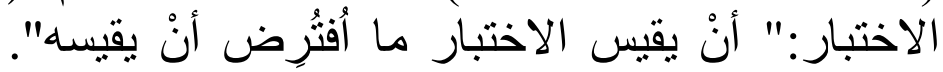

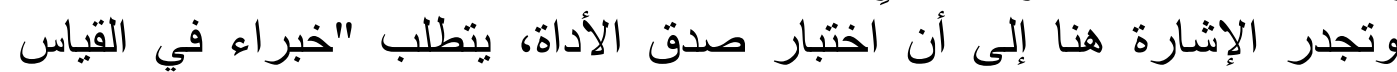

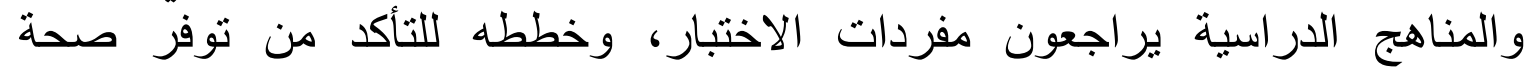

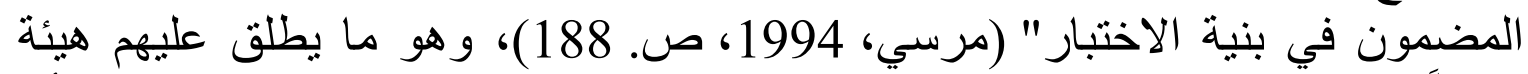

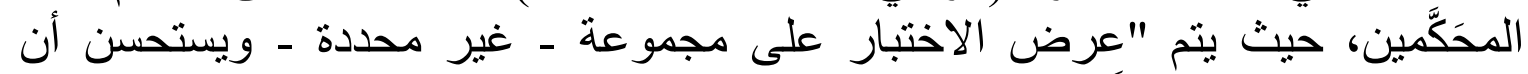

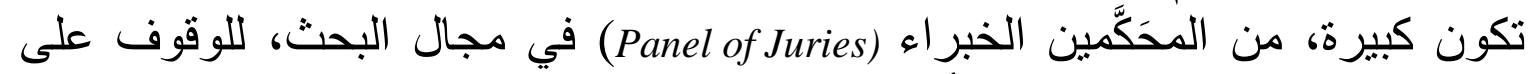

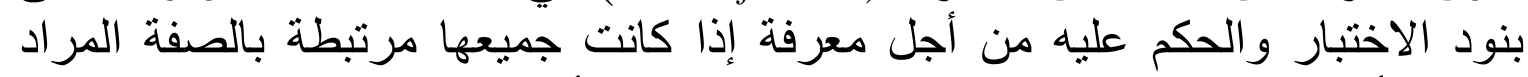

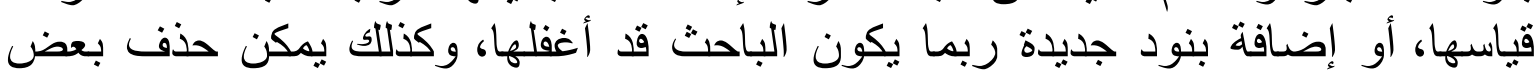

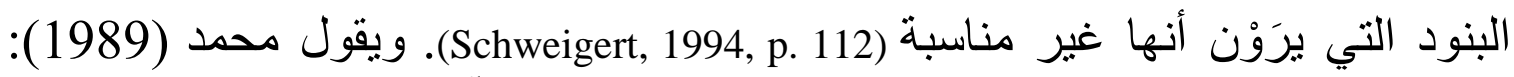

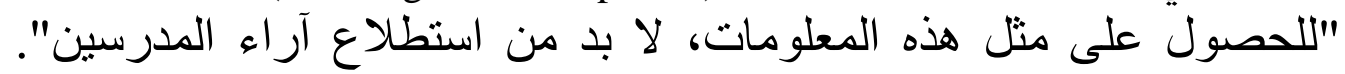

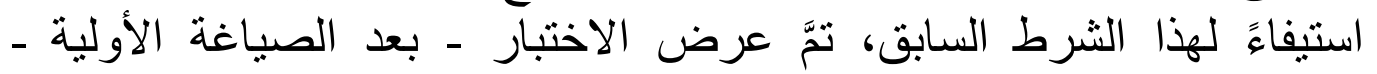

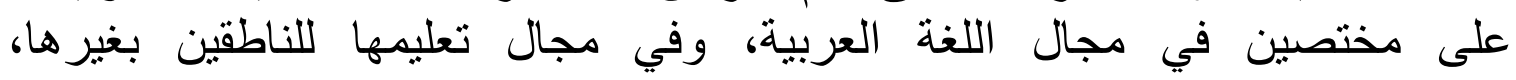

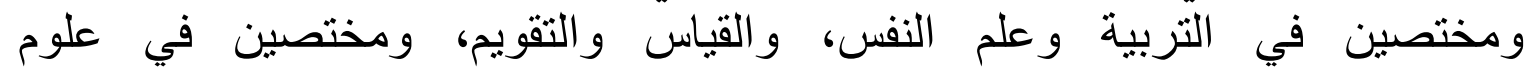

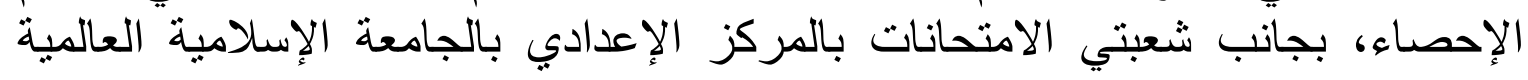

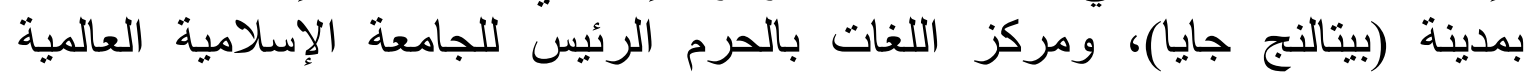
لقد كان الغرض من هذا هذا العَزض هو فحص محتوى الاختبار وعناصره،

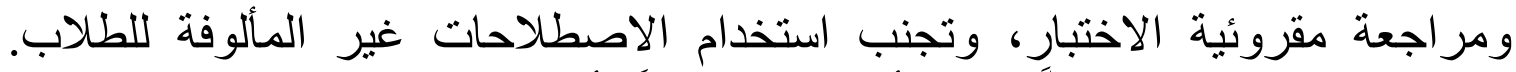

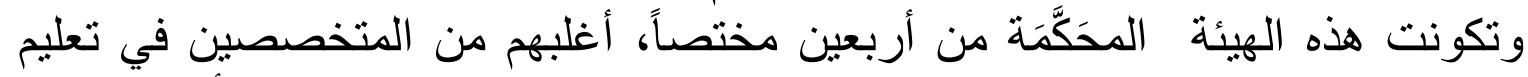

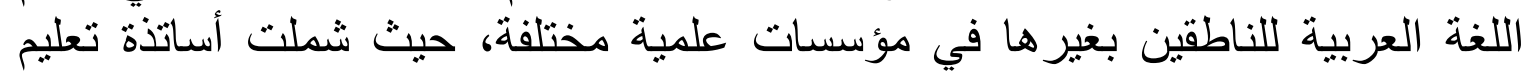

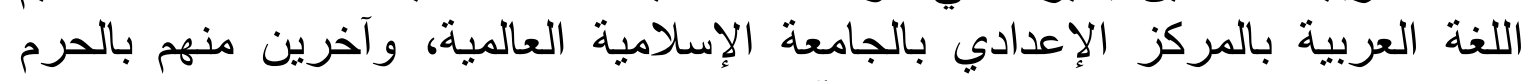

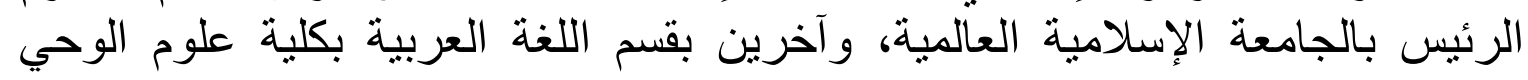

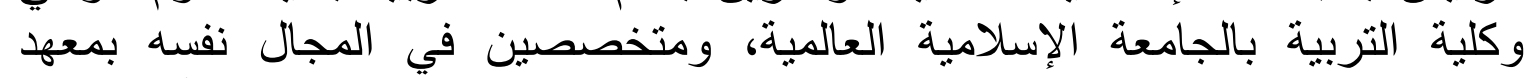

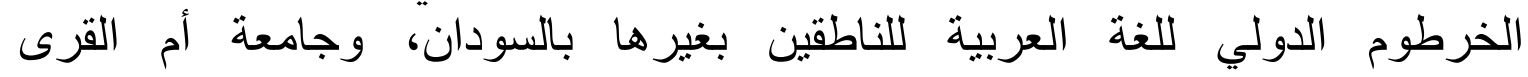

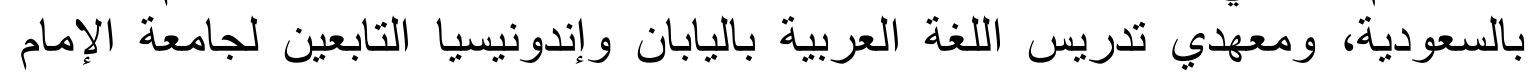

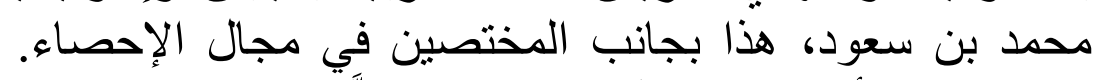

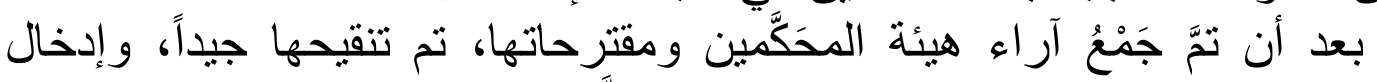

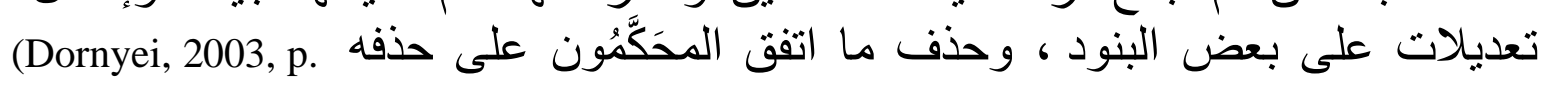

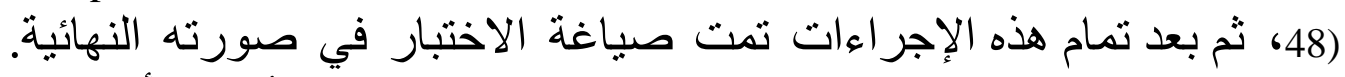

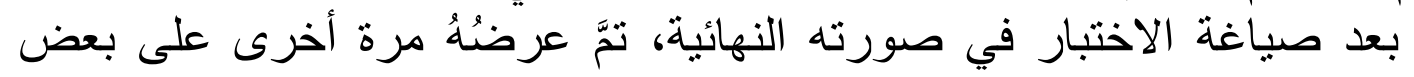

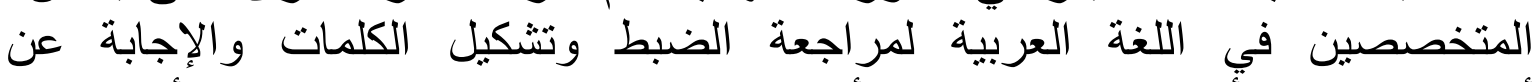

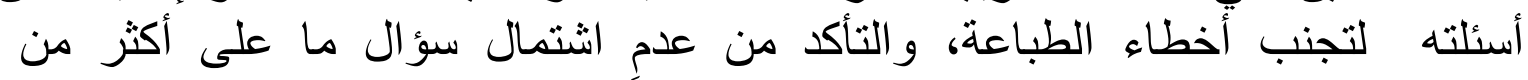

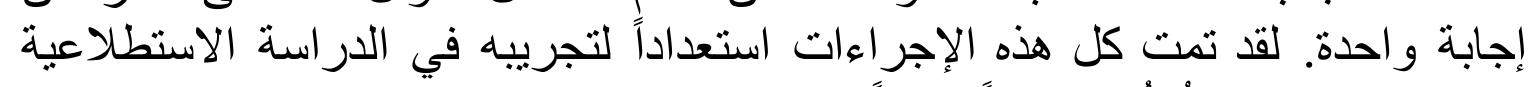
Pilot Study 
البحث العلمي بلفظ الوجوب قائلة: "يجب اختبار أداة جمع البيانات (Pilot Study)

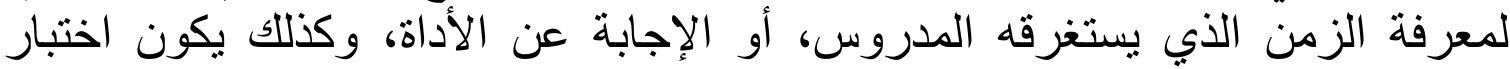

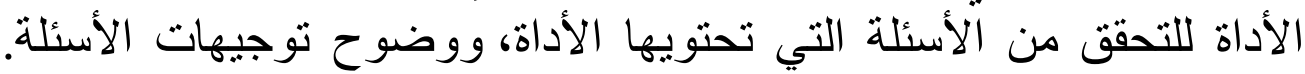

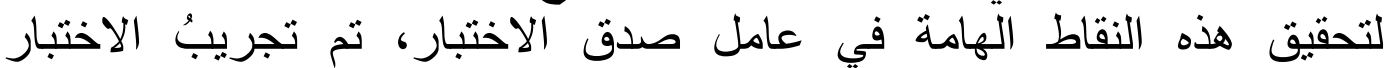

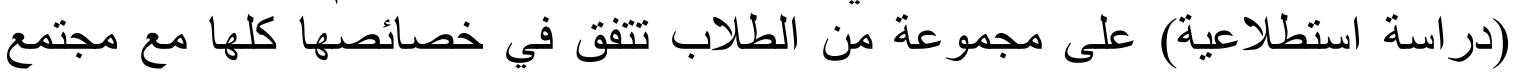

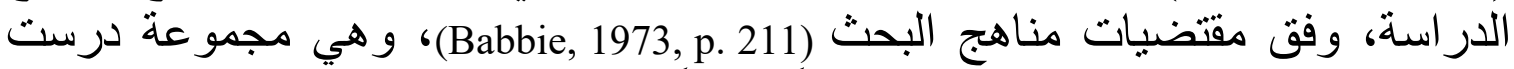

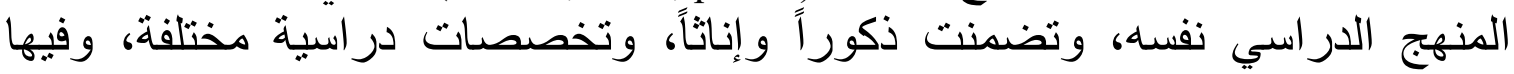
من درس اللغة العربية قبل الالتحاق بالمركز الإعدادي بالجامعة الإلية الإسلامية العالمية،

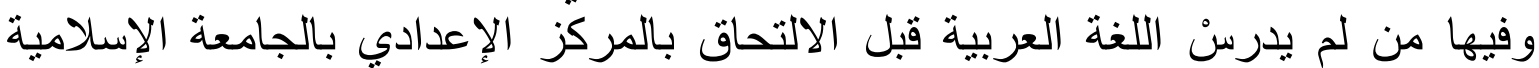

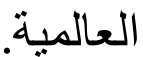

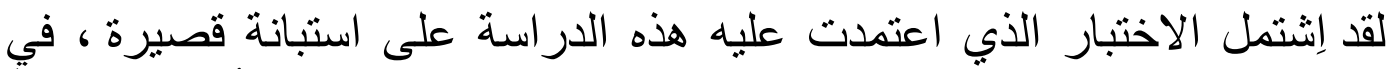

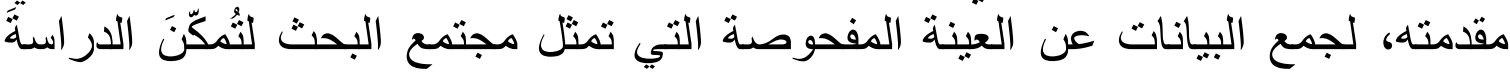

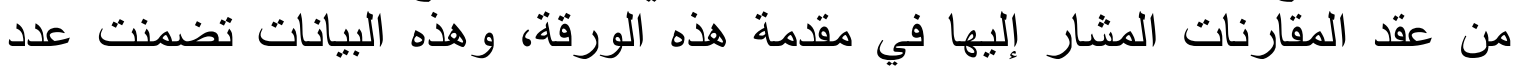

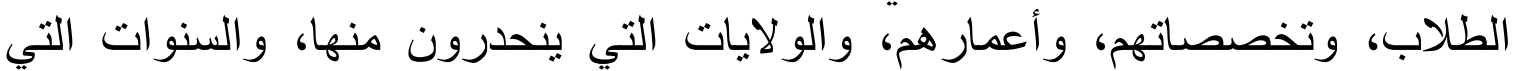

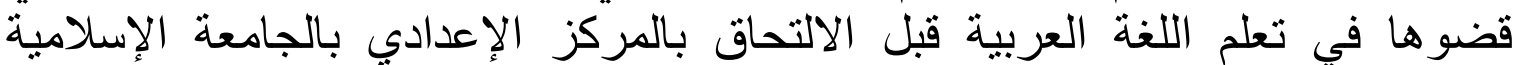

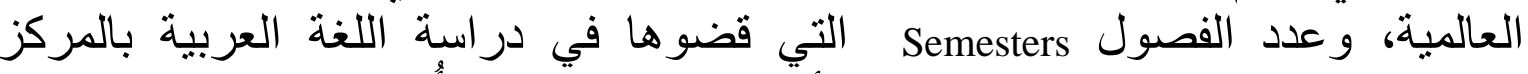

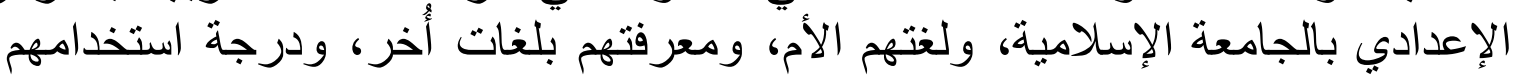

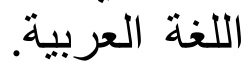

لقد تضمن الاختبار مائتين وأربعة أسئلة (204) في قوراعد الصرف العربي،

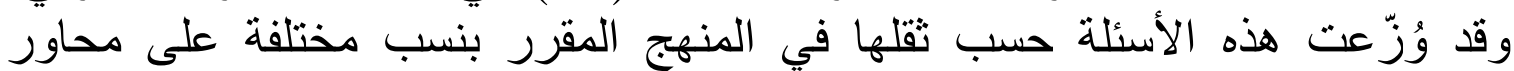

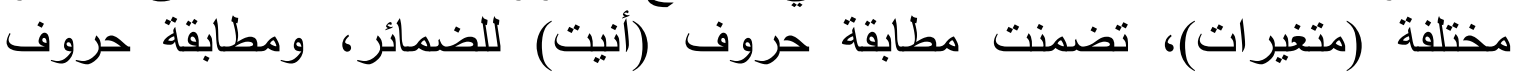

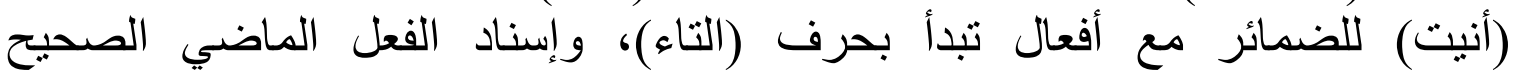

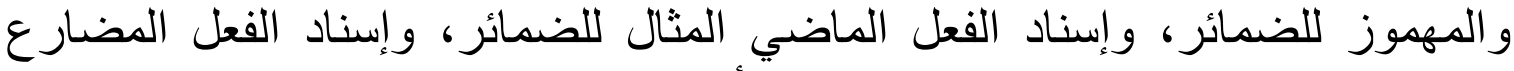

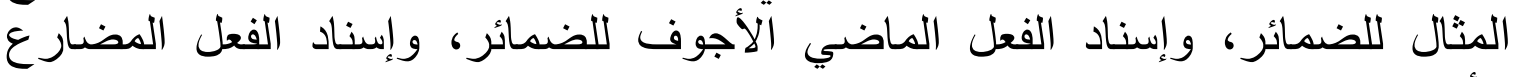

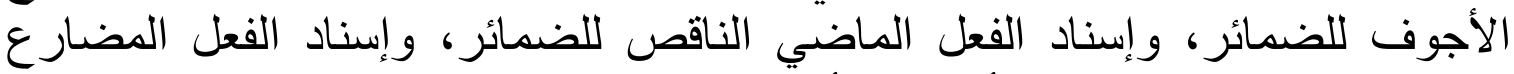

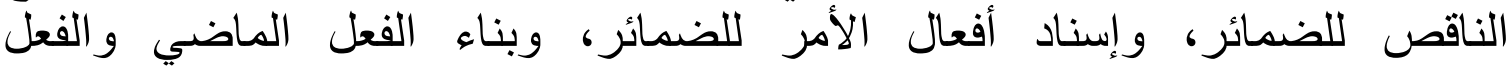

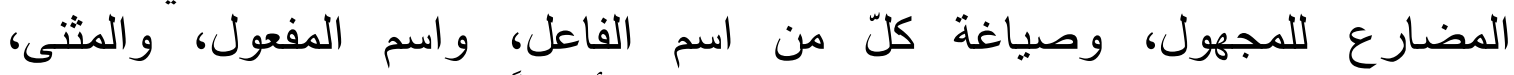
و المصادر (بنوعيها)، واسم التفضيل، و الجموع، وأخير اً مو اضع العلة.

\section{المنهج}

هذا البحثُ ميدانيٌ أجري على الطلاب الماليزيين دارسي اللغة العابِ العربية،

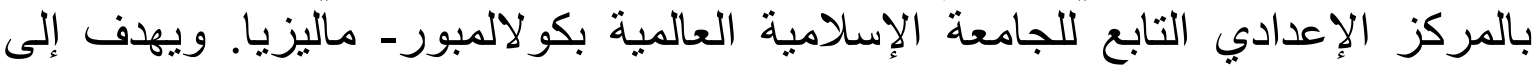

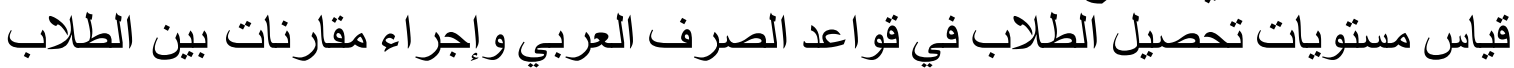

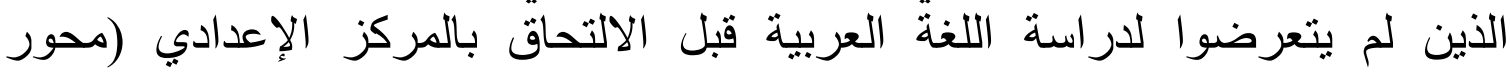

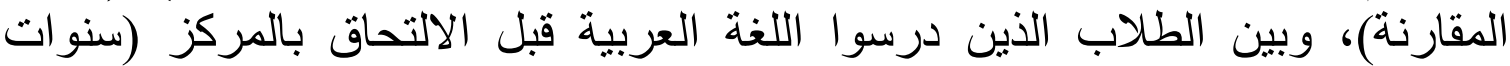

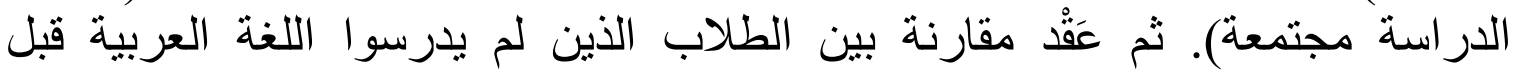
الالتحاق بالمركز الإعدادي، وبين الطلاب الذين درسوا اللغة العربية قبل الإنية التحاق 


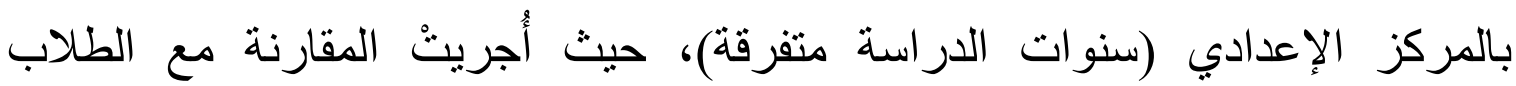

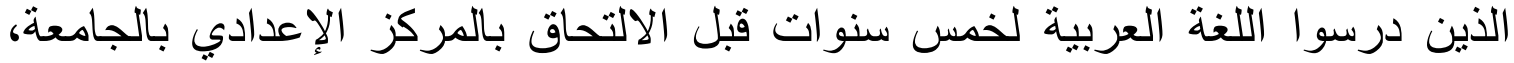
ومع الطلاب الذين درسوا اللغة العربية لست سنوات، ومع الطلاب الذين الذين درسوا اللغة العربية لسبع سنوات أو أكثر.

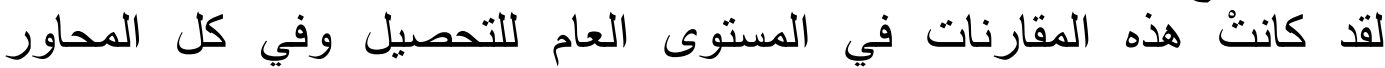
الصرفية المختلفة، وكذلك نمَّت المقارنة بين الطلاب من حيث الجنس (النوع) في

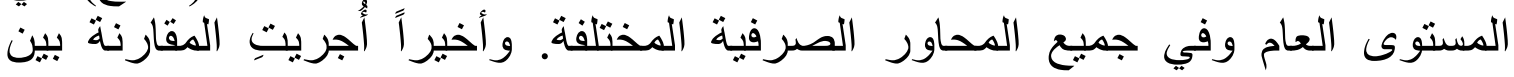
الطلاب من حيث التخصصات المختلفة وكان الطلاب المتخصصون في اللغة العربية هم محور المقارنة، وذللك على المستوى العام و المحاور الصرفية المختلفة.

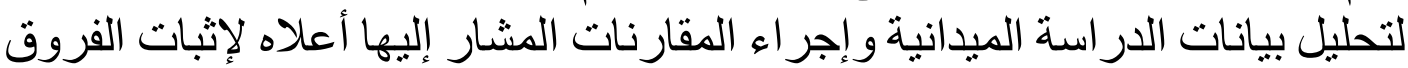
ذات الدلالة الإحصائية (إن وجدت) وفق القيم الإحتمالية (0.05)، ثم استخدام البرنامج

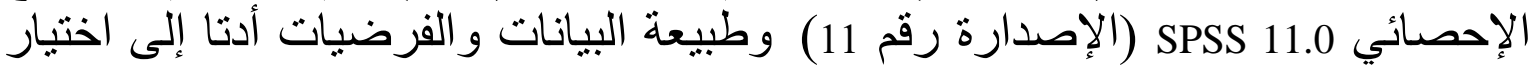
اختبارين للتحليل الدقيق هما: إختبار ANOVA و إختبار

\section{نتائج الاراسة ومناقشتها}

مستوى الطلاب في المواضع الفرعية

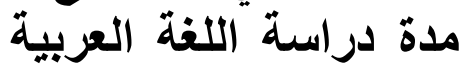

مستوى الطلاب الذين درسوا اللغة العربية لأوله الهاه مرة جاءت مستويات الطلاب الذين درسوا اللغة العربية في المركز الإعدادي دري الإبه بالجامعة الإسلامية العالمية لأول مرةٍ عاليةً في موضعين اثنين هما :مطابقة حروف

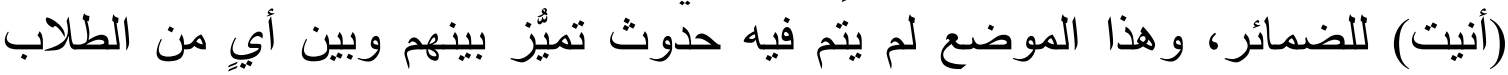

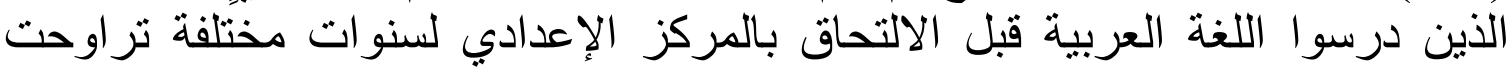

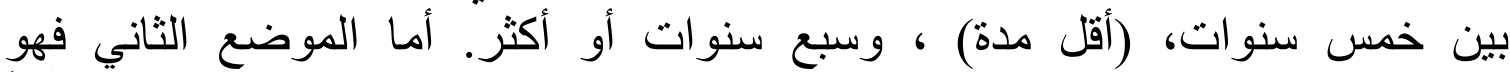

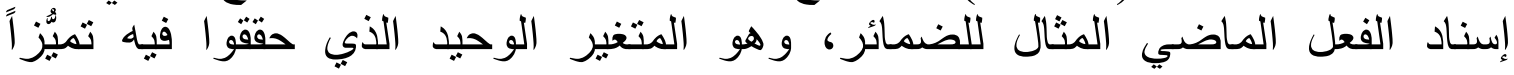

على الطلاب الذين درسوا اللغة العربية لمدة خمس سنوات (قيمة احتمالية 0.023 ). لقد جاءت مستويات هؤلاء الطلاب الذين لم يدرسوا اللغة العربية قبل فئل

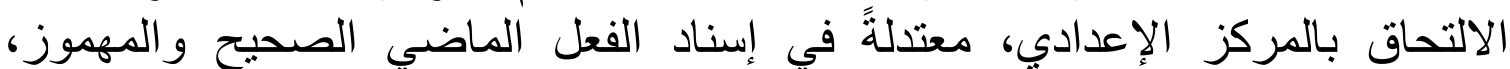
و الفعل الماضي الأجوف للضمائر، وفوق الوسط في في مطابقة حروف (أنيت)

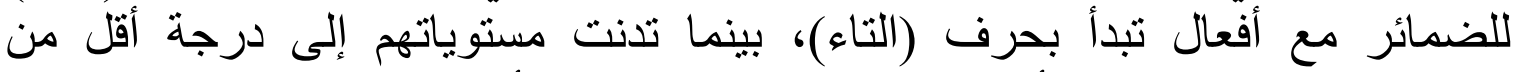
الوسط في المتغيرات الأخرى، بل كانت مستوياتهم أقل المستويات عند مقارنتهم

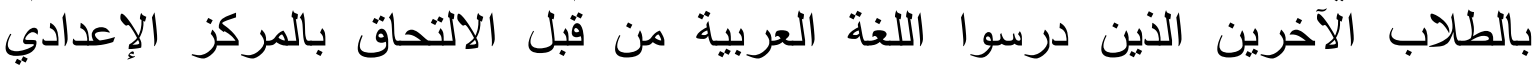

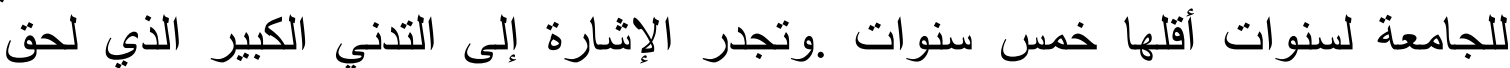
بمستويات هؤلاء الطلاب في كلٍ من إسناد الفعل المضارع المثنال للضمائر، وبناء

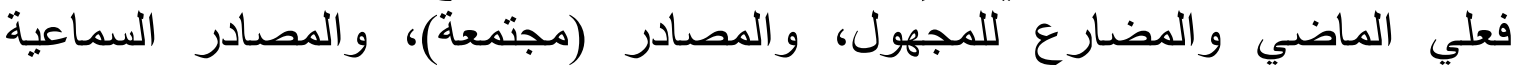
و القياسية، وصياغة الجموع، وصياغة اسمي المفعول والتفضيل، ومواضع العلة. 


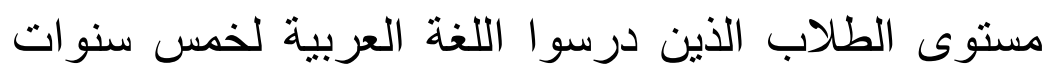

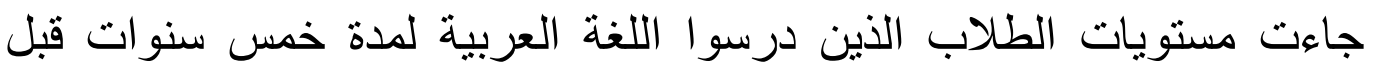

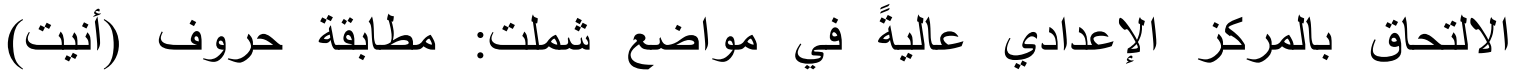

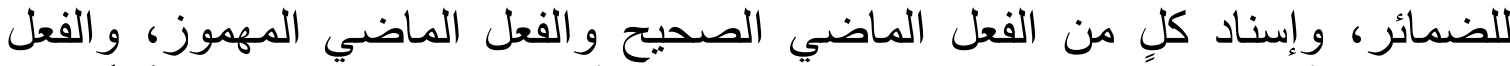

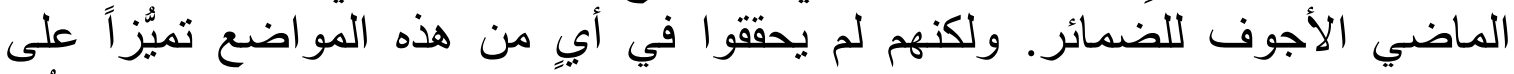

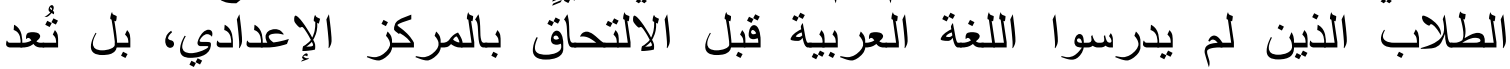

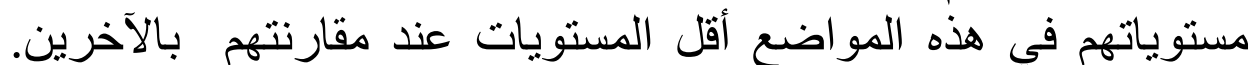

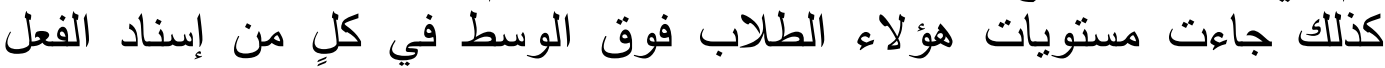

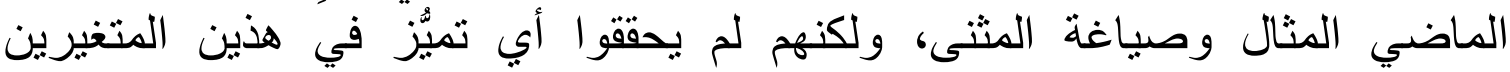

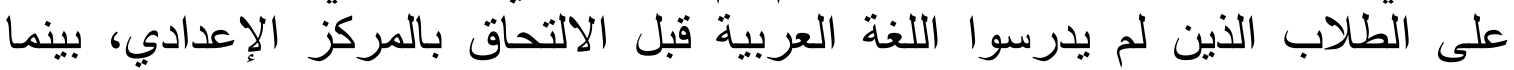

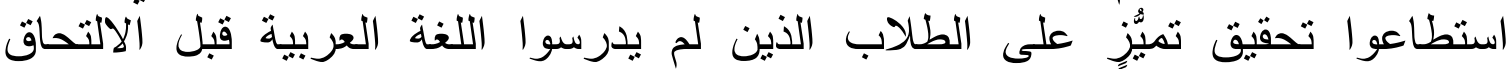

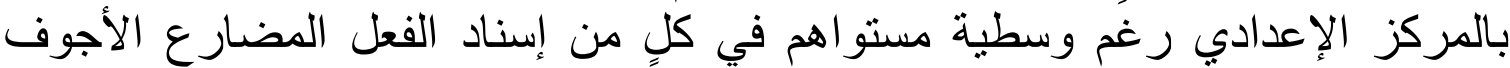

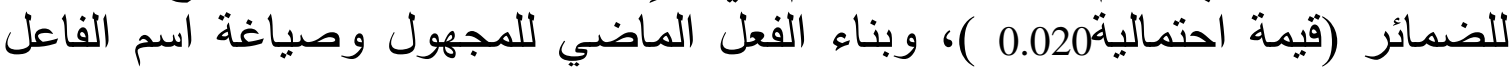

$$
\text { (قيمة احتمالية } 0.000 \text { صفر ). }
$$

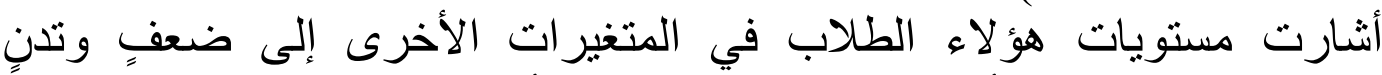

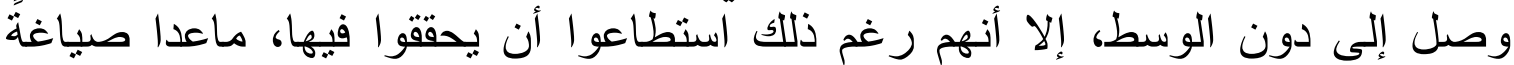

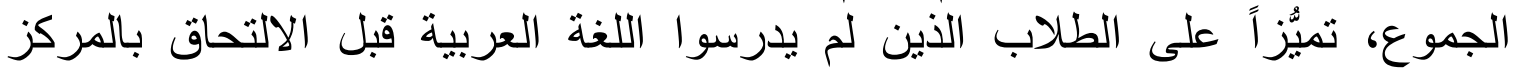

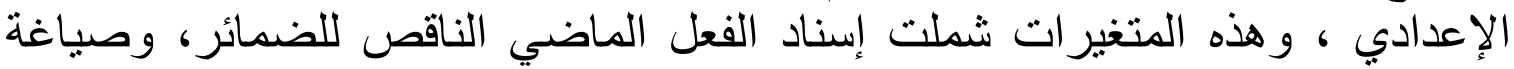

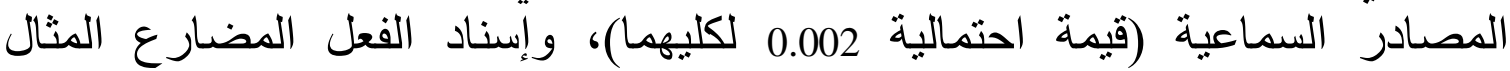
للضمائر (قيمة احتمالية الفية

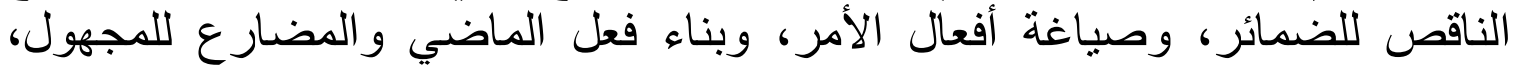

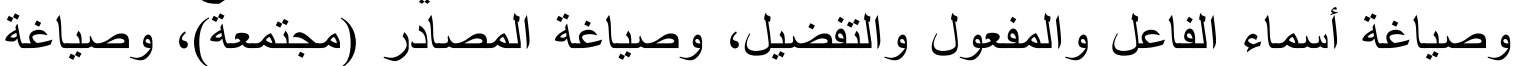

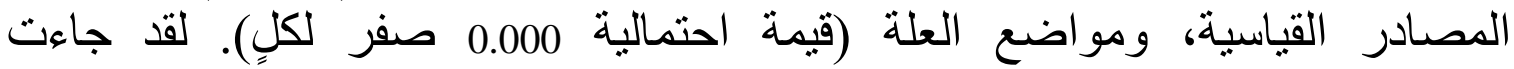

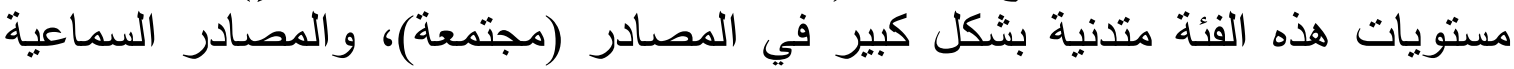
و القياسية، وصياغة اسم التفضيل، و الجموع.

\section{مستوى الطلاب الذين درسوا اللغة العربية لستِ سنوات}

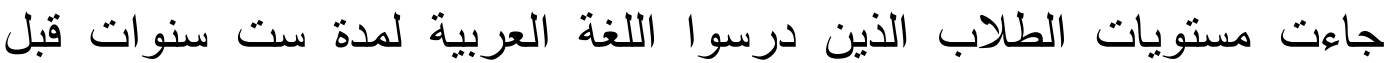

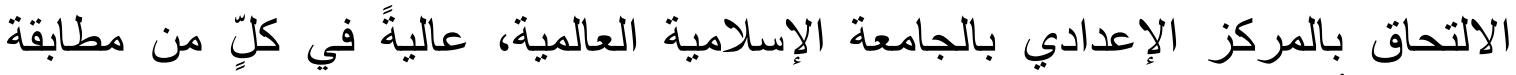

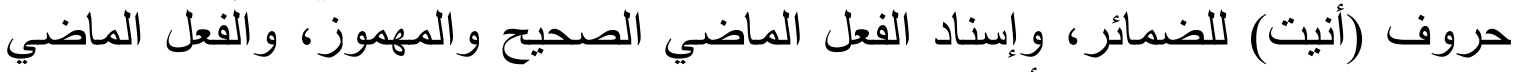

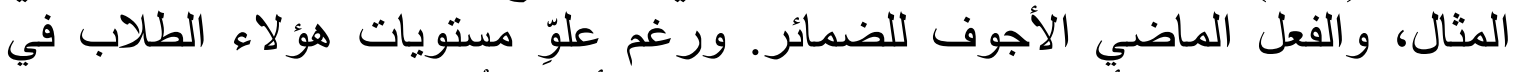

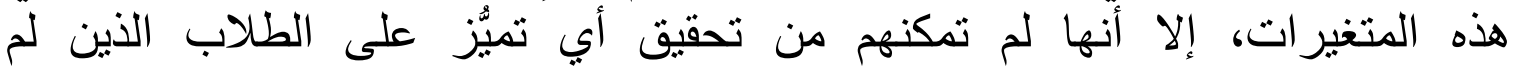

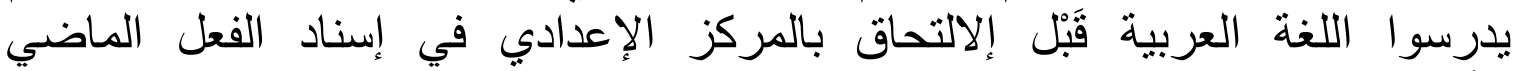

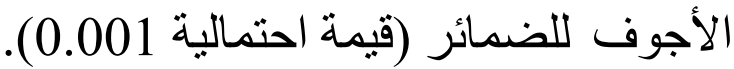

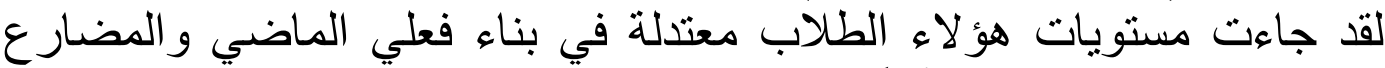

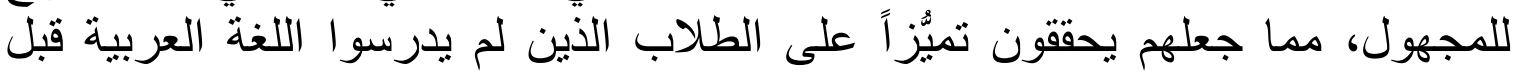


الالتحاق بالمركز الإعدادي في كليهما (قيمة احتمالية 0.000 صفر)، كما جاءت الإت وصياتر

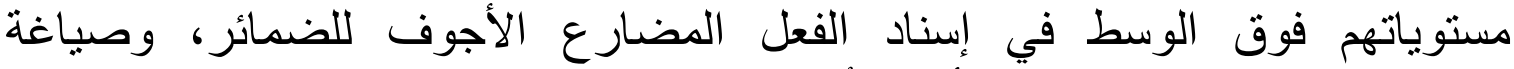

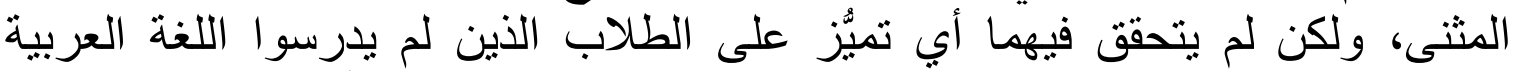

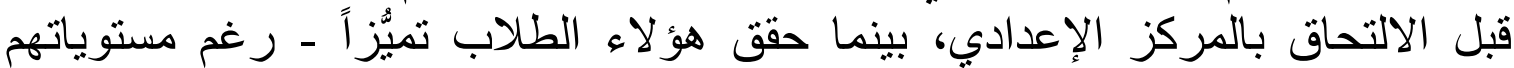

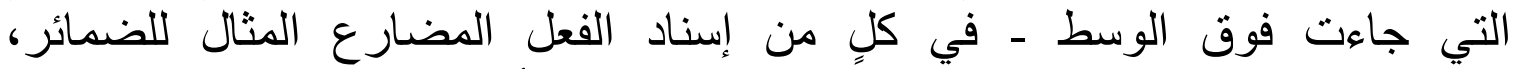

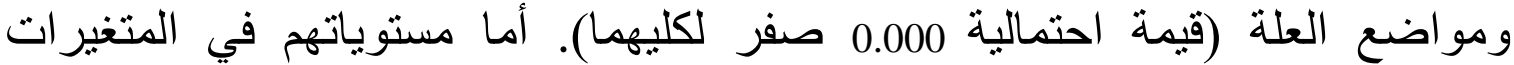

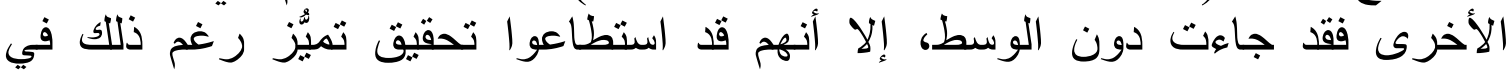

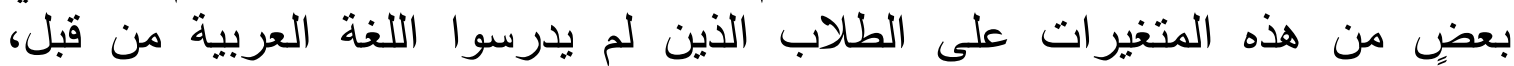

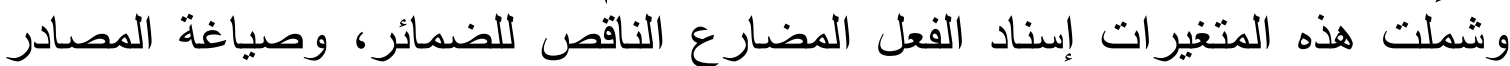

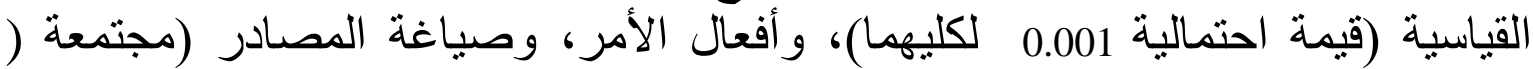

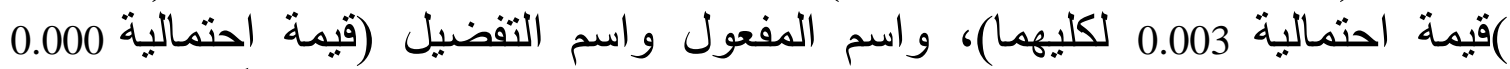

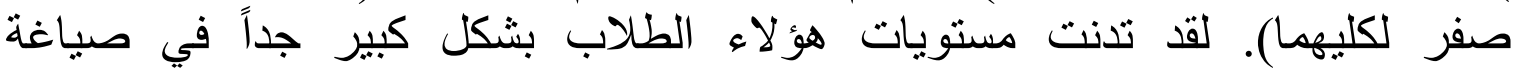
المصادر (مجتمعة)، و المصادر السماعية والقياسية، واسم التفضيل والجموع.

مستوى الطلاب الذين درسوا اللغة العربية لسبع سنوات أو أكثر

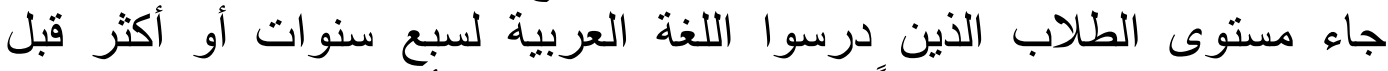

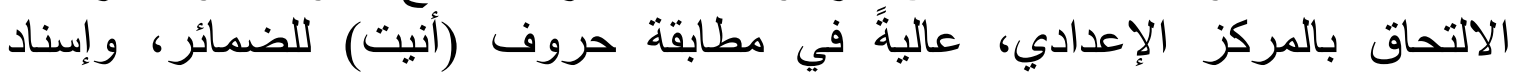

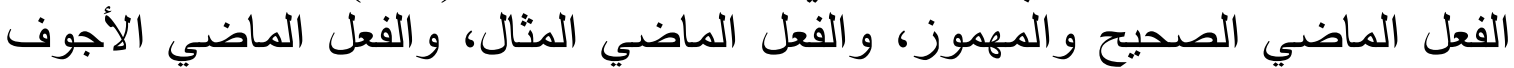

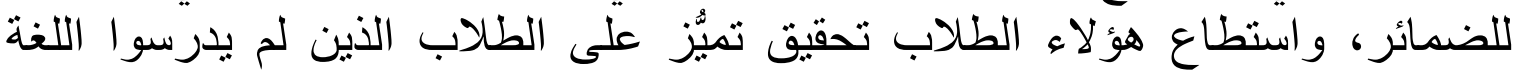

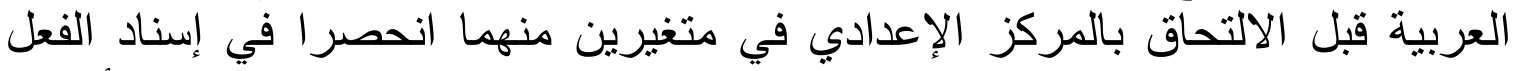

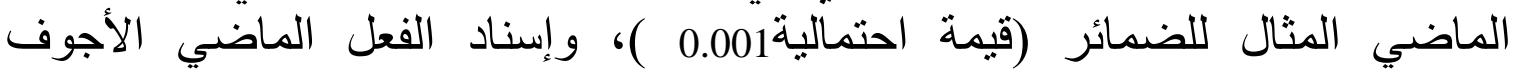
للضمائر (قيمة احتمالية

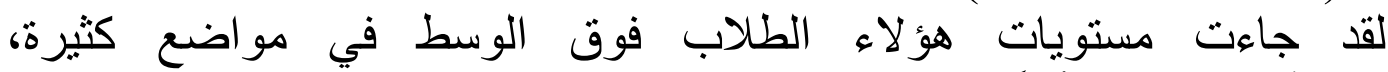

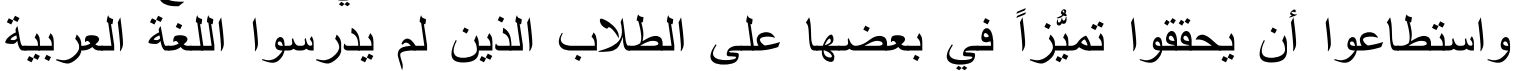

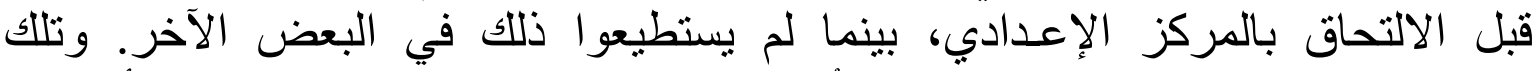

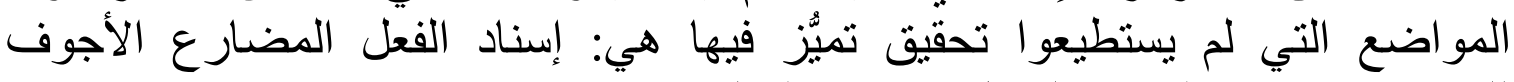

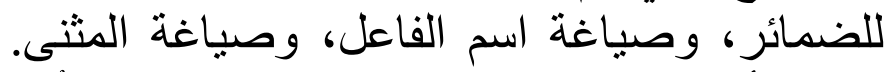

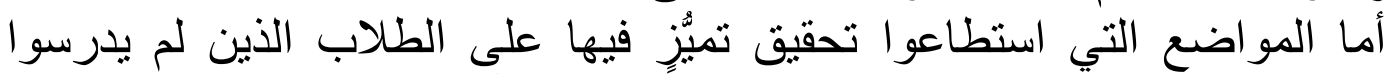

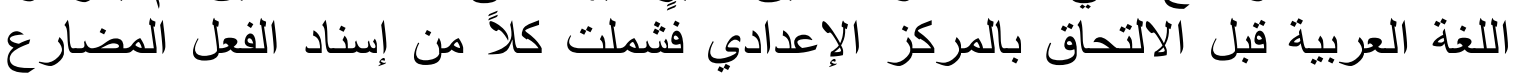

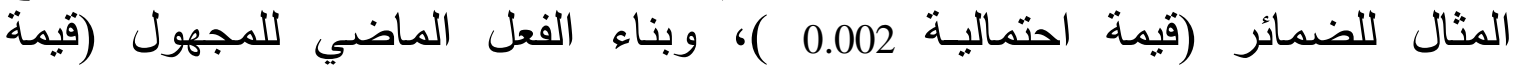

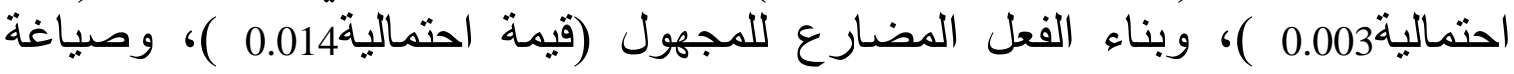
اسم المفعول (قيمة احتمالية 0.000 ) ).

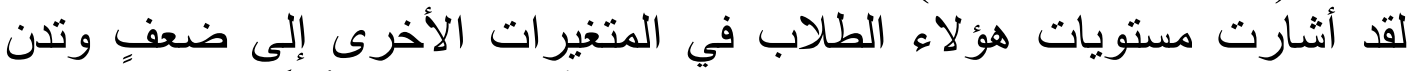

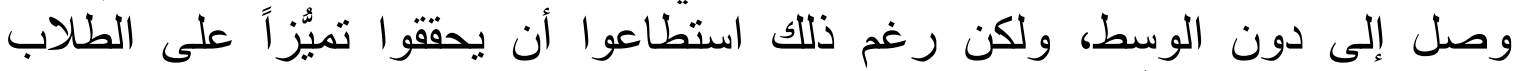

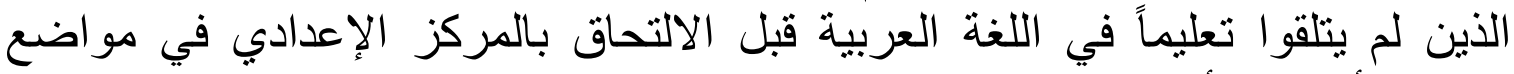

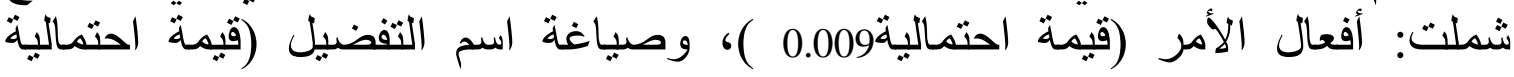

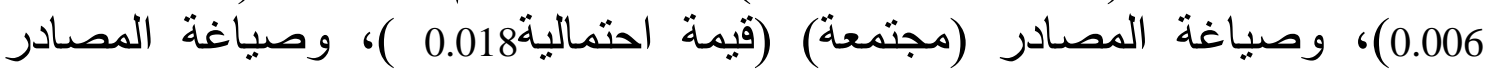


السماعية (قيمة احتمالية 0.023 ))، وصياغة المصادر القياسية (قيمة احتمالية0160.016 ) ومواضع العلة (قيمة احتمالية الإنة

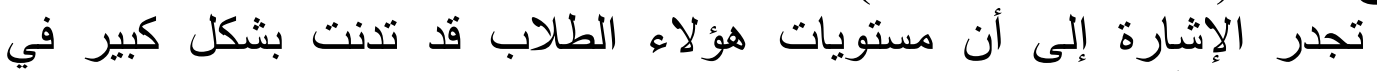

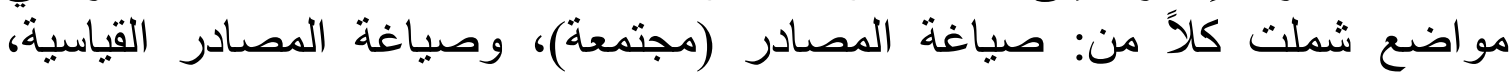
وصياغة اسم التفضيل، و الجموع.

\section{نوُُعُ (جنس) الطلاب Gender}

تمكن الطلاب الذكور من تحقيق مستويات عالية في كلّ من مطابقة حروف الطن

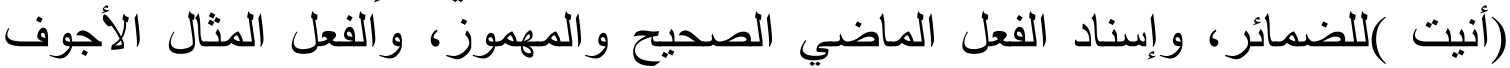

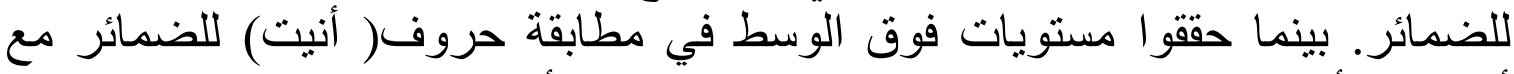

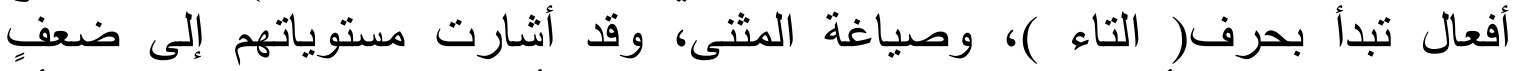

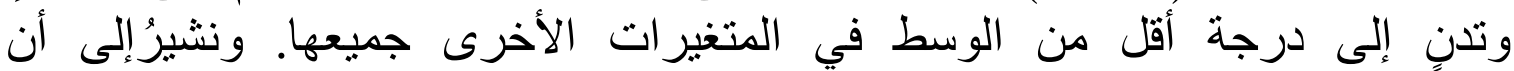
مستويات هؤلاء الطلاب الذكور كانت أقل من مستويات الطالبات الإناث في كل

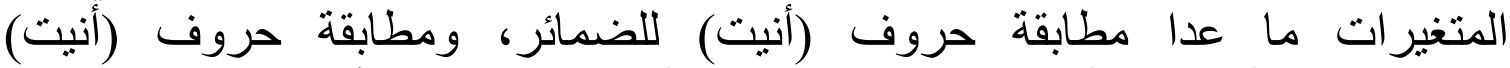

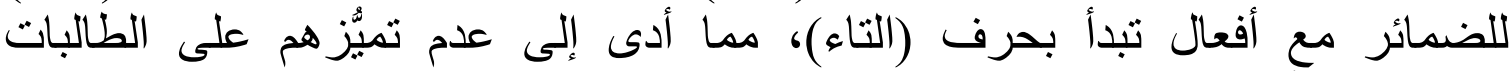

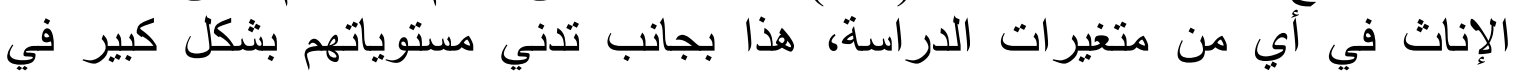

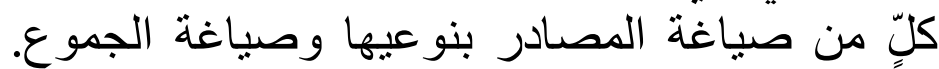
استطاعت الإناث (الطالبات) تحقيق مستويات عالية في كلٍ من من مطابقة

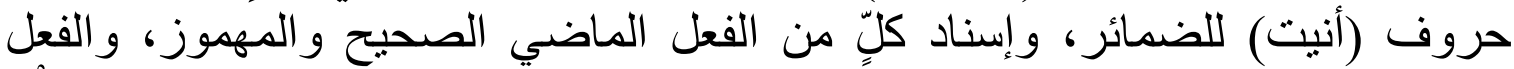

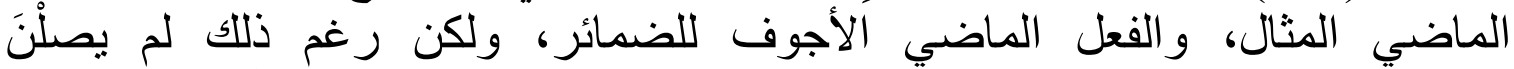

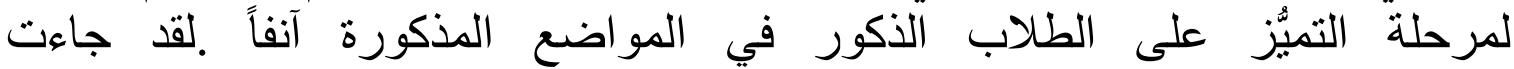

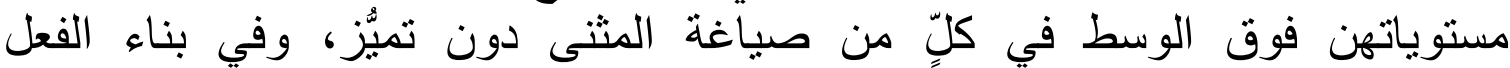
الماضي للمجهول الذي استطعن أن يتميَّزنَ فيه على الطيه الطلاب الذكور (قيمة احتمالية

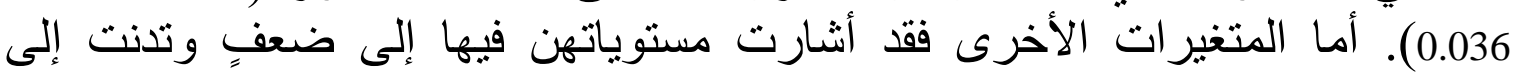

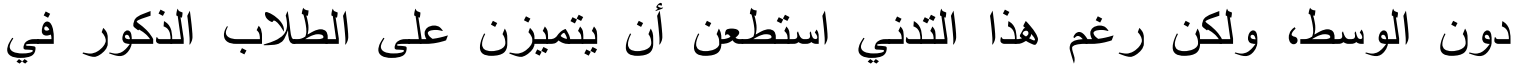

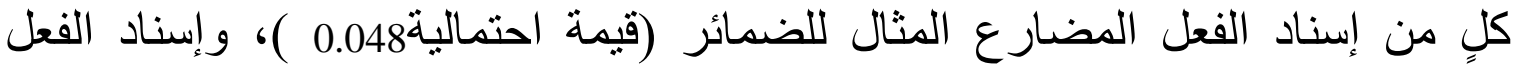

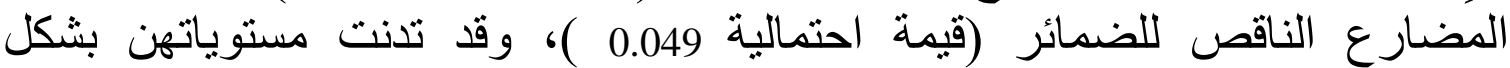
كبير في صياغة المصادر و الجموع.

\section{تخصُصنات الطلاب \\ الطلاب المتخصنصون الطلاب في اللغة الإنجليزية}

تَمَكَّنَ الطلاب المتخصنصون في اللغة الإنجليزية من تحقيق مستويات فوق الإنية الوسط

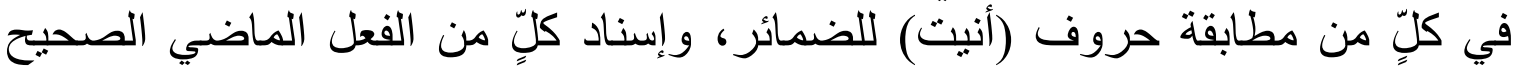

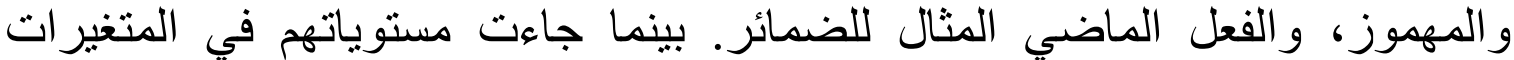
الأخرى جميعها دون الوسط وهي أقل المستويات بين التخصصيات الفيات المختلفة، فيما

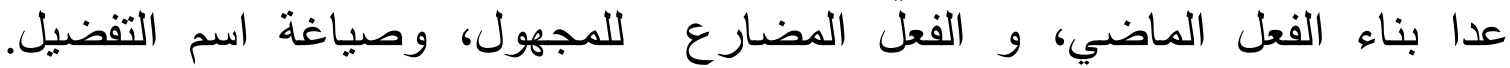




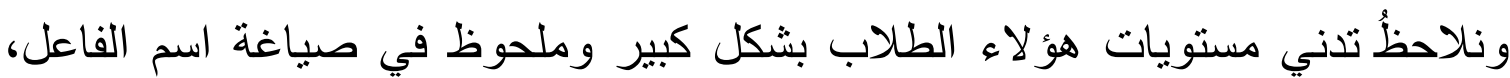

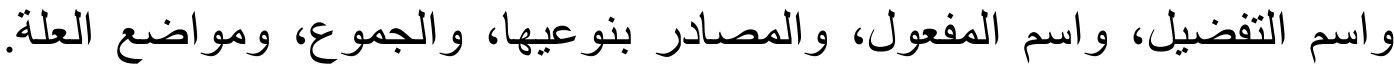

$$
\text { القُّلاب المتخصنصون في الثريعة الإسلامية }
$$

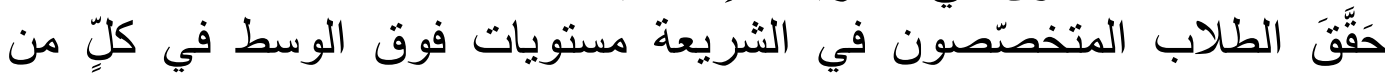

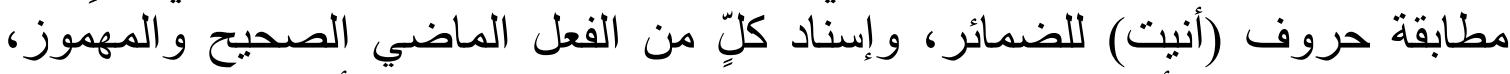

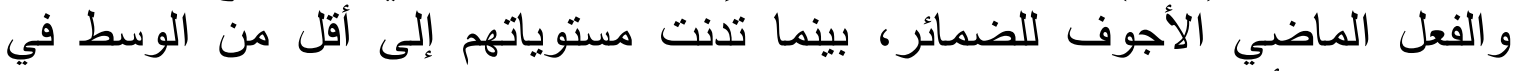

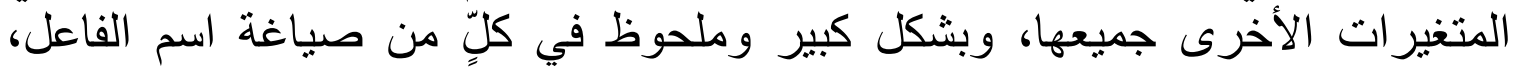

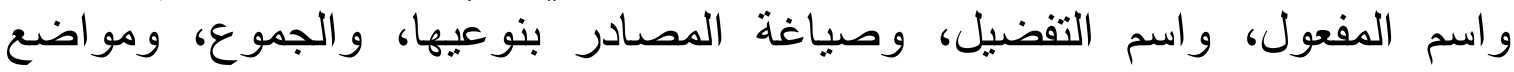
العلة.

\section{الطلاب المتخصّصون في العلوم الإنسانية}

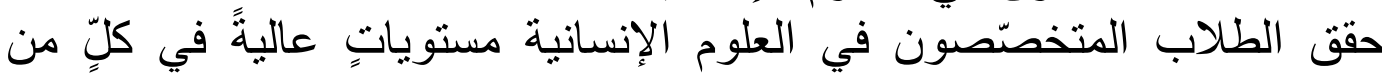

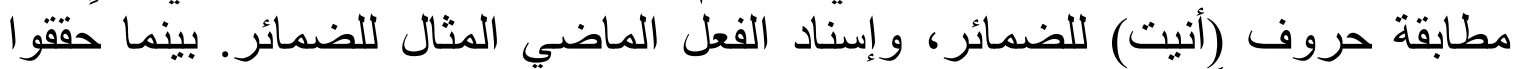

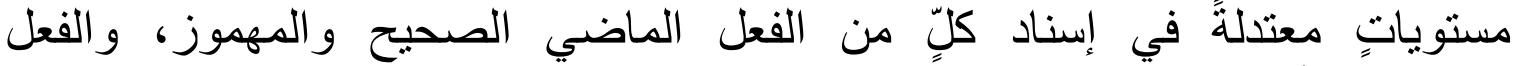

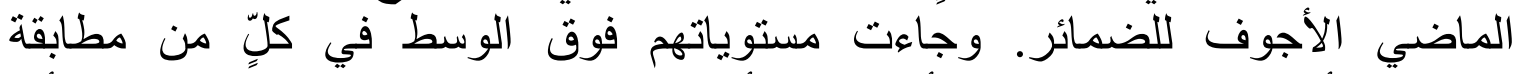

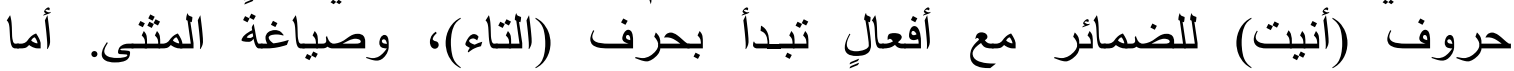

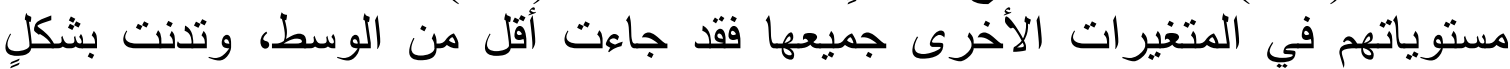

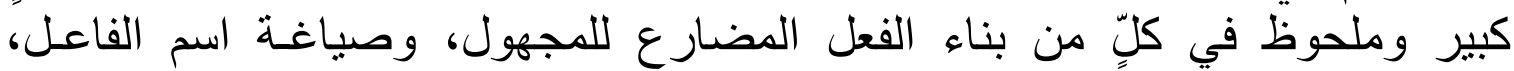

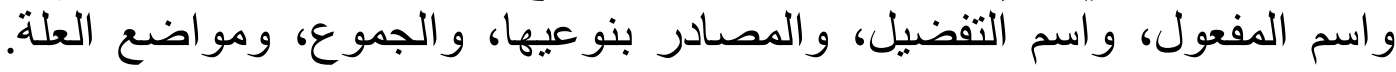

استطاع الطلاب المتخصّصون في معارف الفي الوحي تحقيق مستويات عالية في

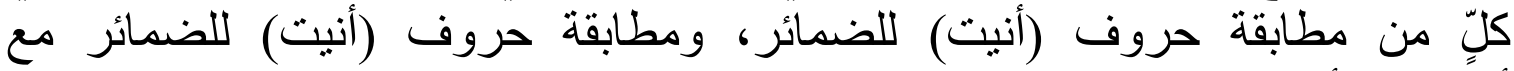

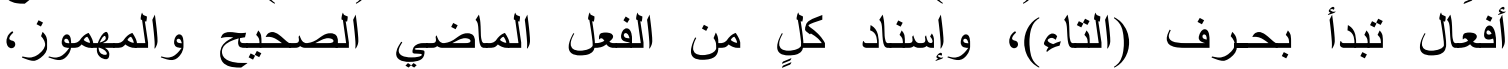

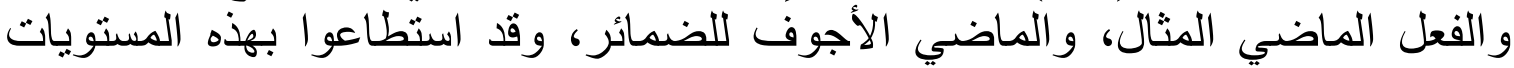

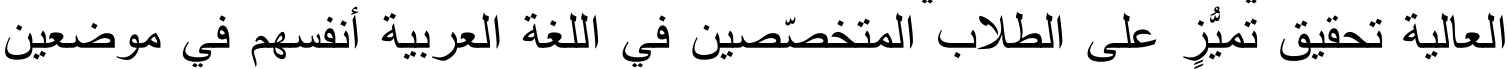

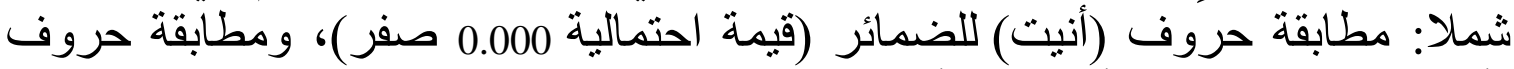

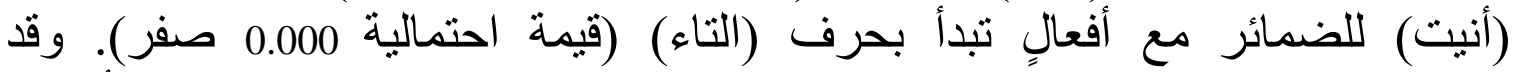

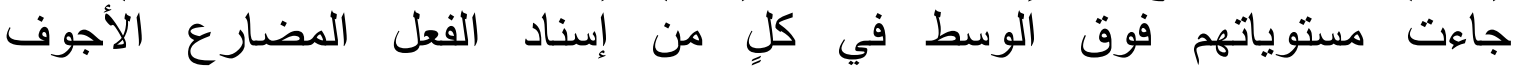

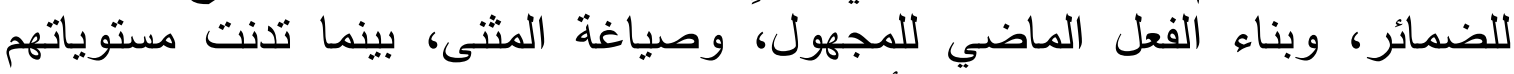

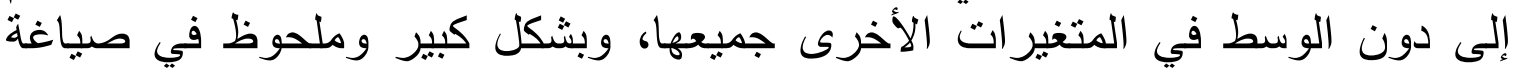

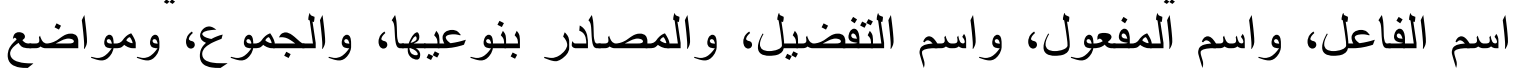




\section{الطلاب المتخصّصون في اللغة العربية} حقق الطلاب المتخصنصون في اللغة العربية مستويات عالية في كلٍ من الِّن

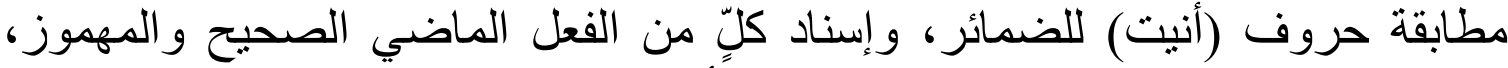

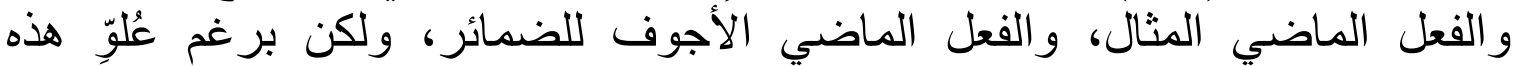

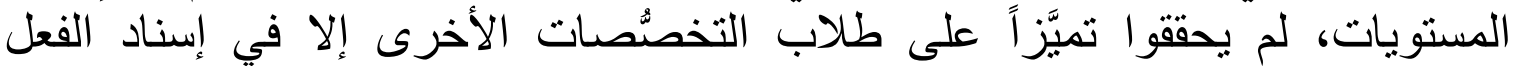

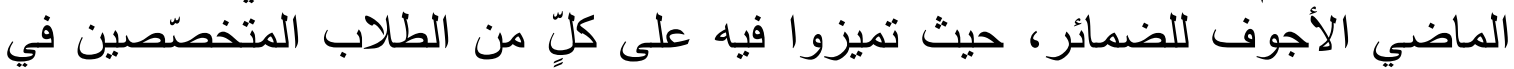

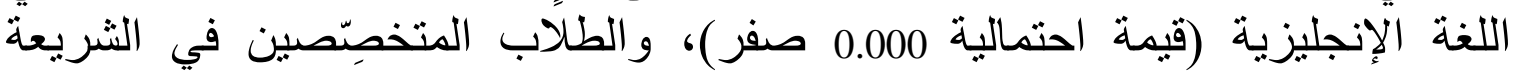

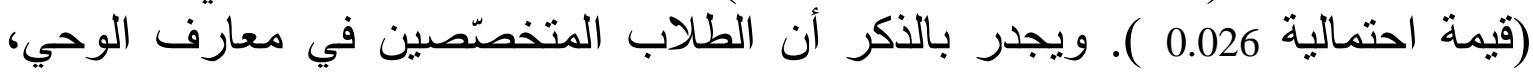

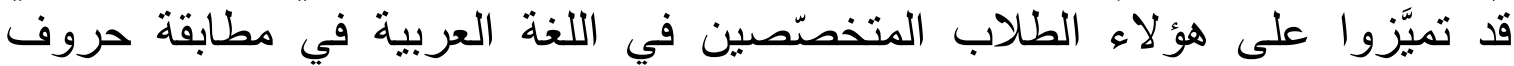

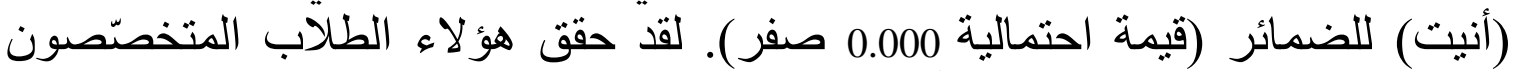

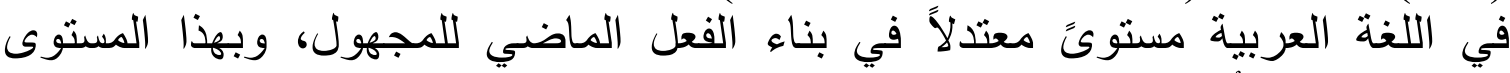

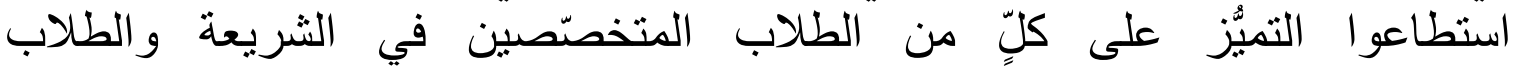

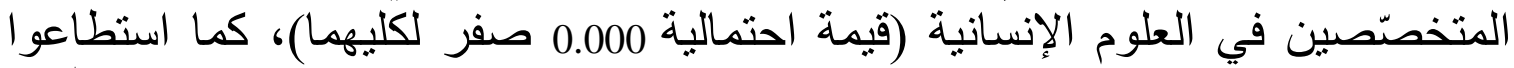

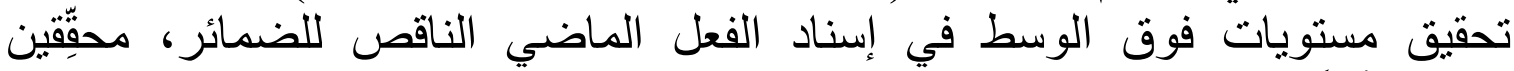

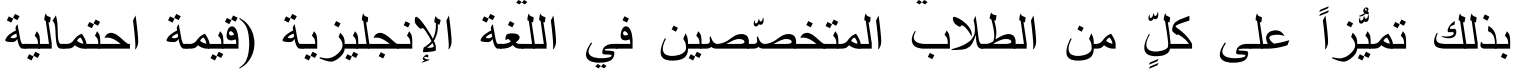

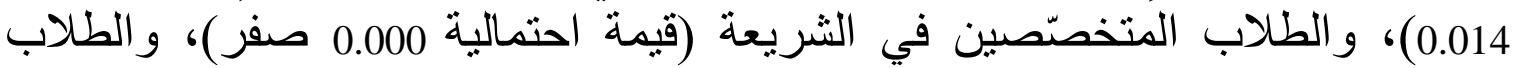
المتخصنصين في العلوم الإنسانية (قيمة احتمالية 0.049 الطئ ).

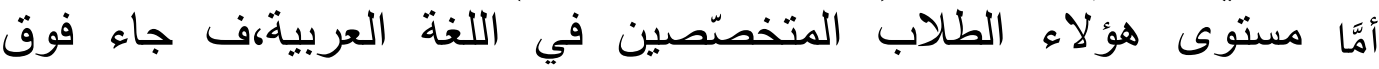

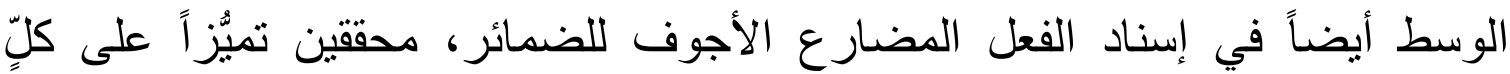

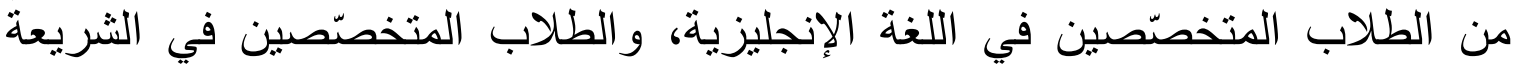

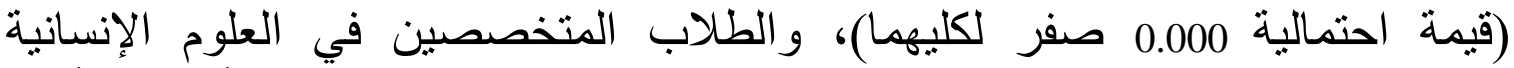

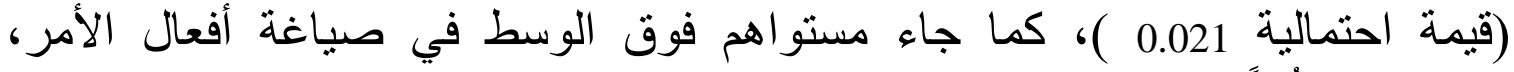

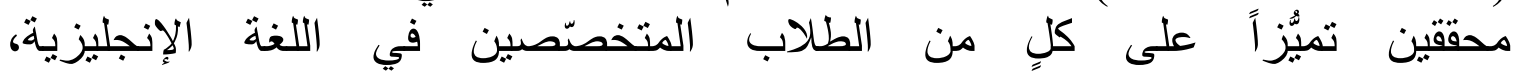

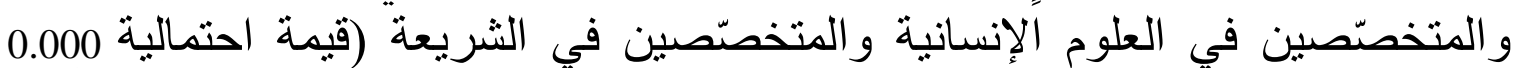

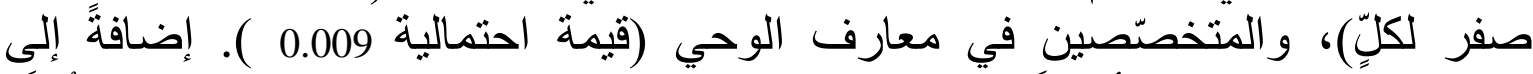

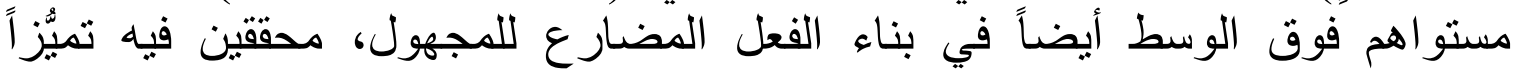

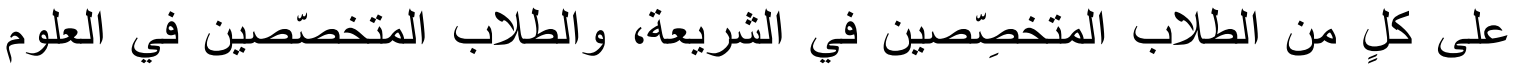

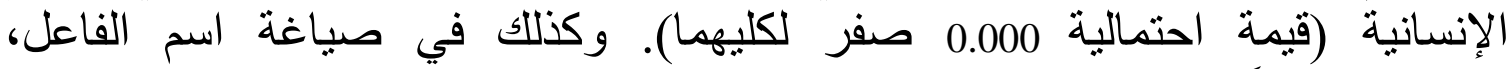

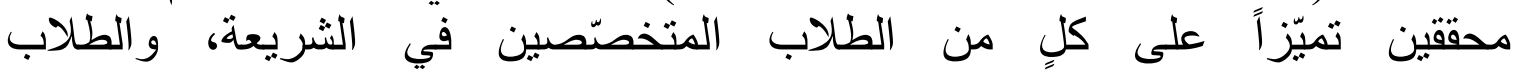
المتخصِّصين في العلوم الإنسانية (قيمة احتمالية 0.003 لكليهما).

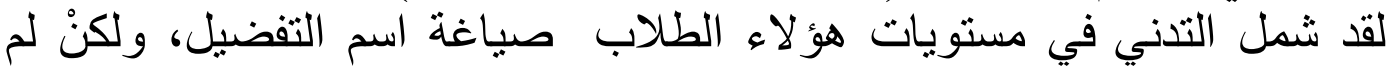

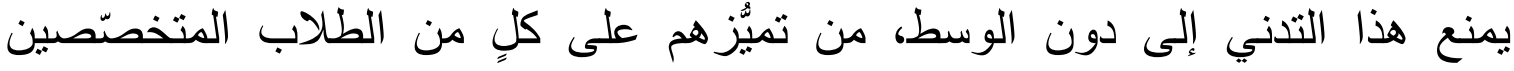
في الثريعة (قيمة احتمالية0.020 )، والطلاب المتخصيّصين في العلوم الإنسانية (قيمة

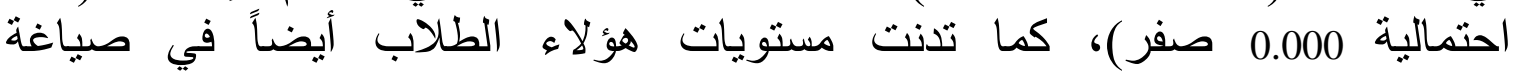

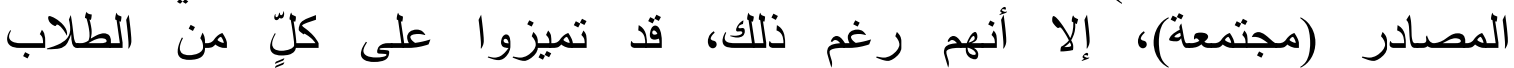

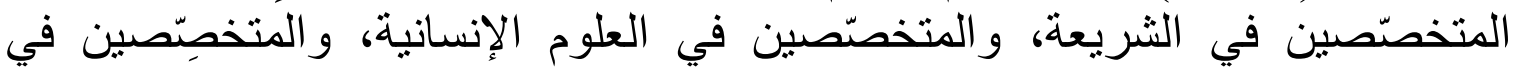


معارف الوحي (قيمة احتمالية 0.000 صفر لكلِّ)، والمتخصصين في اللغة الإنجليزية

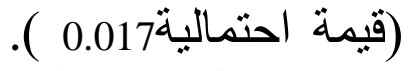

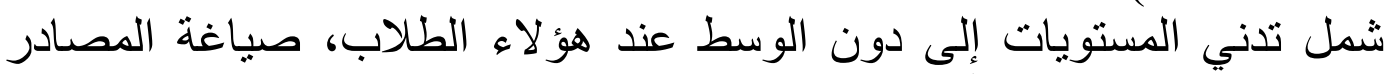

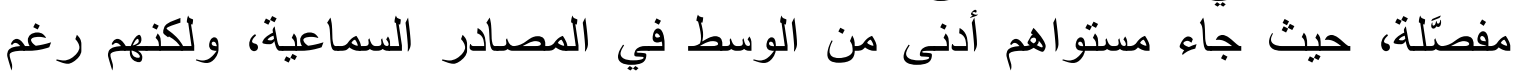

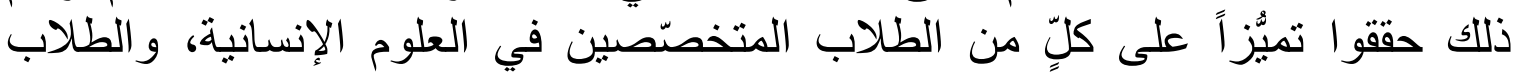

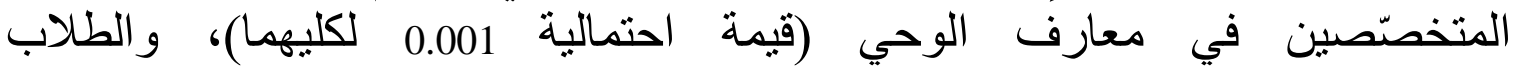

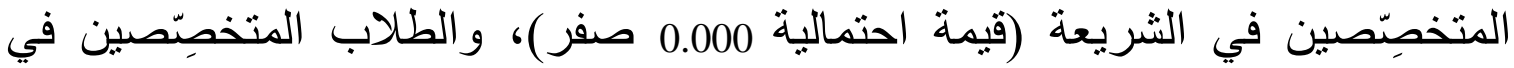

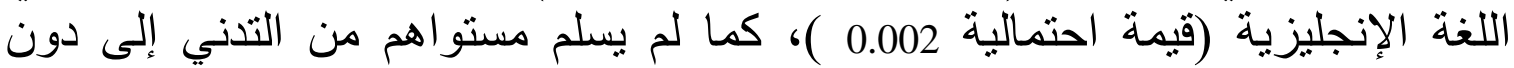

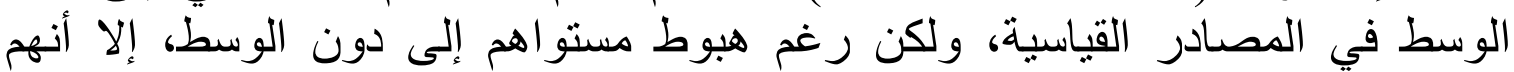

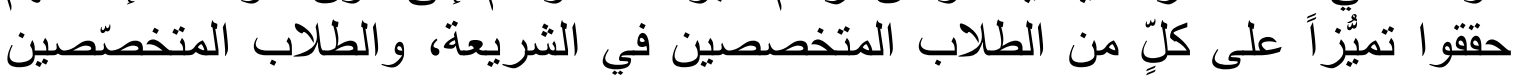

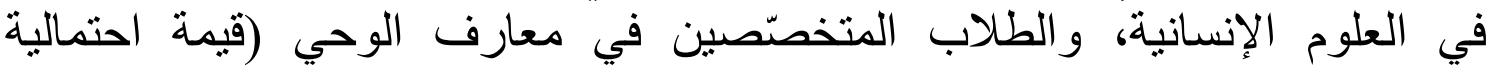

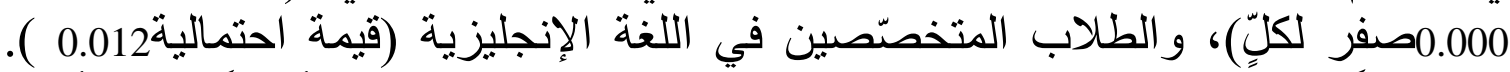

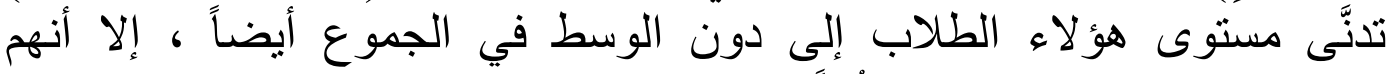

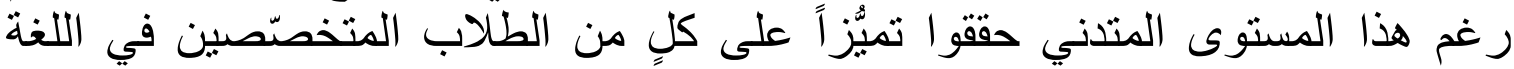

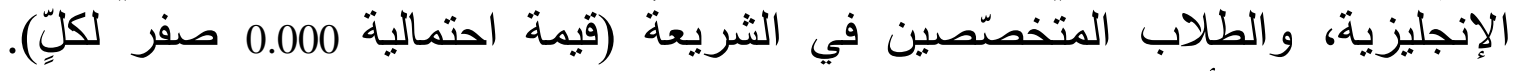

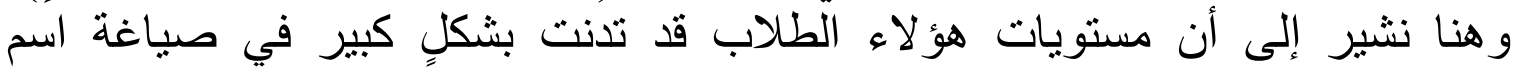
التفضيل، والمصادر القياسية والجموع.

\section{مقترحاتُ لتطوير مناهج اللفة العربية وتدريس قواعدها}

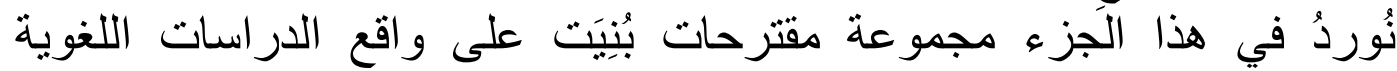

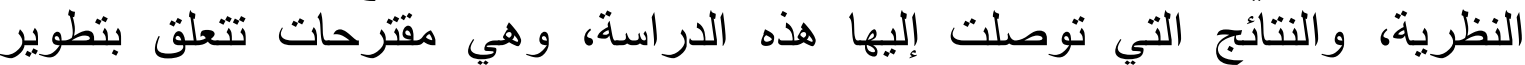

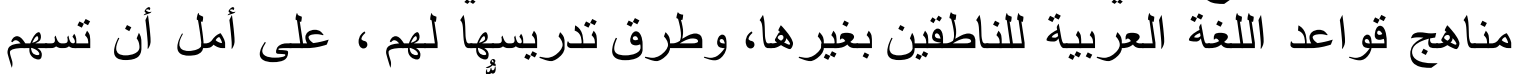

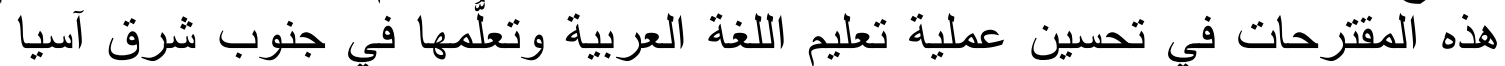

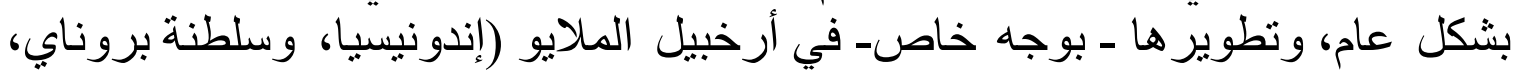
وسنغافورة، وجنوب ونطوبر مملكة تايلاند وماليزيا).

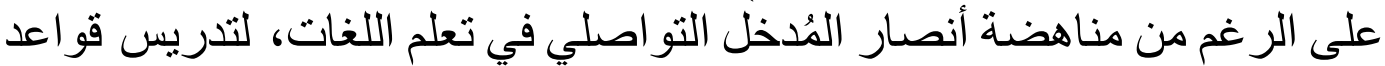

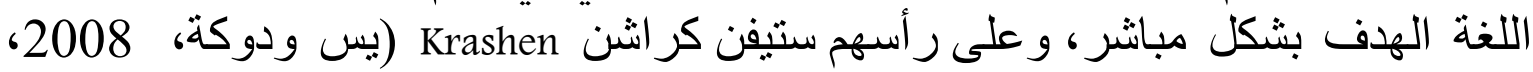

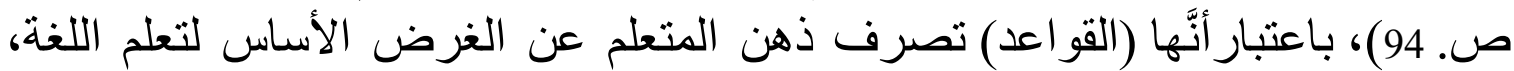

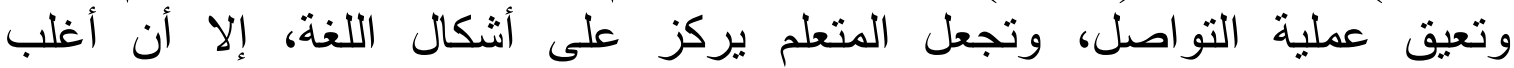

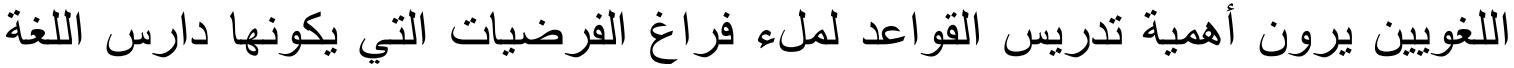

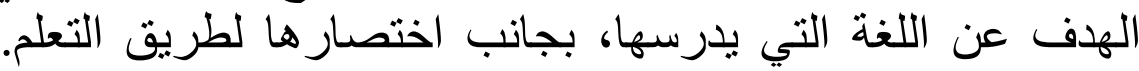

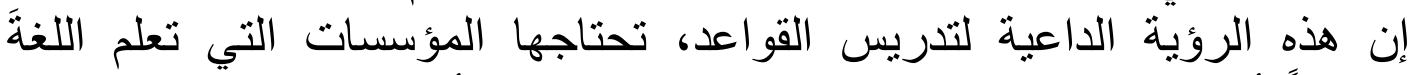

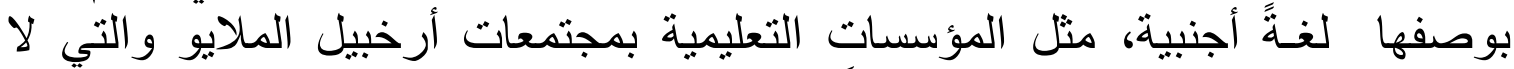

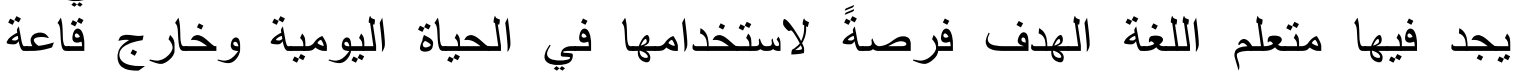

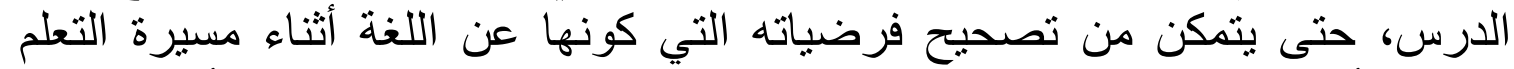

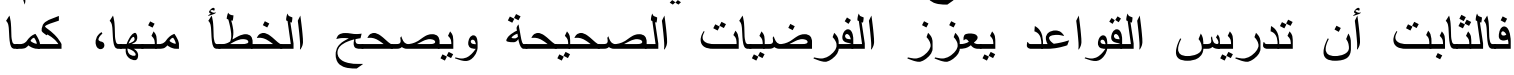

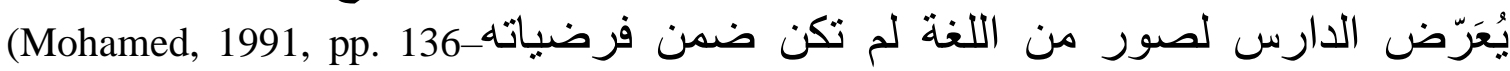




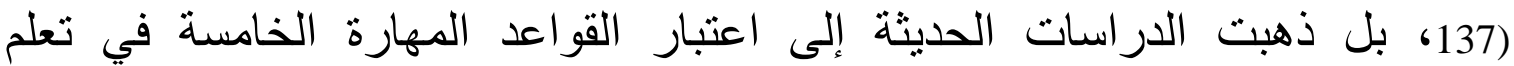

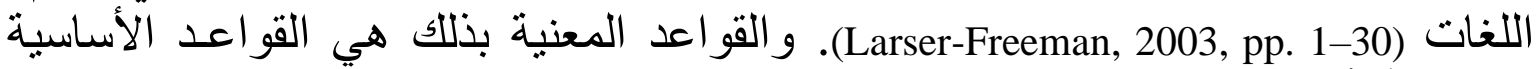

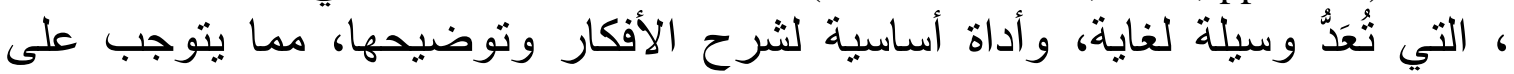

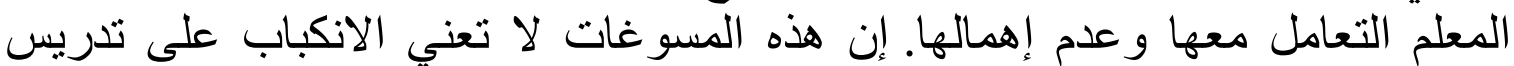

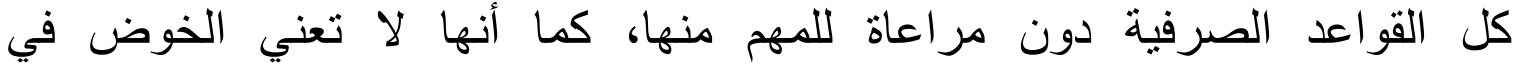

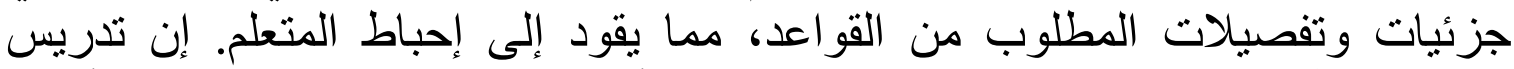

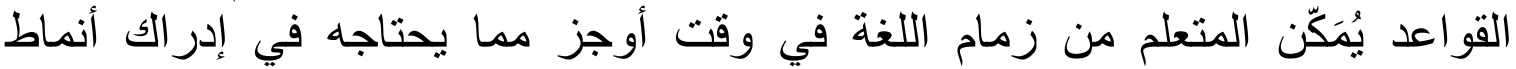

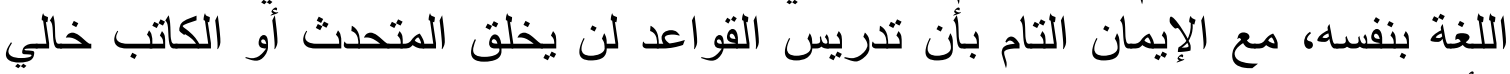

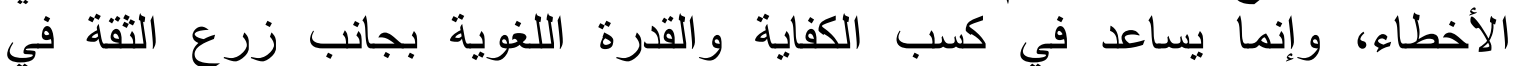

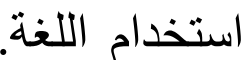

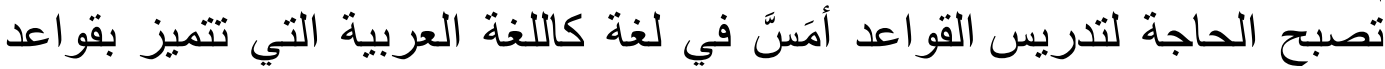

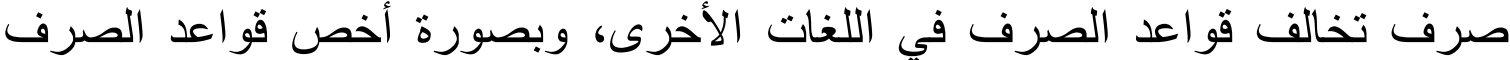

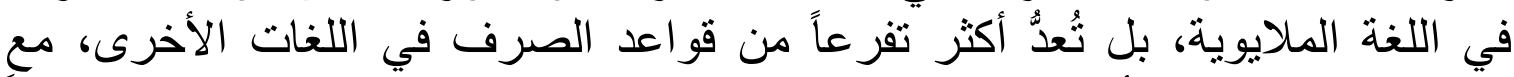

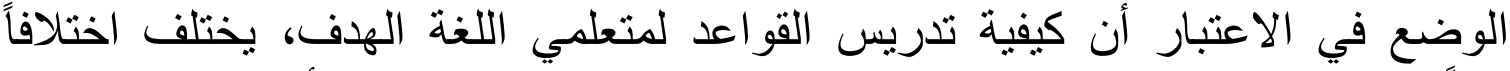

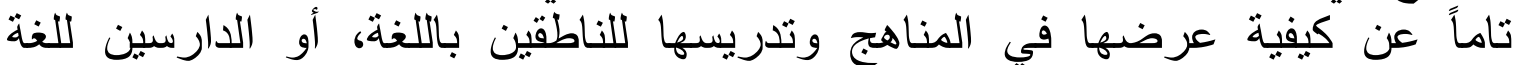

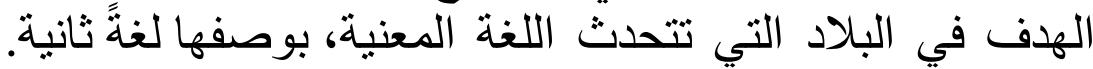

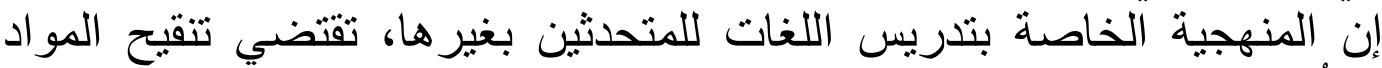

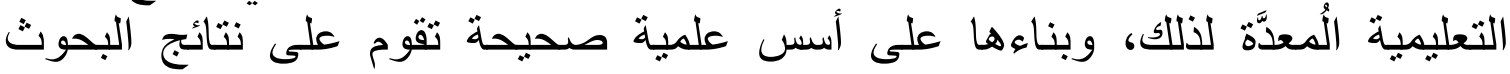

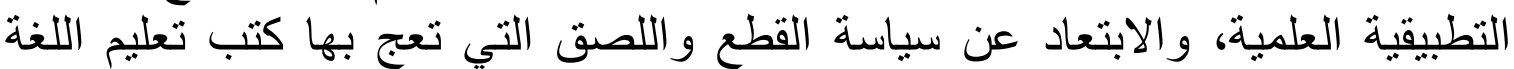

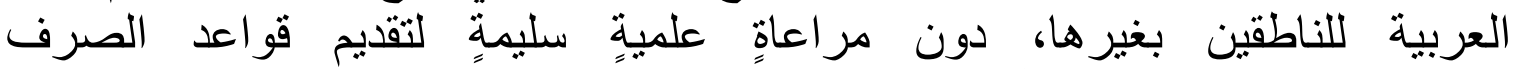

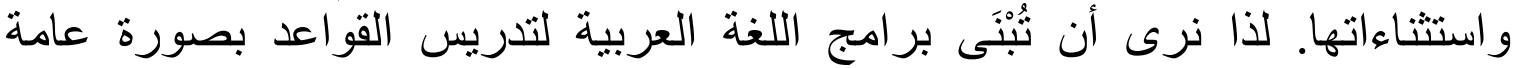
وقواعد الصرف بوجه أخص على المبادئ السبعة التالية:

\section{المدخل التواصلي Communicative Approach)}

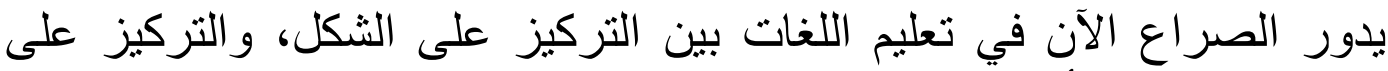

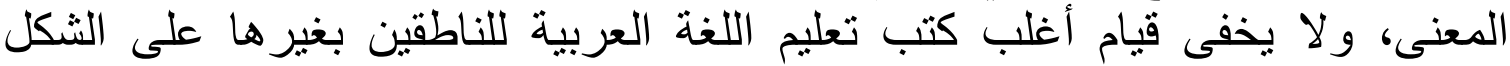

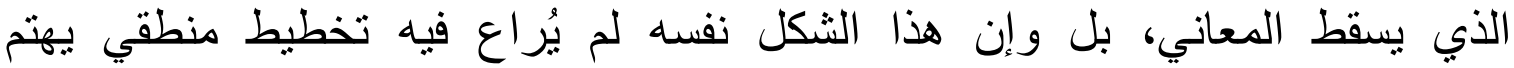

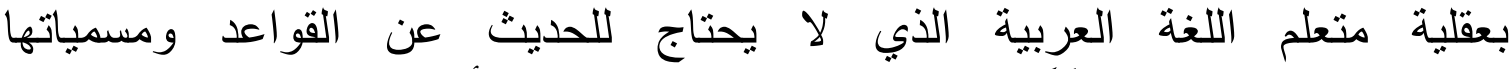

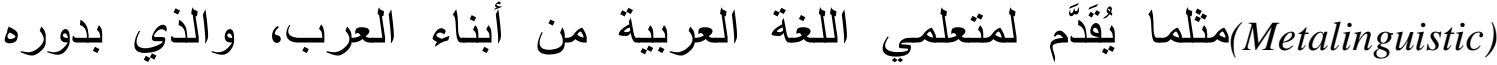
يؤدي إلى إلمام متعلم اللغة العربية بمسميات القاعدة دون الإلمام بكيفية تطبيقها لإنها

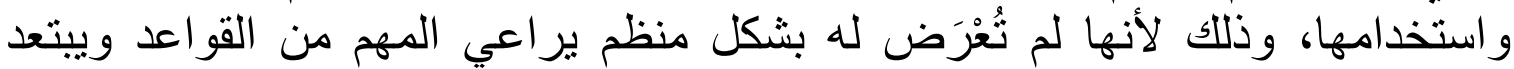

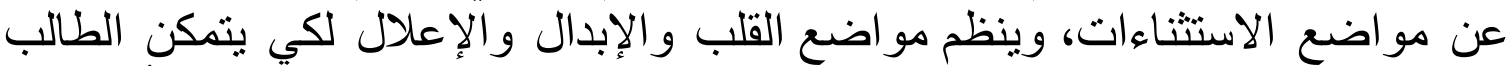

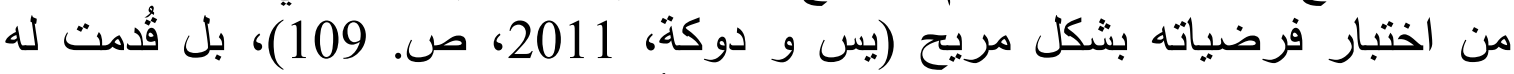

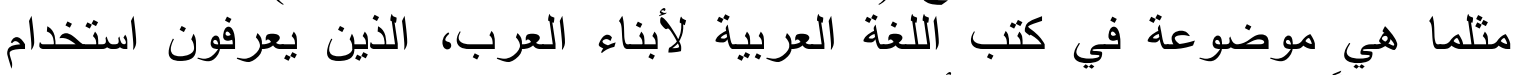
اللغة سلفاً بحكم الاكتساب، وأن كل ما يبتغونه في المدرسة هو الإلمام بفلسفة لإنة 


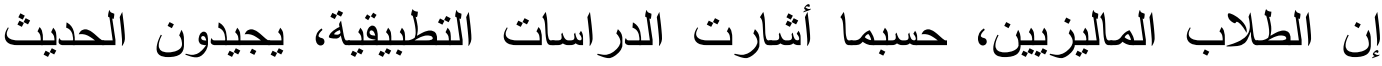

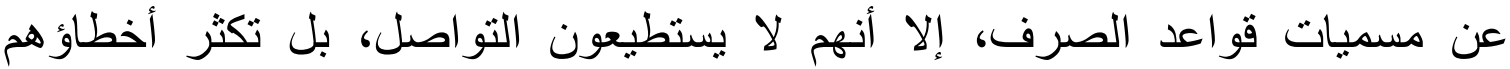

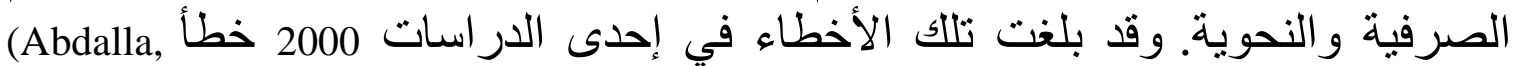

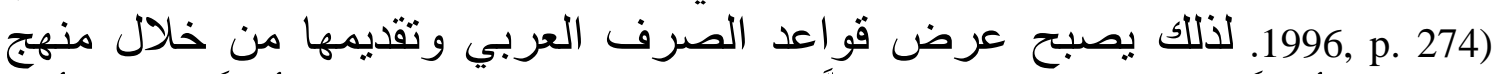

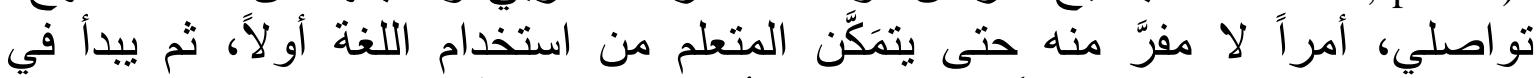

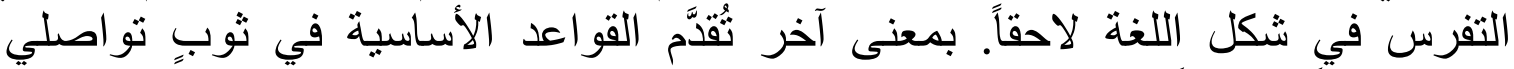

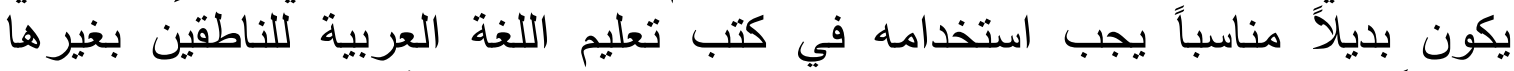

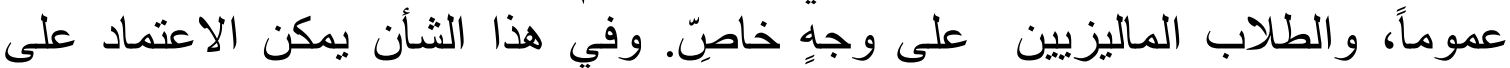

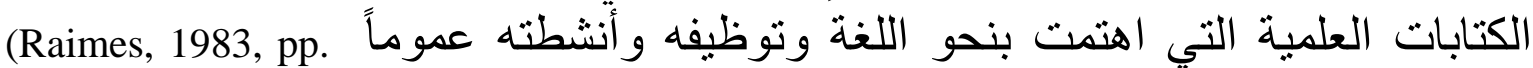

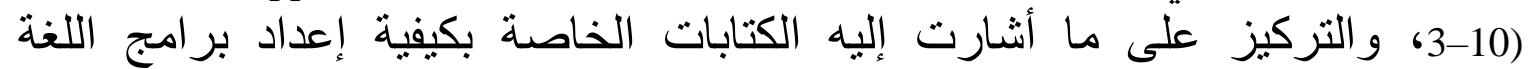

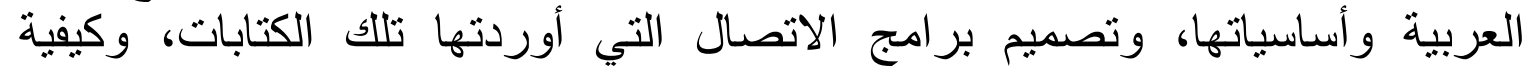
تعليم نحو اللغة العربية بوجه أخص (540-538) (Adam, 1998, pp.

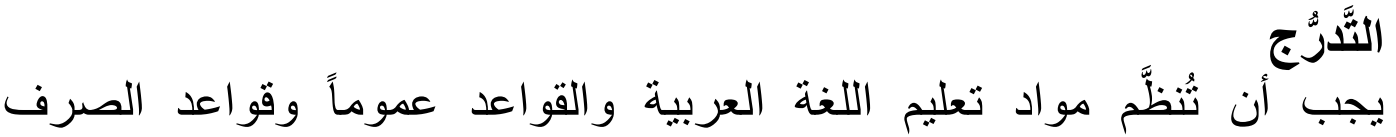

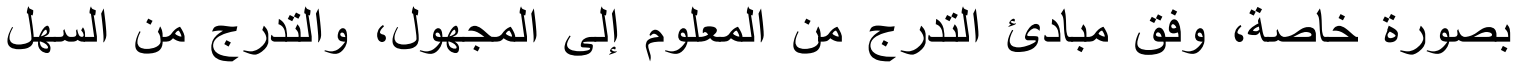

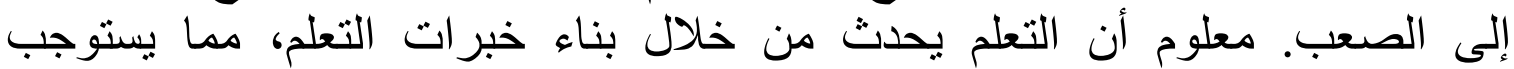

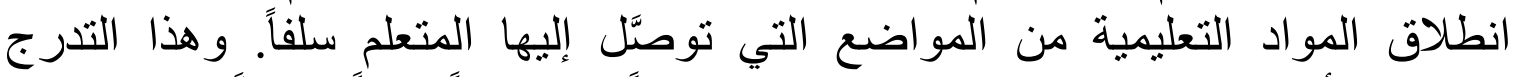

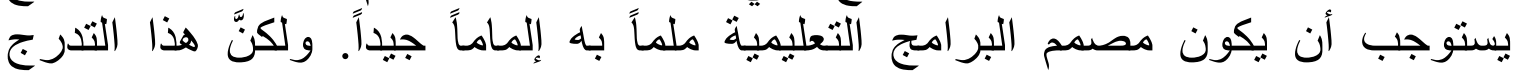

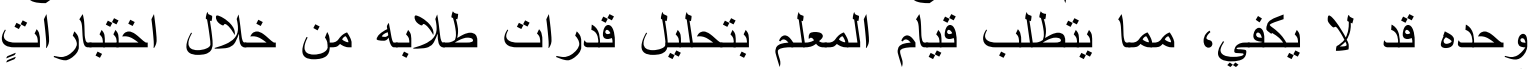

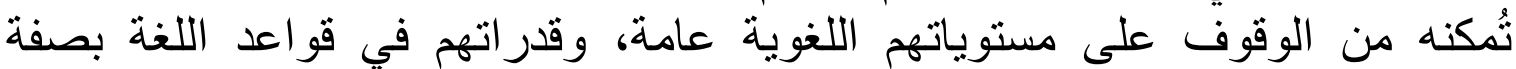

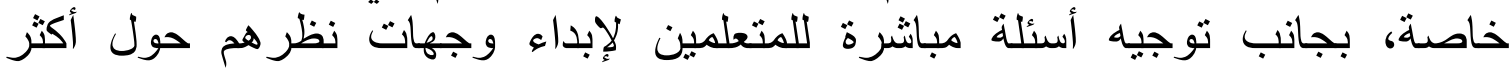

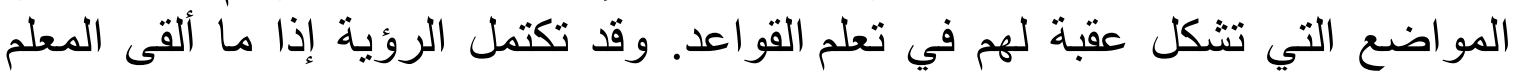

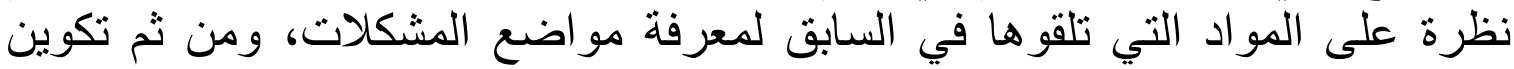

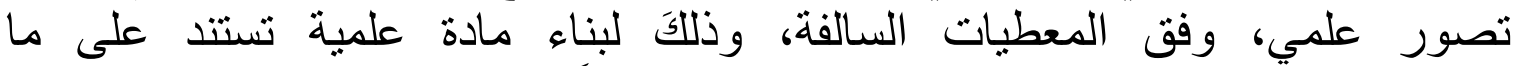

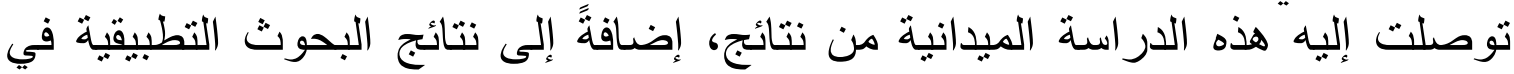

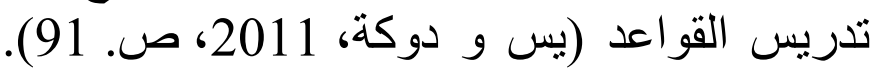
يقتضي مبدأ التدرج، الانطلاق من السهل إلى المعقد، فالقاعدة قد تبدو سهلة

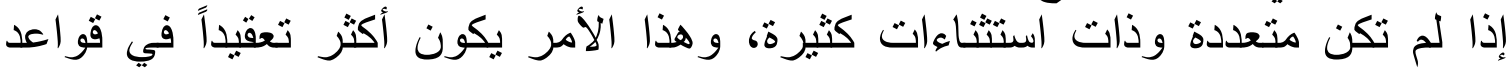

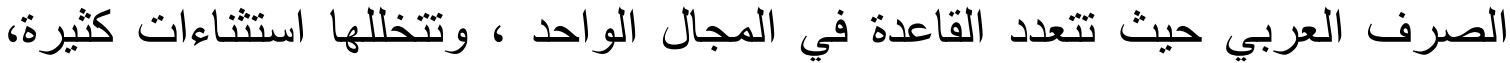

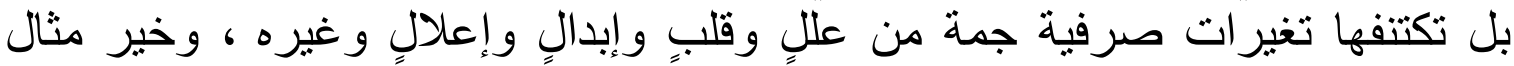

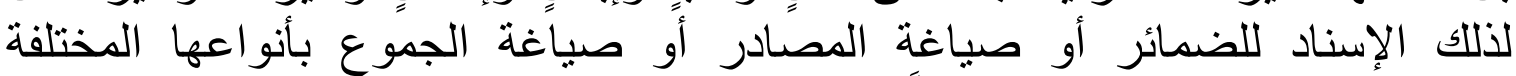

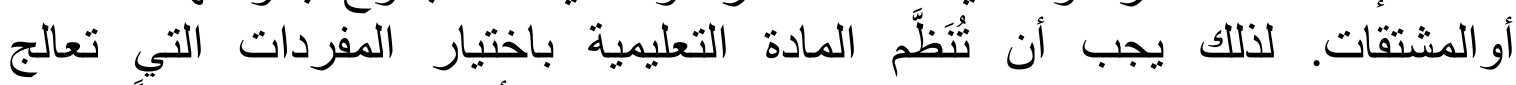

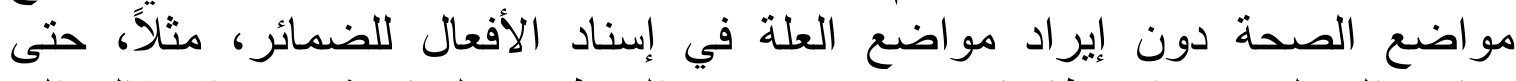

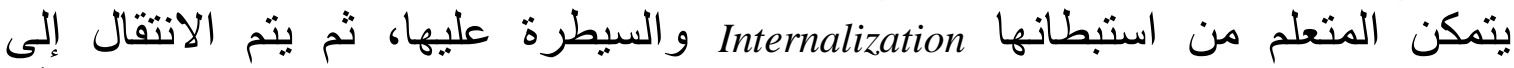

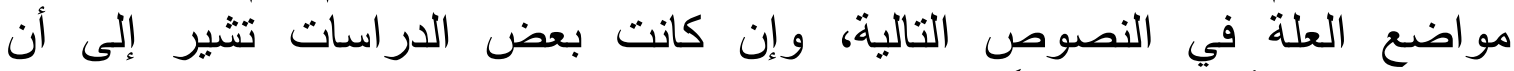

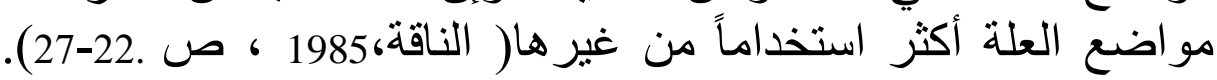


إن التدرج في عرض المادة والقاعدة، يحتاج إلى السيطرة الكاملة على المادة الفياة

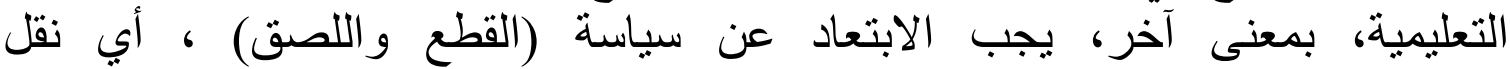

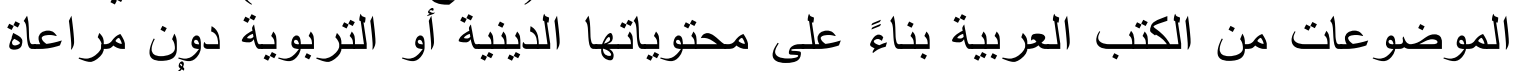

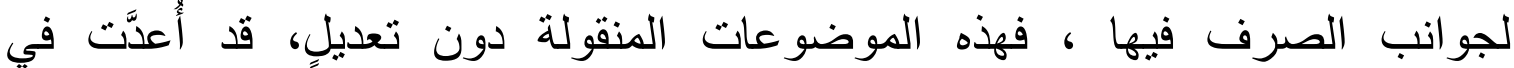

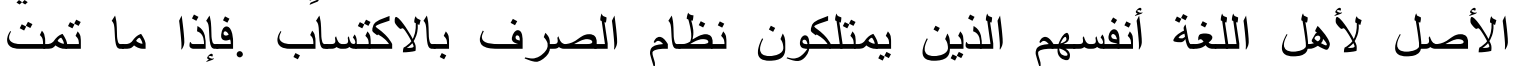

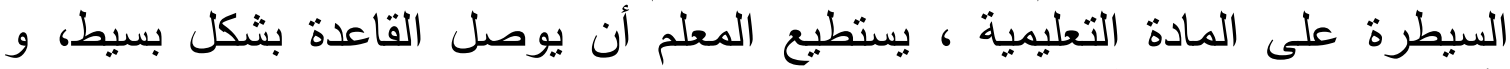

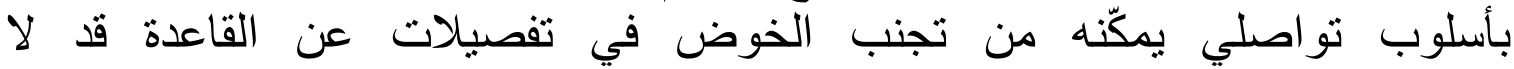
يستو عبها المتعلم، وهي قو اعد واستتناءات جلبتها المادة التعليمية غير المنظمة.

\section{اعتماد المواضع الصرفية الأكثر تكراراً}

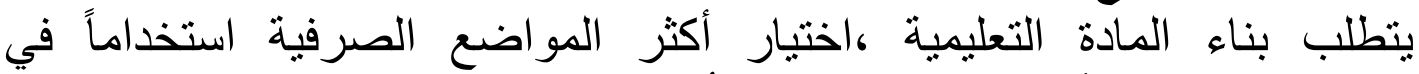

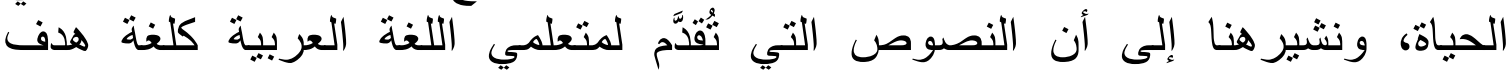

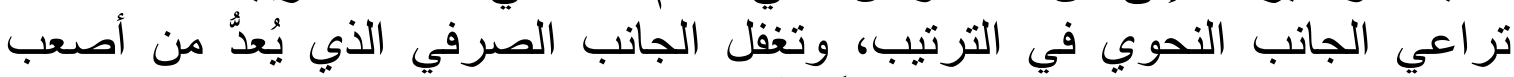

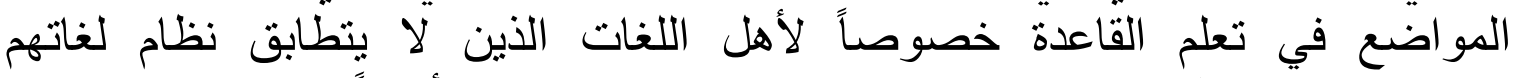

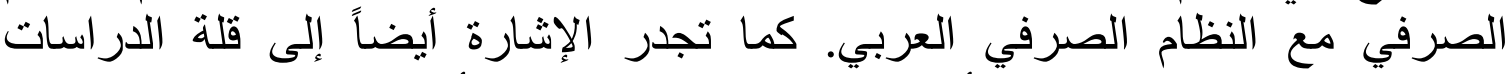

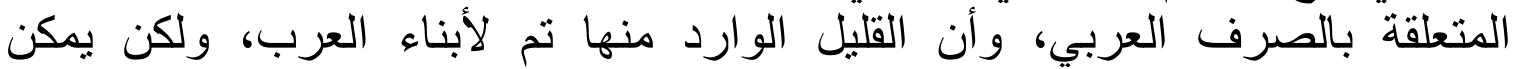

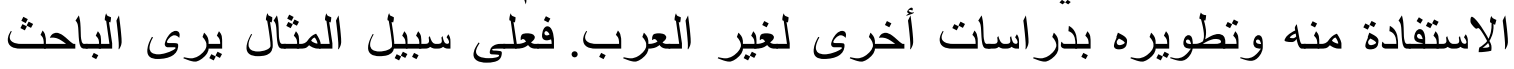

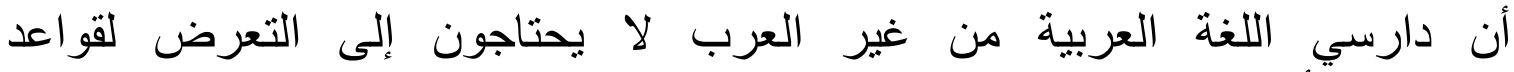

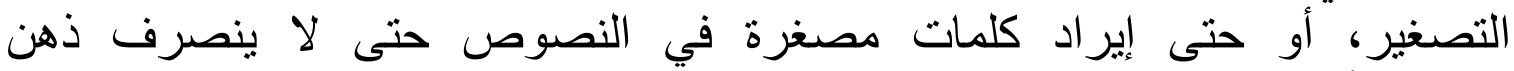
المتعلم لأشياء لا يحتاجها ويفرض الئ على المعلم شرحها.

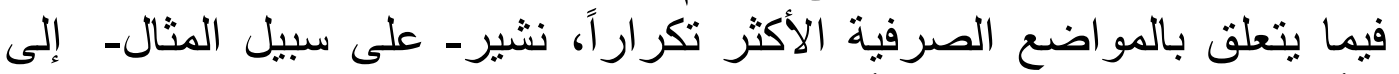

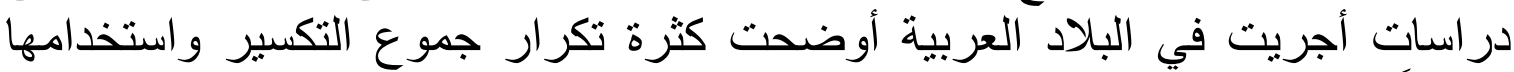

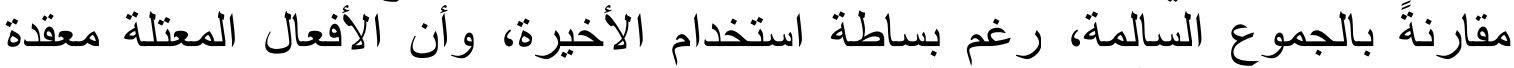

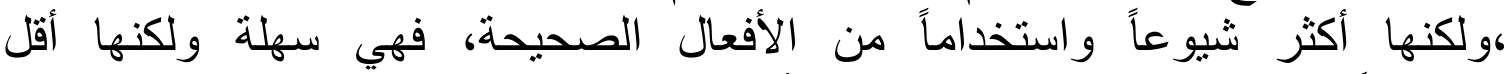

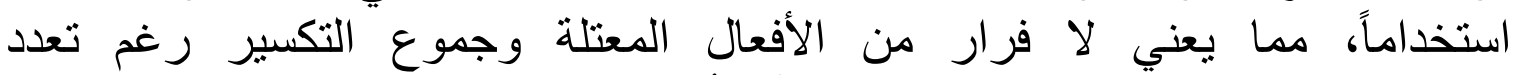

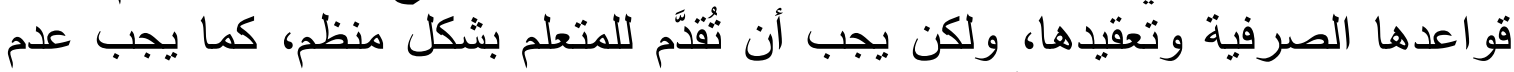

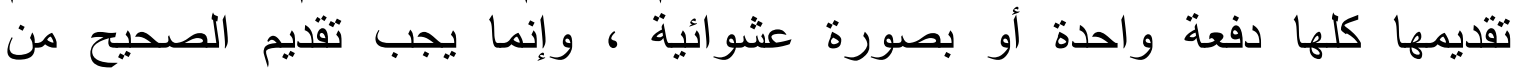

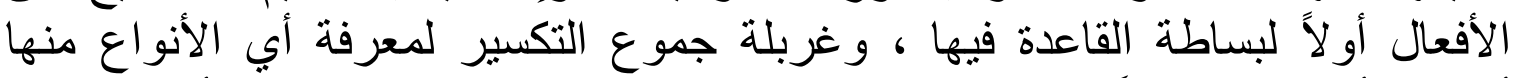

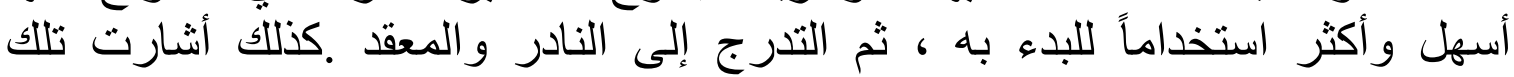

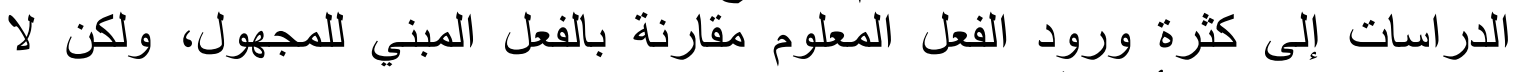

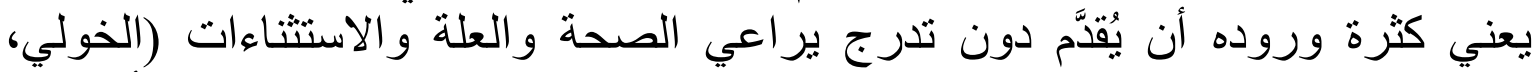

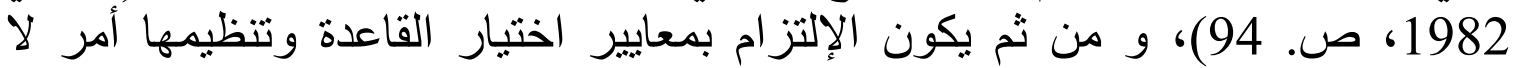

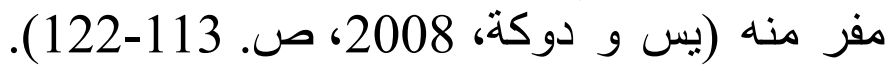

\section{تقليم القواعد من خلال المعاني}

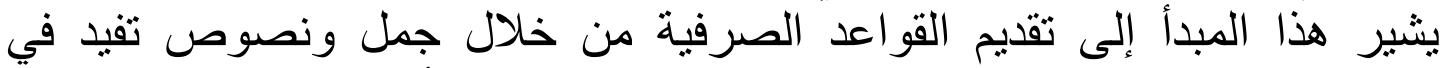

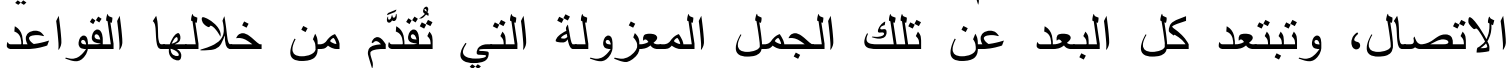




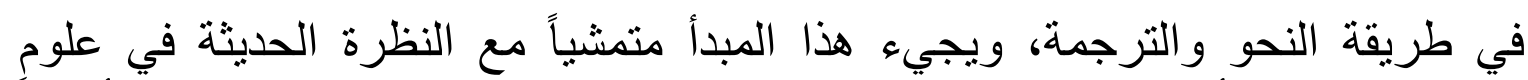

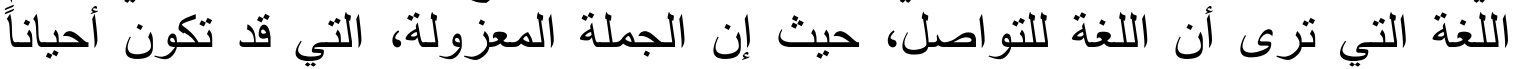

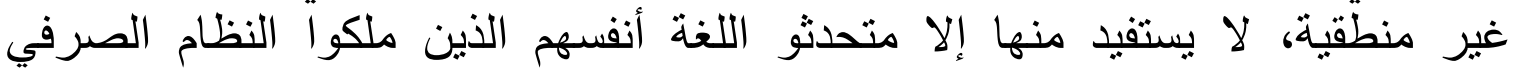

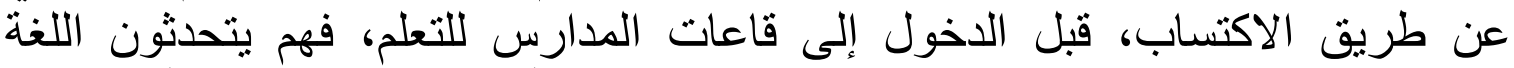

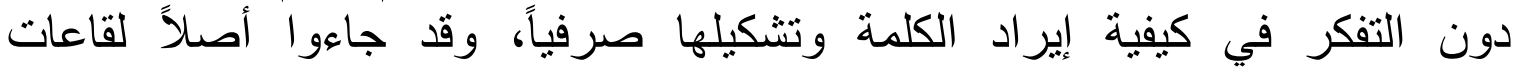

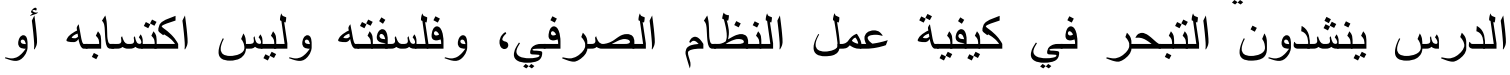
تعلمه.

\section{التوفيق بين الطرق التريسية}

يجب عرض القاعدة الصرفية بطريقة تجمع بين الصنية المزيا الإيجابية للطرق

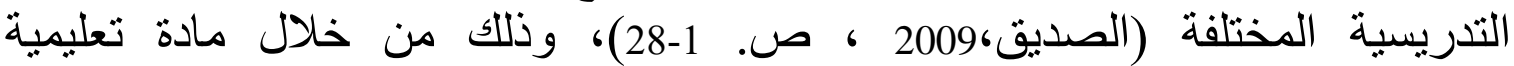

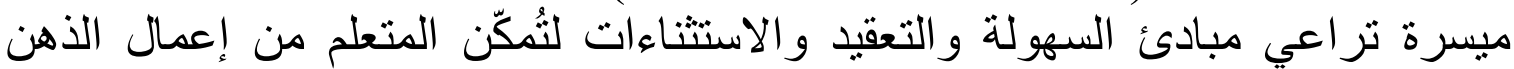

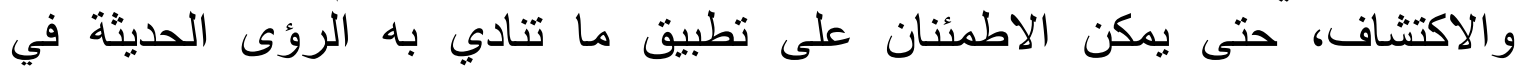

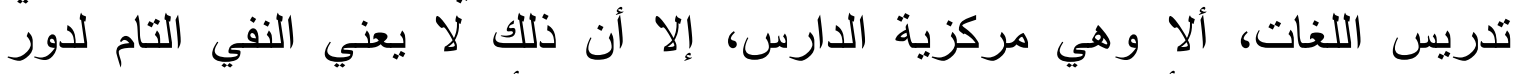

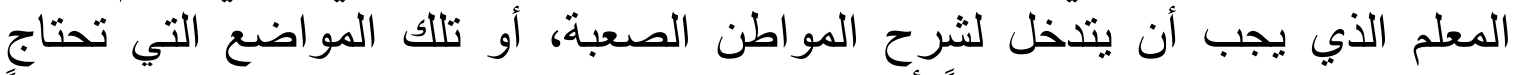

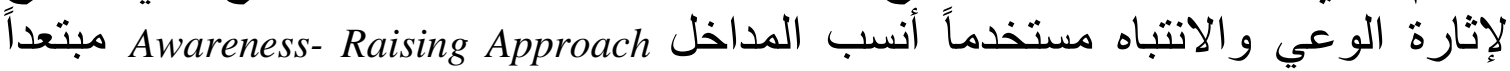

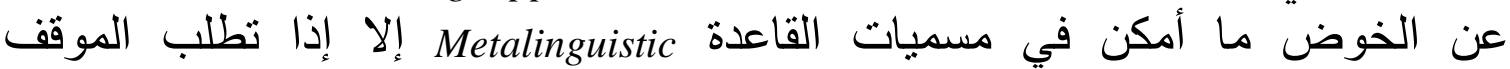
التدريسي التفيل في القاعدة وفق ظروف معينة (118-Corder, 1988, pp. 114).

\section{التخطيط الطولي والدائري للمادة الصرفية}

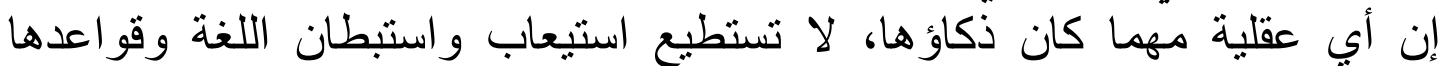

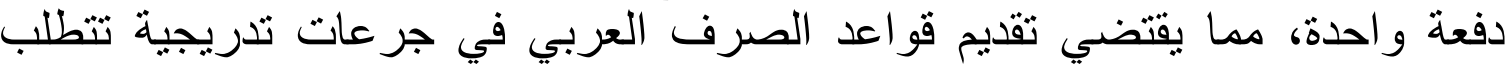

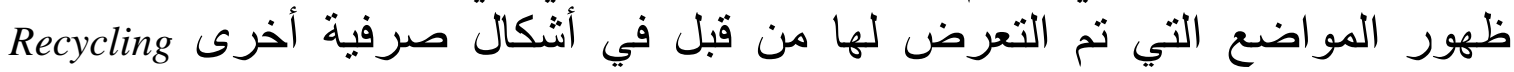
وفق الترتيب الصرفي الذي يتبناه المنهج (يس و دوكة، فئ 2008، صن.

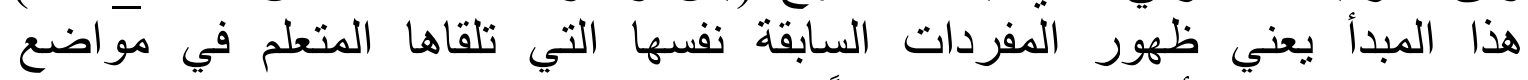

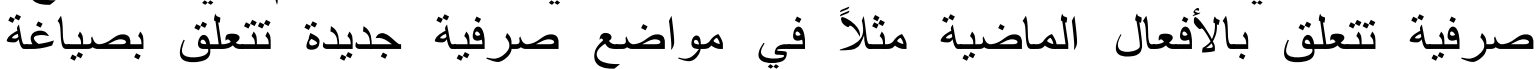

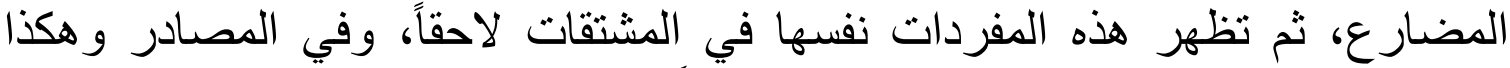

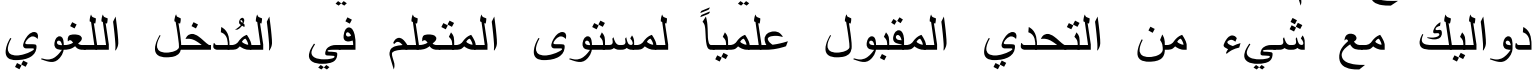

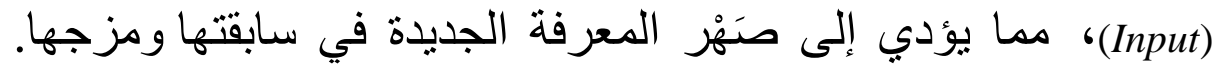

\section{بناء الجسور المعرفية}

يعدُّ المعلم حجر الزاعلة المعرفة في العملية التعليمية، وهو كما ذكرت شنيك (2016)

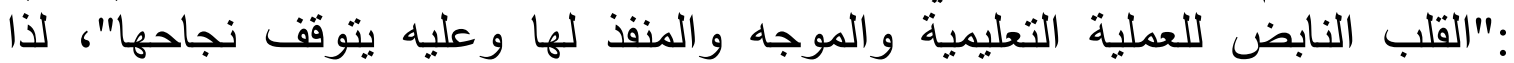

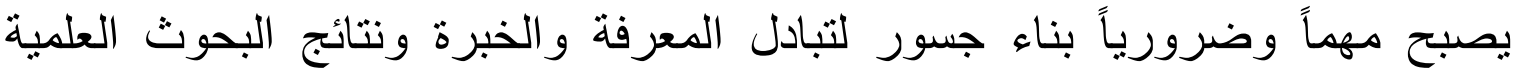

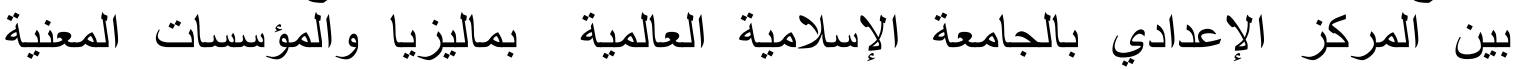

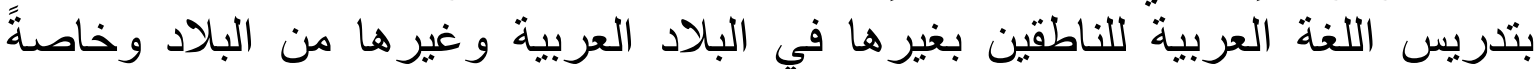

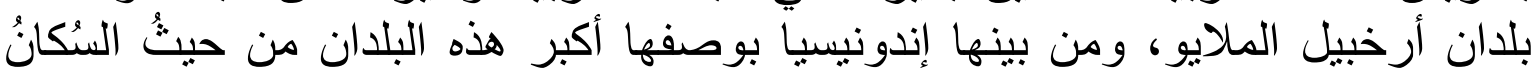


ومتعلمو العربية، بجانب إتاحة الفرصة للمعلمين الجدد في المركز الإعدادي

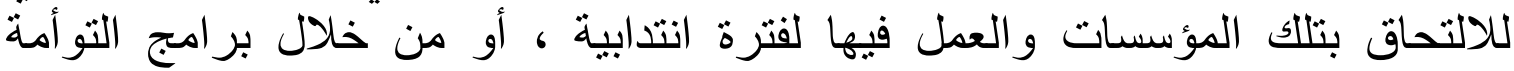

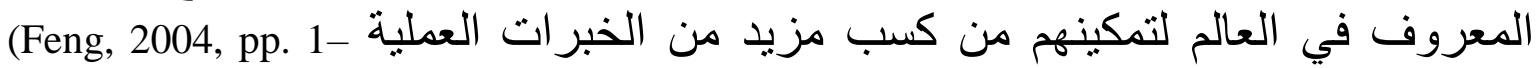

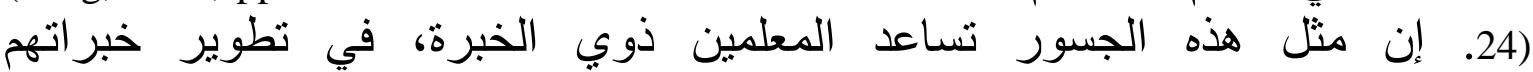

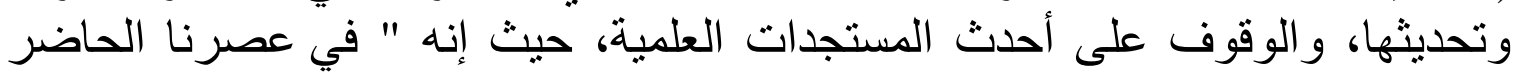

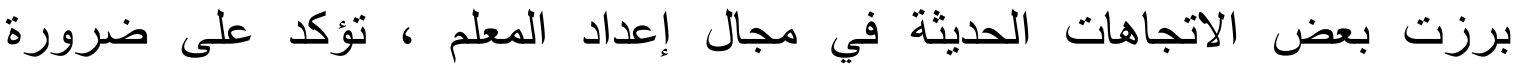

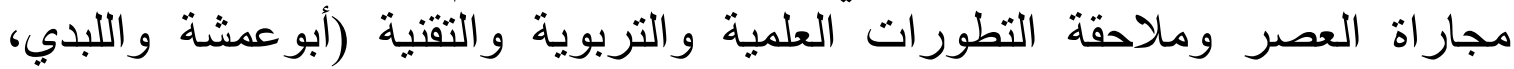

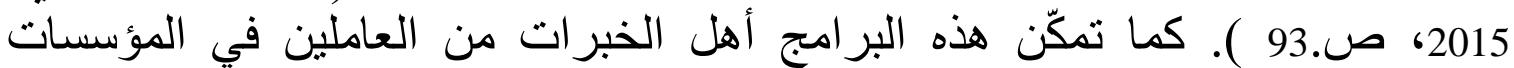

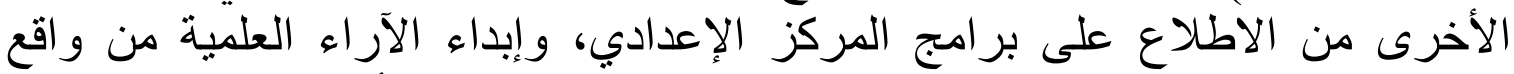

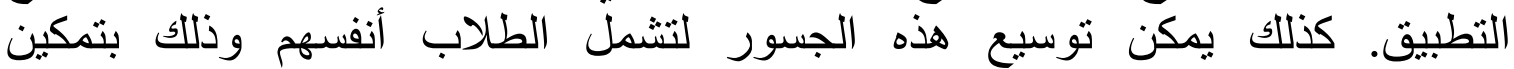

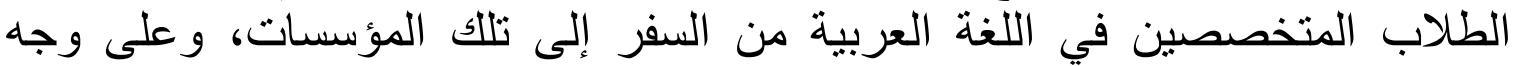
أخص البلاد العربية، لفترة زمنية كافية تمكنهم من الانغماس والانية الفنمار والمعايشة ولية (Immersion )

\section{الخلاصة}

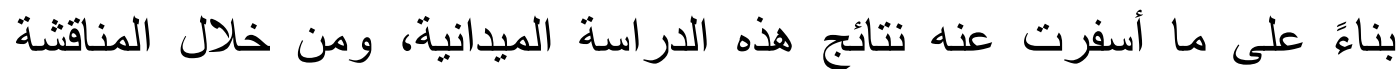

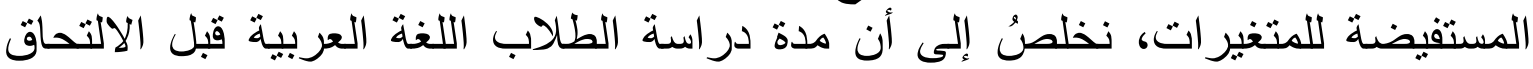

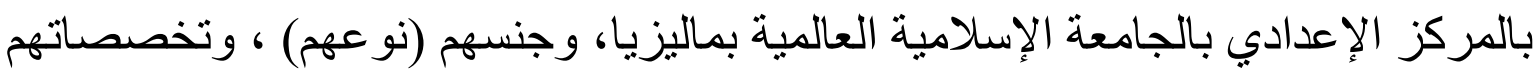

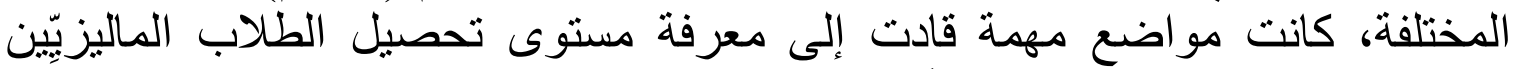

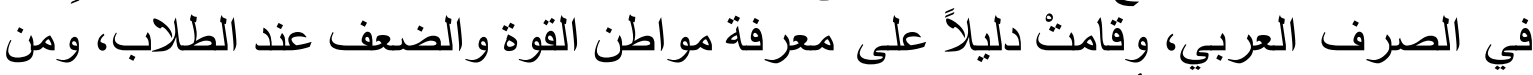

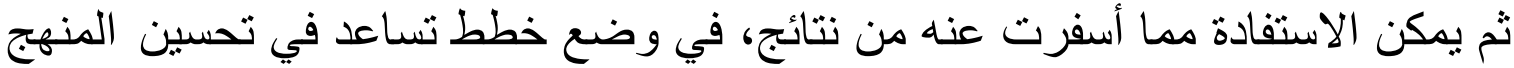

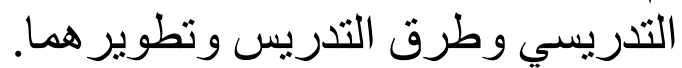
لقد أثنتت النتائج أن مستويات الطلاب الذين درسوا التيات اللغة العربية في المركز

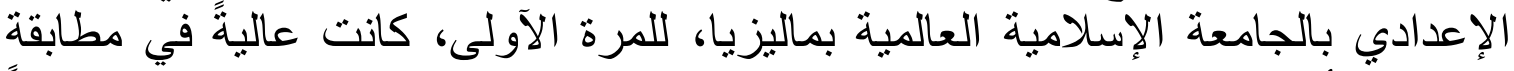

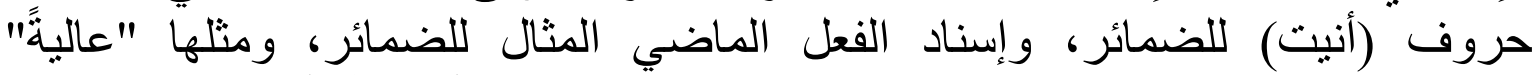

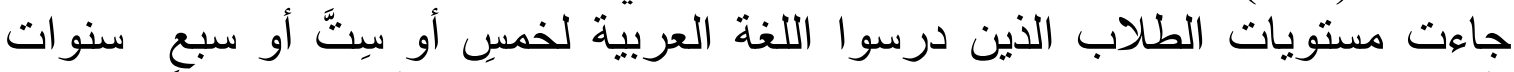

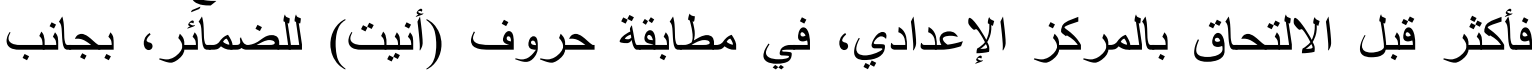

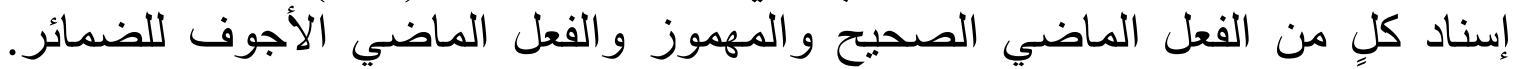

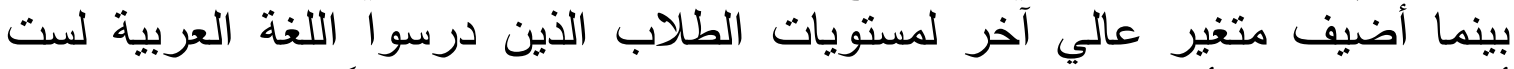

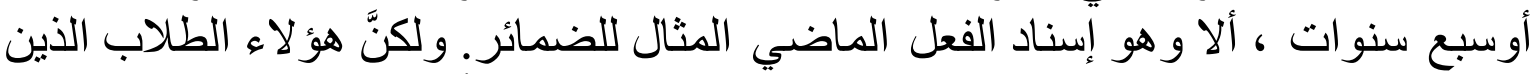

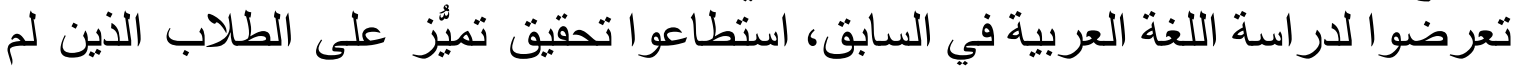

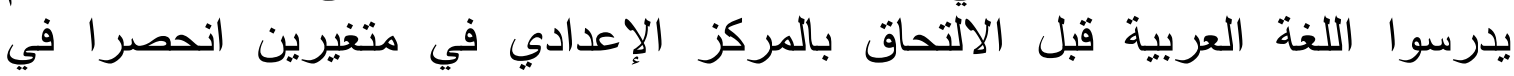

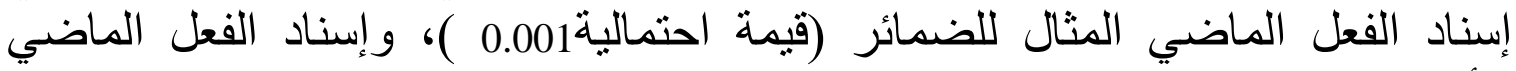

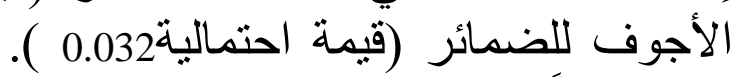

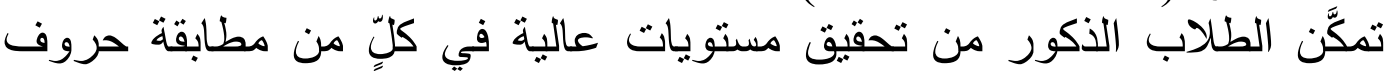

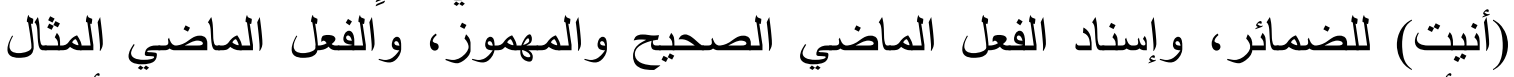
والأجوف للضمائر، بينما حققوا مستويات فوق الوسط في مطابقة حروف (أنيت) 
للضمائر مع أفعال تبدأ بحرف (التاء)، وصياغة المثنى. واستطاعت الإناث

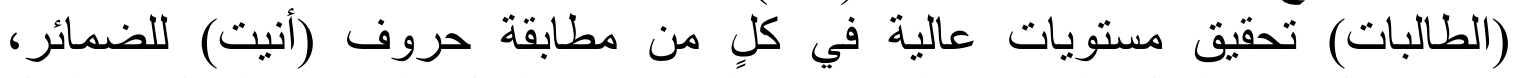

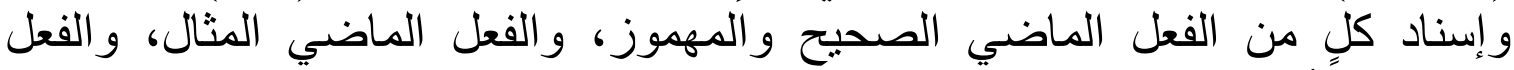
الماضي الأجوف للضمائر، ولّد جاءت مستوياتهن فوق الوسط في كلٍ من صبياغة المثنى دون تميُّز وفي بناء الفعل الماضي للمجهول الذي استطعن أن يتميَّزنَ فيه

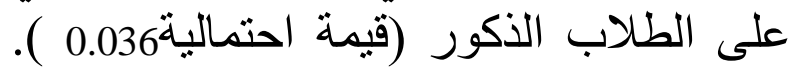
لقد إستطاع الطلاب المتخصيصون في اللغة الإنجليزية من تحقيق مستويات

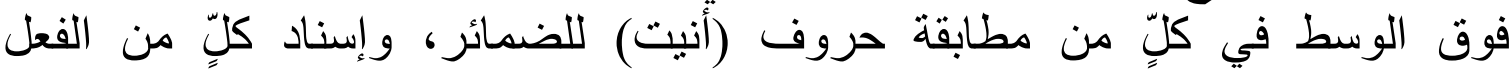

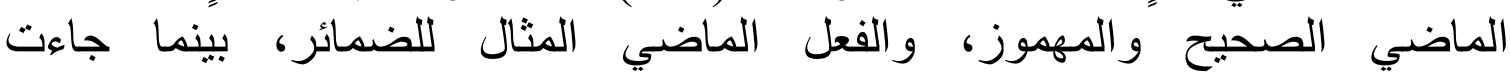
مستوياتهم في المتغيرات الأخرى جميعها دون الوسط وهي أقل المستويات بين التخصصات المختلفة، فيما عدا بناء الفعل الماضي، والفعل الفئل المضارع ل للمجهول، وصياغة اسم التفضيل.

لقد جاء مستوى الطلاب المتخصّصين في اللغة العربية فوق الوسط أيضاً

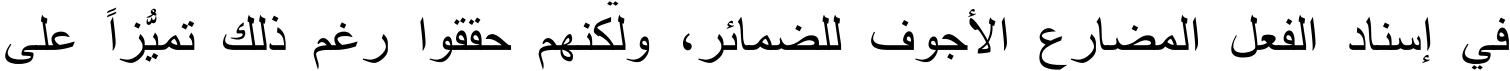

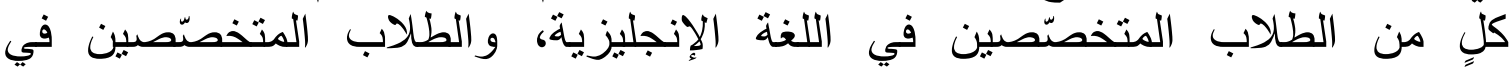
الثريعة (قيمة احتمالية 0.000 صفر لكليهما)، والطلاب المتخصئ الإنهين في في العلوم الإنسانية (قيمة احتمالية"0.021 )، كما جاء مستواهم فوق الوسط في صياغة أفعال

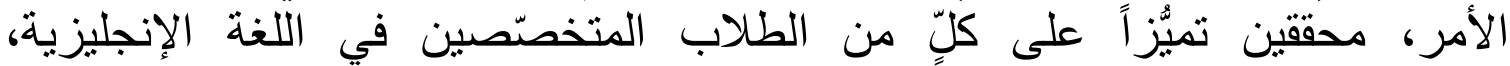
و المتخصيصين في العلوم الإنسانية و المتخصنصين في في الثريعة (قيمة احتمالية 0.000

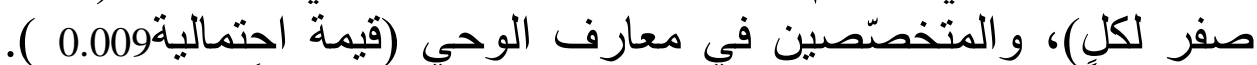

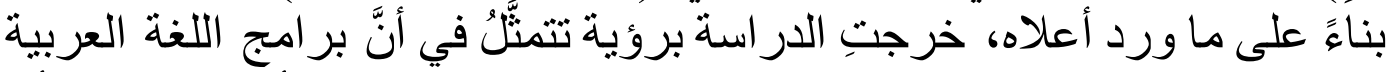

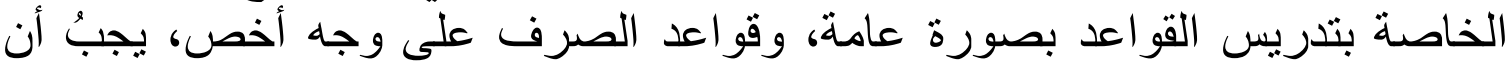

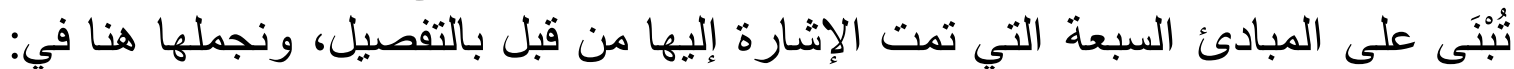

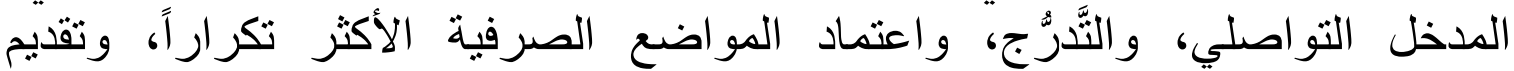

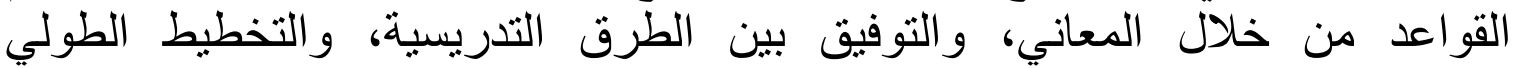
و الدائري للمادة الصرفية، وبناء الجسور المعرفية بين المؤسسات المعنية بتدريس اللغة العربية للناطقين بغير ها.

\section{المراجع}

Abdalla, A. E. (1996). An error analysis of the written Arabic of Malay students. [Ph.D thesis]. University of Malaya.

Adam, A. E. B. A. (1998). Arabic syntactic errors: An investigation into the written composition of Malay learners [Ph.D thesis]. University of Malaya.

Babbie, E. R. (1973). Survey research method. California Wadsworth Publishing Company.

Bell, J. (1999). Doing research: Your project a guide for first-time research in education and social science (3rd Ed). Open University Press.

Corder, S. P. (1988). Pedagogical grammar. In Grammar and second language teaching: A book of reading (pp. 123-143). Newbury House. 
Dornyei, Z. (2003). Questionnaires in second language research. Construction, administration and processing. Lawrance Erlbaum Associates Publisher.

Feng, S. (2004). Prosodic structure and it's implications for teaching Chinese as a second language. Journal of Chinese Language Teachers Association, 39(1), 1-24.

Mohamed, A.-M. M. (1991). Error-based interlinguistic comparisons, as learner-centered techniques of teaching English grammar to Arab students [Ph.D thesis]. University of Salford.

Raimes, A. (1983). Techniques in teaching writing. Oxford: Oxford University Press. Oxford University Press.

Schweigert, W. A. (1994). Research methods and statistics for psychology. Brooks \& Cole Publishing Company.

أبو عمشة، خالد حسين، و اللبدي، نزار راس2015 ـم ـمَن يَصلحُ أن يكون معلماً

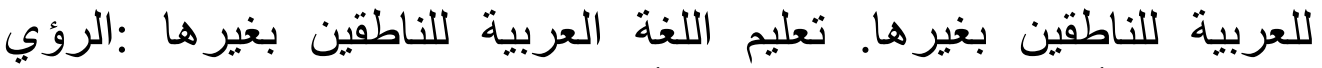

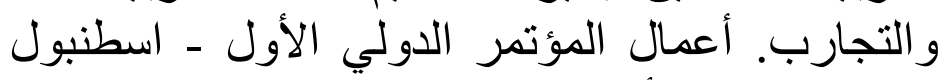

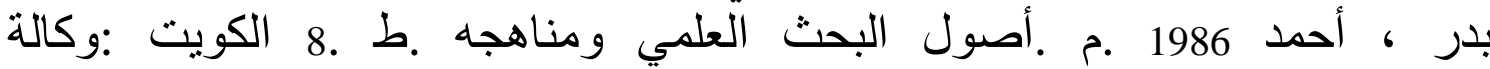
المطبو عات.

دليل الجامعة الإسلامية العالمية لعام 2002 م. كوالالمبور :الجامعة الإسلامية العالمية.

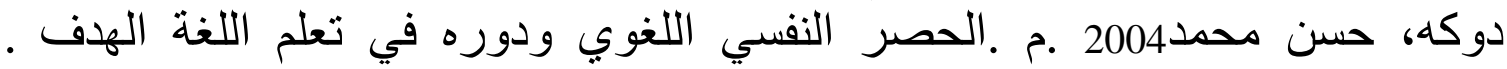

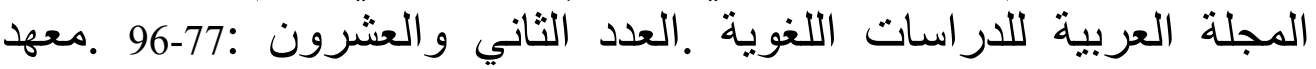

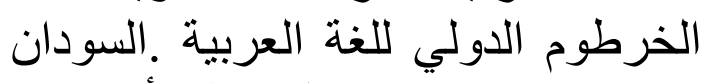

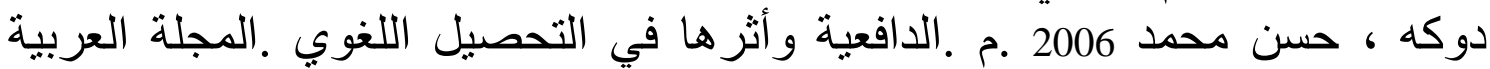

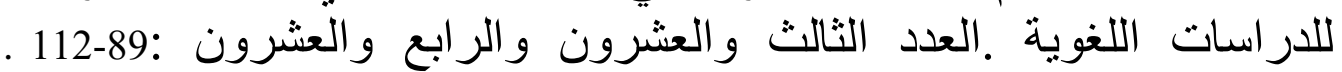

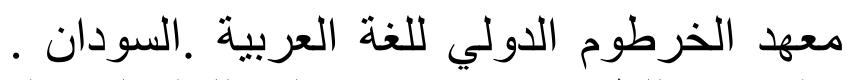

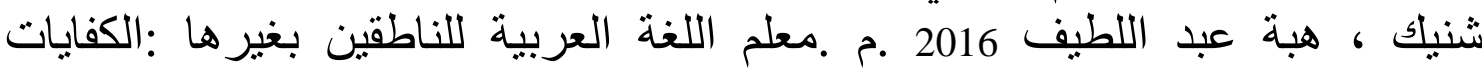
و المهار ات .شبكة الألوكة الأليكترونية.

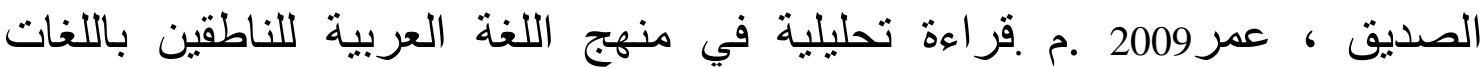

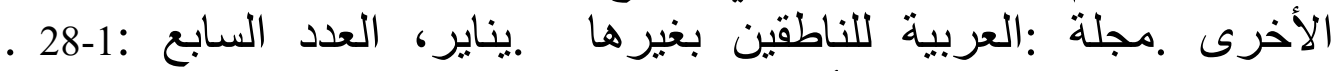

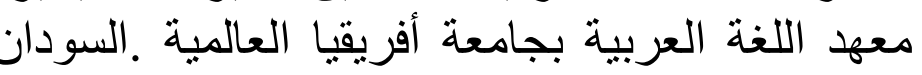

عبد السلام ، محمد 1960 .م .القياس النفسي والتربوي ـالقاهرة القدية :مكتبة النهضة المصرية.

عودة ، سليمان وسلكاوي ، فتحي حسن الإنس 1992 .م .أساسيات البحث العلمي في التربية و العلوم الإنسانية .اربد :مكتبة الكتاني.

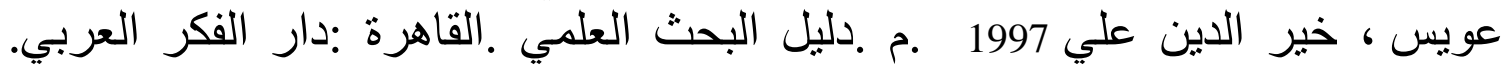

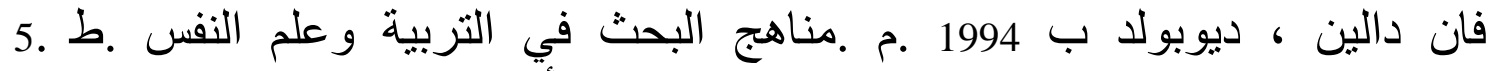
ترجمة محمد نبيل نوفل .القاهرة :مكتبة الأنجلومصرية.

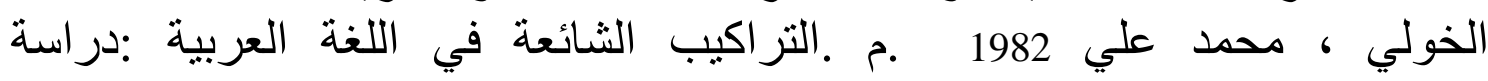
إحصائية .لبنان :مكتبة دار العلوم . 
قنديل ، محمود 1987 .م .مقدمة في المعالجة الإحصائية في البحث التربوي . الكويت :وزارة التربية مركز البحوث التربوية وحدة اللغة الإنجليزية.

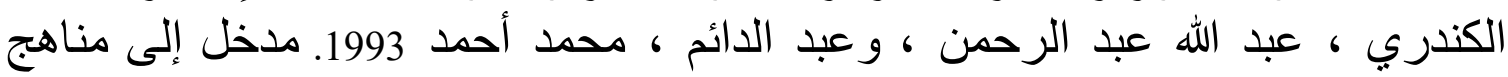
البحث العلمي في التربية و العلوم الإنسانية. الكويت وكئ :مكتبة الفلاح.

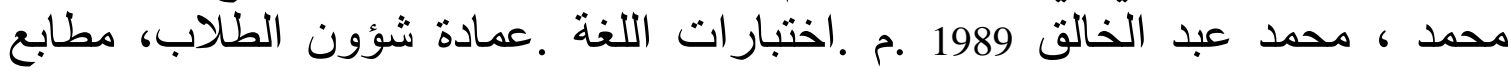
جامعة الملك سعود: الرياض. مرسي ، محمد منير 1994 .م .البحث التربوي وكيف نفهمه؟ .القاهرة :عالم الكتب.

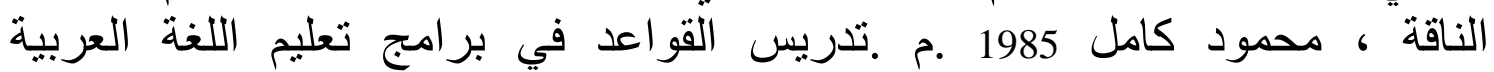

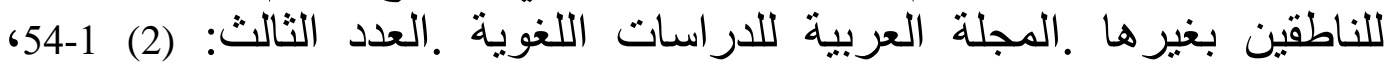

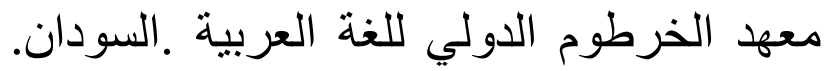
يس ، يس محمد وحسن محمد دوكة 2008 .م ـإشكالية ومنهاج قو اعد اللغة الهدف . مجلة :العربية للناطقين بغير ها ينائر ، العدد السادس :791-79 .معهد اللغة

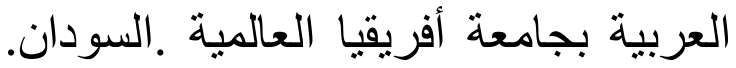
يس ، يس محمد وحسن محمد دوكة 2011 .م .قو اعد اللغة الثانية أو الأجنبية و التدريبات الثائعة (الأنواع و المسمبات والأنماط) .مجلة :العربية للناطقين

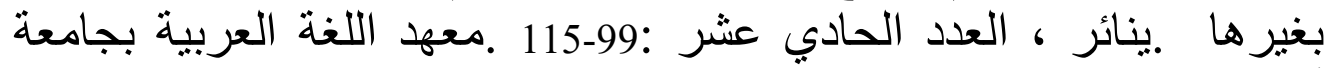

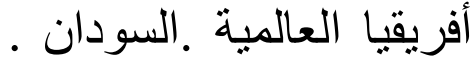

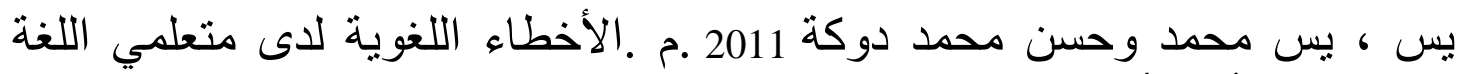

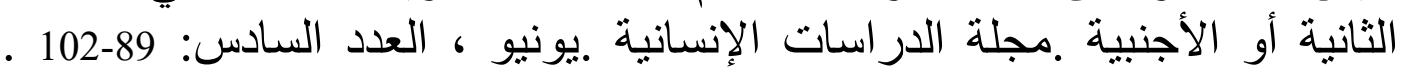

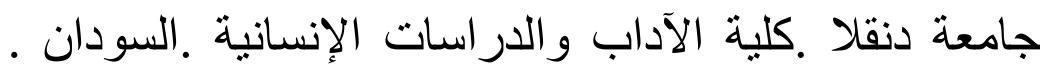


Yasin Mohamed Yasin, Hassan Mohamed Doka, Mauidlotun Nisa, Kawakib El-Nur Osman Measuring Malaysian Students Achievement Level in Arabic Morphology 